\title{
The biogeography and ecology of common diatom species in the northern North Atlantic, and their implications for paleoceanographic reconstructions
}

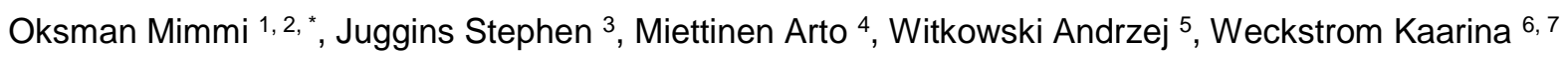

1 Univ Helsinki, Dept Geosci \& Geog, Gustaf Hallstromin Katu 2a, FIN-00014 Helsinki, Finland.

2 Aarhus Univ, Dept Geosci, Hoegh Guldbergs Gade 2, DK-8000 Aarhus C, Denmark.

3 Newcastle Univ, Sch Geog Polit \& Sociol, Newcastle Upon Tyne NE1 7RU, Tyne \& Wear, England.

${ }^{4}$ Fram Ctr, Norwegian Polar Inst, Hjalmar Johansens Gate 14, N-9296 Tromso, Norway.

5 Univ Szczecin, Palaeoceanol Unit, Nat Sci Res \& Educ Ctr, Fac Geosci, Mickiewicza 16a, Szczecin, Poland.

6 Univ Helsinki, Ecosyst \& Environm Res Programme, ECRU, Viikinkaari 1, FIN-00014 Helsinki, Finland.

7 Geol Survey Denmark \& Greenland GEUS, Dept Glaciol \& Climate, Oster Voldgade 10, DK-1350

Copenhagen, Denmark.

* Corresponding author : Mimmi Oksman, email address : mimmi.oksman@helsinki.fi

\begin{abstract}
:
Sound knowledge of present-day diatom species and their environments is crucial when attempting to reconstruct past climate and environmental changes based on fossil assemblages. For the North Atlantic region, the biogeography and ecology of many diatom taxa that are used as indicator-species in paleoceanographic studies are still not well known. Using information contained in large diatomenvironment calibration datasets can greatly increase our knowledge on diatom taxa and improve the accuracy of paleoenvironmental reconstructions. A diatom calibration dataset including 183 surface sediment samples from the northern North Atlantic was used to explore the distribution and ecology of 21 common Northern Hemisphere diatom taxa. We define the ecological responses of these species to April sea ice concentrations and August sea surface temperatures (aSSTs) using Huisman-Olff-Fresco (HOF)response curves, provide distribution maps, temperature optima and ranges, and high-quality light microscope images. Based on the results, we find species clearly associated with cold, warm and temperate waters. All species have a statistically significant relationship with aSST, and 15 species with sea ice. Of these, Actinocyclus curvatulus, Fragilariopsis oceanica and Porosira glacialis are most abundant at high sea ice concentrations, whereas Coscinodiscus radiants, Shionodiscus oestrupii, Thalassionema nitzschioides, Thalassiosira angulata, Thalassiosira nordenskioeldii and Thalassiosira pacifica are associated with low sea ice concentrations/ice-free conditions. Interestingly, some species frequently used as sea ice indicators, such as Fragilariopsis cylindrus, show similar abundances at high and low sea ice concentrations with no statistically significant relationship to sea ice.
\end{abstract}




\section{Highlights}

- A large diatom calibration dataset was used to explore the distribution and ecology of common North Atlantic diatom taxa. Ecological responses to August SST and April sea ice concentrations were defined. Caution needs to be taken with some commonly used sea ice indicator species.

Keywords : Diatoms, Calibration dataset, Northern hemisphere, Sea surface temperature, Sea ice 


\section{Introduction}

43 The need to better understand the impacts of the ongoing global warming imposes a demand for 44 paleoclimate records extending well beyond the instrumental era. These records can help us understand 
interactions between different components of the climate system and improve climate model projections of future impacts of climate warming. Paleoclimate research can help define baselines of natural climate change, thus helping us to set the recent observed changes in the long-term natural climate context. The demand for paleoclimate records is especially crucial in the Arctic region because of the amplified polar warming (e.g., Pithan and Mauritzen, 2014) and associated loss of Arctic sea ice during the last decades (Parkinson and Cavalieri, 2008; Parkinson, 2014; Kwok and Cunningham, 2015). Sea surface temperatures (SSTs) and sea ice concentrations are important parameters in northern high latitude paleoceanographic research, as SSTs strongly influence the Arctic sea ice extent, the stability of the Greenland Ice Sheet and climate of the northwest Europe (Holland et al., 2008; Årthun et al., 2016), whereas Arctic sea ice is a critical component of the climate system via regulating heat and moisture exchange between the ocean and the atmosphere, and via surface albedo feedbacks.

Marine fossil diatom assemblages are a widely used proxy for producing paleoceanographic and paleoclimatic records. Diatoms have a strong relationship to surface water hydrography and thus are excellent indicators of ocean surface conditions and variability of water masses. Diatoms are diverse and abundant at high latitudes and today, a large number of studies exist from various parts of the northern North Atlantic region: the Nordic Seas (Koç Karpuz and Schrader, 1990; Koç and Jansen, 1994; M iettinen et al., 2012), around Iceland (Jiang et al., 2001; 2002; 2005; 2015; Witak et al., 2005; M iettinen et al., 2011; Xiao et al., 2017), northern Svalbard (Koç et al., 2002; Oksman et al., 2017a), around Greenland (Andersen et al., 2004a; 2004b; Berner et al., 2008; 2011; Justwan et al., 2008; Justwan and Koç, 2009; Ren et al., 2009; M iettinen et al., 2015), Baffin Bay (Williams, 1986; 1990; 1993; Krawczyk et al., 2010; 2014; 2016; Sha et al., 2014; 2016; 2017; Oksman et al. 2017b) and the Labrador Sea (De Sève, 1999; Weckström et al., 2013; Pearce et al., 2014a). Some diatom species are associated with sea ice and this link has been used to reconstruct past sea ice variability (Justwan and Koç, 2008; Sha et al., 2014; 2016; 2017; M iettinen et al., 2015; Krawczyk et al., 2016). The earliest diatom-based reconstructions were conducted using qualitative diatom assemblage data (e.g., Williams, 1993; Witak et al., 2005; Krawczyk et al., 2010), but in the past few decades, the use (as well as the number) of calibration datasets, consisting of surface sediment diatom assemblages and associated measured environmental data for quantitative reconstructions of SST and sea ice, has increased remarkably (Koç Karpuz and Schrader, 1990; Jiang et al., 2001; 2005; Andersen et al., 2004a; Justwan and Koç, 2008; Sha et al., 2014; M iettinen et al., 2015; Krawczyk et al., 2016).

Although diatom calibration datasets have been used to reconstruct paleoceanographic and paleoclimate variability, the biogeography and especially the ecology of the common (key) taxa (i.e., the relations of these species to one another and to their environment) have largely remained undescribed, and literature on diatom ecology in the North Atlantic region is scarce (e.g., von Quillfeldt, 2000; 2001; Jiang et al., 2001; Andersen et al., 2004b; Pearce et al., 2014b; Krawczyk et al., 2014; 2016). Understanding the ecology and living environment of these indicator species is essential given the frequent use of diatom assemblage analysis in both quantitative and qualitative paleoceanographic reconstructions. The extensive spatial coverage and the large number of sites make large calibration datasets not only an excellent tool for paleoclimate reconstructions but provide also a highly useful platform for studying the ecology and biogeography of diatom taxa. This paper presents the most common diatom taxa in the northern North Atlantic calibration dataset and assesses their responses to the paleoclimatically important environmental parameters August SST (aSST) and April sea ice concentrations (aSIC). August and April have been found to be statistically the most significant months in explaining diatom assemblage distribution along SST and SIC gradients (Berner et al., 2008; M iettinen et al., 2015), thus aSST and aSIC are the most commonly used parameters in quantitative diatom-based paleoceanographic reconstruction. The aim of this study is to (1) 
present the geographical distribution of the common diatom species in the northern North Atlantic, (2) discuss the relationship between diatom species and two important environmental variables (SST and sea ice) and (3) present good-quality light-microscopy images of these species to aid with species identification.

\section{Materials and methods}

A diatom calibration dataset (Andersen et al., 2004a, 2004b; M iettinen et al., 2015) including 183 surface sediment samples (prepared for analysis using standard methodology, see Koç Karpuz and Schrader, 1990; Koç et al., 1993) and measured environmental data (SSTs and sea ice concentrations) around the North Atlantic, the Labrador Sea, the Nordic Seas and Baffin Bay (Fig. 1) was used in this study to examine the biogeography and ecology of common North Atlantic diatom taxa. The calibration dataset consists of 52 diatom species in total, of which we selected the 21 most common species based on their wide-ranging occurrence at high latitudes and their frequent use as paleoceanographic indicators in the northern North Atlantic and Arctic regions. However, some common North Atlantic taxa, such as Chaetoceros resting spores, Paralia sulcata, Fossula arctica and Fragilariopsis reginae-jahniae were not included in this study. Chaetoceros resting spores were not included in the dataset as they consist of several species with potentially different ecologies and they have shown negligible sensitivity to SST (Koç Karpuz and Schrader, 1990). Paralia sulcata was part of the original version of the calibration dataset (Koç Karpuz and Schrader, 1990), but was found to have too broad a temperature tolerance and was thus removed from the dataset by Andersen et al. (2004a). Fossula arctica and Fragilariopsis reginae-jahniae are sea-ice associated species which have only relatively recently been described (in 1996 and 2000, respectively) and were not included in the original calibration dataset. Hence, these species are not presented here as separate taxa but were, however, likely included in the total counts of Fragilariopsis oceanica (see discussion under individual species).

The 183 surface sediment samples in the calibration dataset cover the main areas of the North Atlantic between $42^{\circ} \mathrm{N}$ and $79^{\circ} \mathrm{N}$ (Fig. 1). The surface sediment samples were taken during multiple cruises from various water depths using either a box-corer or a multicorer. The sample location, sampling year, water depth and modern August SST and April sea ice data are compiled into Appendix 1. Every surface sediment sample represents the uppermost $1 \mathrm{~cm}$ of the sediment, and all the samples were visually verified to represent the topmost sediment layer. The majority of the samples (80) were collected before the 1990s and were part of the original calibration dataset by Koç Karpuz and Schrader (1990). Later, 57 samples, collected between the years 1990-2000, were added by Birks and Koç (2002) and 46 samples, collected between 2006-2008, were added by M iettinen et al. (2015). Diatom concentrations ( $10^{6}$ valves/g dry sediment) for the first 137 samples are presented in Koç Karpuz and Schrader (1990) and Birks (2001), whereas for the remaining 46 samples concentrations have not been analyzed. 


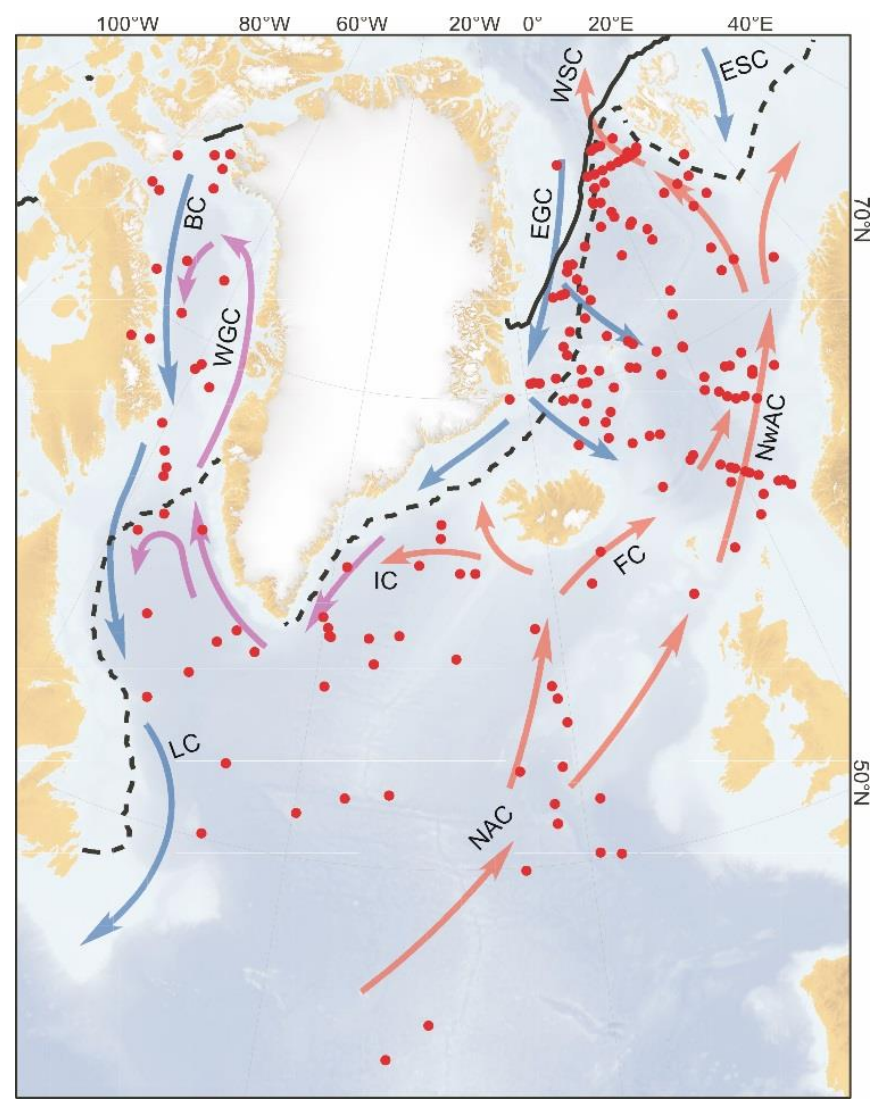

Figure 1. Map of the northern North Atlantic showing locations of the 183 surface sediment samples in the North Atlantic diatom calibration dataset, the main surface ocean currents and sea ice extent. M edian sea ice extent over the years 1981-2010: winter maximum ( $M$ arch) is shown as a dashed line and summer minimum (September) as a full line (Fetterer et al., 2017). Warm ocean currents are presented with red arrows, cold currents with blue arrows and temperate water currents with purple arrows. NAC=North Atlantic Current, NwAC=Norwegian Atlantic Current, $\mathrm{FC}=$ Faroes Current, $\mathrm{ESC}=$ East Spitsbergen Current, WSC $=$ West Spitsbergen Current, EGC $=$ East Greenland Current, IC=Irminger Current, WGC $=$ West Greenland Current, $B C=$ Baffin Current, $L C=$ Labrador Current.

The modern environmental data associated with each surface sediment sample was gathered from the World Ocean Atlas 2001 for August SSTs, including all observations since the year 1900 (Stephens et al., 2002). Satellite data for the modern April sea ice data was compiled from the National Snow and Ice Data Center (NSIDC, www.nsidc.com; Cavalieri et al. 1996) using data between years 1979-1999 for samples collected before 2000, and years 1979-2006, 1979-2007 and 1979-2008 for the samples taken in 2006, 2007 and 2008, respectively (M iettinen et al., 2015).

The temperature ranges of each species are based on the occurrence of the species in the surface sample dataset. The surface sample associated with the coldest modern temperature of the dataset, which includes a given species determines the minimum temperature for this species. Correspondingly, the sample associated with the warmest measured SST defines the warmest temperature for the species. Note that the temperature range of the data set is $0-20^{\circ} \mathrm{C}$. The temperature optimum for each species was calculated from the dataset using the weighted averaging method (WA, ter Braak and Looman, 1986). We would like to emphasize that species' optima are always defined by the temperature range of the calibration dataset and should not be taken as absolute values. The distribution maps are based on the relative abundance of the species in the surface sediment samples (percentage of diatom valves based on total counted valves (minimum of 300 valves). The counted valves in the dataset include the 52 species which were found to have 
152 a statistically significant response to temperature (Koç Karpuz and Schrader, 1990; Birks and Koç, 2002;

153 Andersen et al., 2004b).

The type and significance of the response of each taxon to SST and sea ice concentration was assessed by fitting a series of Huisman-Olff-Fresco (HOF) hierarchical response models (Huisman et al., 1993) following Jansen and Oksanen (2013). This procedure fits seven models of increasing complexity, from a null model or flat response (i.e., no relationship, model I), through monotone sigmoid (II), monotone sigmoid with plateau (III), unimodal symmetric (IV), unimodal skewed (V), bimodal with equal peaks (VI) and bimodal with unequal peaks (VII), and selects the most parsimonious model using Akaike information criterion corrected for small sample size (AICC) and a bootstrap approach (500 permutations) to ensure model stability. Taxa are deemed to have a statistically significant relationship to either SST or sea ice concentration if the selected response yields statistically significant improvement in fit over a null or flat model. All numerical analyses were performed using the R 3.4.1 software for statistical computing (R Core Team, 2017) with the package eHOF (Jansen and Oksanen, 2013).

Q-mode factor analysis (Imbrie and Kipp, 1971) was applied to the surface sediment diatom data to investigate the distribution of distinct diatom assemblages in the surface sediment dataset. This analysis has been applied to the earlier version of this calibration dataset (Koç Karpuz and Schrader, 1990; Andersen et al., 2004b), and shows the distribution of eight factors (composition of diatom assemblages related to distinct water masses): Greenland Arctic Waters, North Atlantic Current, Sub-Arctic Waters, Norwegian Atlantic Current, M arginal Ice Zone (renamed from Sea Ice assemblage in Oksman et al. 2017b), Arctic Waters, EastWest Greenland Current and M ixed Water M asses (Fig. 2). 


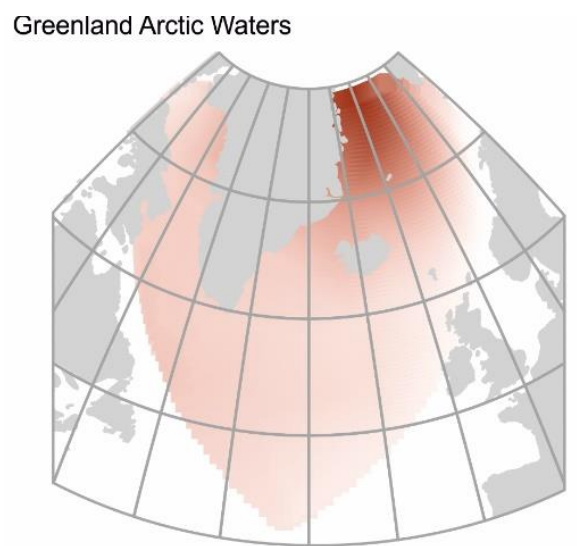

Sub-Arctic Waters

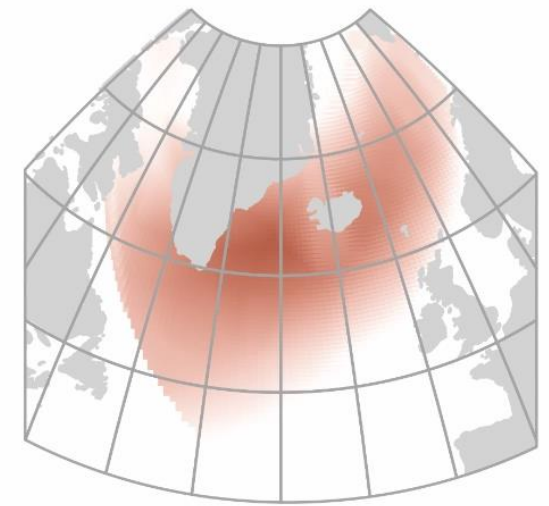

Marginal Ice Zone

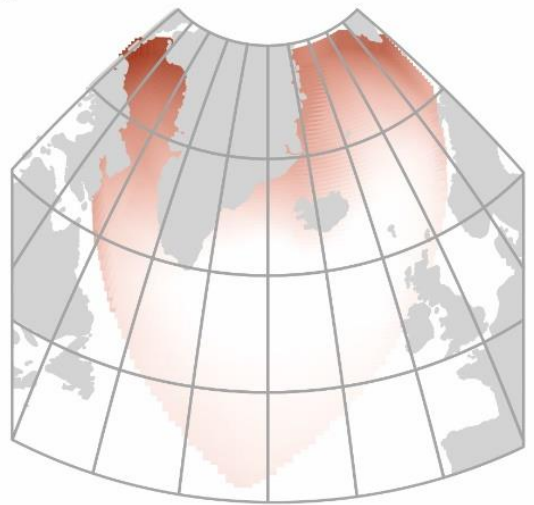

East-West Greenland Current

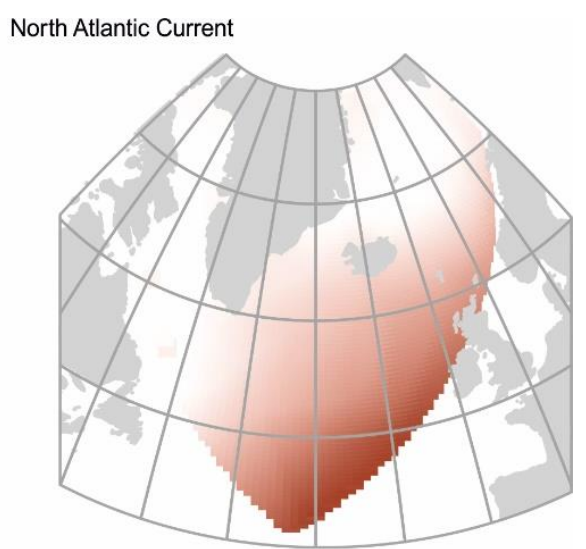

Norwegian Atlantic Current

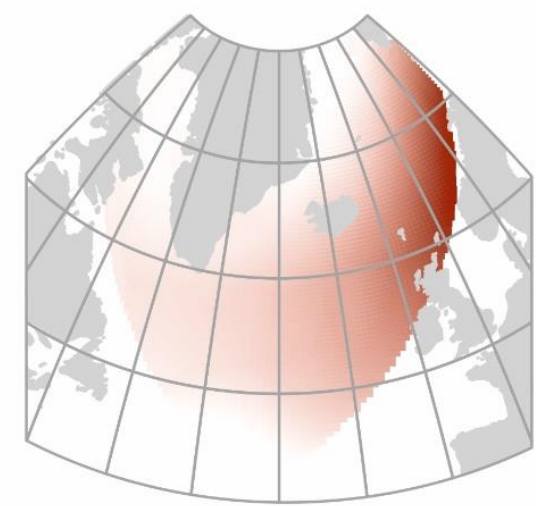

Arctic Waters

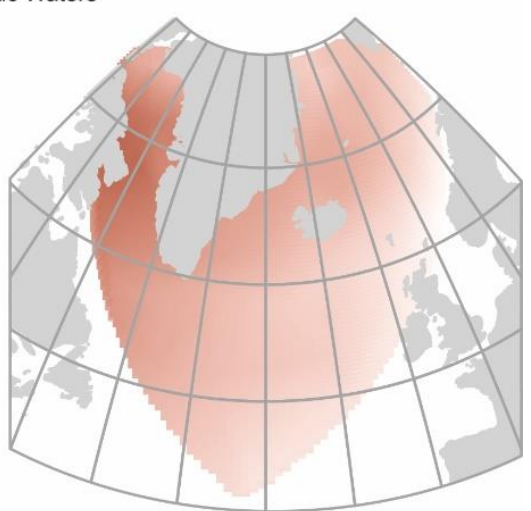

Mixed Water Masses

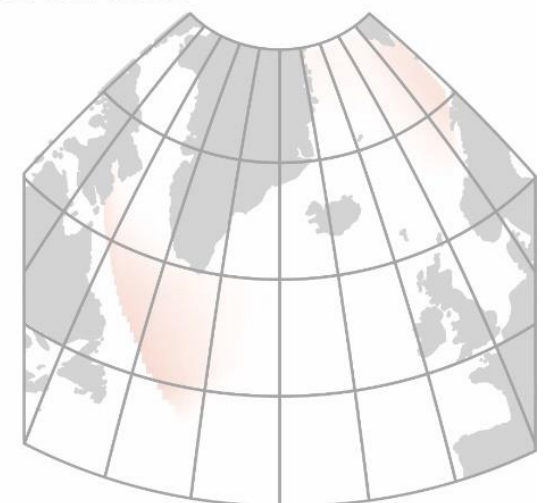

Figure 2. Geographical distribution of the eight factor assemblages discussed in the individual species descriptions (Greenland Arctic Waters, North Atlantic Current, Sub-Arctic Waters, Norwegian Atlantic Current, Marginal Ice Zone, Arctic Waters, East-West Greenland Current and Mixed Water Masses) frequently referred to in the text. The distribution of each factor assemblage is represented in red, i.e., stronger red shading referring to higher loadings of 
the factor assemblage. These factors are the same as in Andersen et al. (2004b) but are based on an extended number of surface sediment samples compared to Andersen et al. (2004b).

181

Photomicrographs of diatom species were taken using diatom microscope slides prepared from the downcore sediment samples (core M D99-2322 from southeast Greenland, core SL-170 from Baffin Bay and core AI07-14G from southeast Newfoundland) using a Zeiss Axiolmager.M2 upright light microscope with 1000x magnification and an AxioCam M Rc5 digital camera. Diatom slides were prepared according to Koç Karpuz and Schrader (1990) and mounted with Naphrax that has a refractive index of 1.73. The given key taxonomic literature is based on references that are widely used and easily available.

\section{Results}

The diatom taxa presented here include species from 10 different genera, the most common of which is Thalassiosira with 9 species. Other common genera are Coscinodiscus, Fragilariopsis and Rhizosolenia. The most common species in the calibration dataset are Thalassiosira gravida, Thalassiothrix longissima, Rhizosolenia hebetata f. semispina, Actinocyclus curvatulus, Thalassiosira antarctica var. borealis resting spore and Shionodiscus trifultus, which were present in more than $85 \%$ of the surface samples. Species that generally were found at high abundances were Thalassiosira gravida, Rhizosolenia hebetata f. semispina, Thalassiosira antarctica var. borealis resting spore and Fragilariopsis oceanica (abundances on average between 8 and $14 \%$ ). The geographical distribution, temperature range, August SST optima and ecological response curves to August SSTs and April sea ice concentrations of the diatom taxa are listed below and summarized in Table 1. Diatom species are presented with their basionym and synonyms, light-microscopy images and references to easily accessible key literature.

Table 1. aSST optimum, minimum and maximum, and response model types (I) a null model or flat response (i.e., no relationship), (II) through monotone sigmoid, (III) monotone sigmoid with plateau, (IV) unimodal symmetric, (V) unimodal skewed, (VI) bimodal with equal peaks and (VII) bimodal with unequal peaks to aSST $\left({ }^{\circ} \mathrm{C}\right)$ and April sea ice for the 21 studied diatom taxa. 


\begin{tabular}{lcccccc}
\hline Species & SST optimum & min. SST & max. SST & $\begin{array}{c}\text { Response to } \\
\text { SIC }\end{array}$ & \multicolumn{2}{c}{ Response model type } \\
& & & & SST & SIC \\
\hline Actinocyclus curvatulus & 4.7 & 0 & 15.2 & Yes & V & II \\
Bacterosira bathyomphala spore & 4.6 & 1 & 13.2 & No & IV & I \\
Coscinodiscus marginatus & 7.1 & 1.6 & 15.7 & No & IV & I \\
Coscinodiscus oculus-iridis & 6.1 & 1.7 & 14.4 & Yes & IV & VII \\
Coscinodiscus radiatus & 10.0 & 1.6 & 19.7 & Yes & IV & II \\
Fragilariopsis cylindrus & 4.4 & 0 & 13.2 & No & IV & I \\
Fragilariopsis oceanica & 3.6 & 0 & 13.1 & Yes & II & V \\
Porosira glacialis & 4.3 & 0 & 13.4 & Yes & V & V \\
Rhizosolenia hebetata f. hebetata & 5.1 & 1.3 & 15.2 & No & IV & I \\
Rhizosolenia hebetata f. semispina & 8.5 & 1.3 & 18.9 & Yes & IV & II \\
Shionodiscus oestrupii & 13.4 & 2.8 & 19.7 & Yes & III & II \\
Shionodiscus trifultus & 4.4 & 2.5 & 15.2 & No & V & I \\
Thalassionema nitzschioides & 11.1 & 1.3 & 19.7 & Yes & V & II \\
Thalassiosira angulata & 9.1 & 2.0 & 15.5 & Yes & IV & VII \\
Thalassiosira anguste-lineata & 4.0 & 0 & 15.5 & Yes & V & V \\
Thalassiosira antarctica var. borealis spore & 4.9 & 0 & 19.7 & No & IV & I \\
Thalassiosira gravida & 7.1 & 0 & 18.9 & Yes & IV & II \\
Thalassiosira hyalina & 4.7 & 0 & 11.9 & Yes & IV & VII \\
Thalassiosira nordenskioeldii & 7.1 & 1 & 13.2 & Yes & V & II \\
Thalassiosira pacifica & 9.0 & 2.4 & 13.2 & Yes & IV & II \\
Thalassiothrix longissima & 8.6 & 1 & 19.7 & Yes & IV & II
\end{tabular}
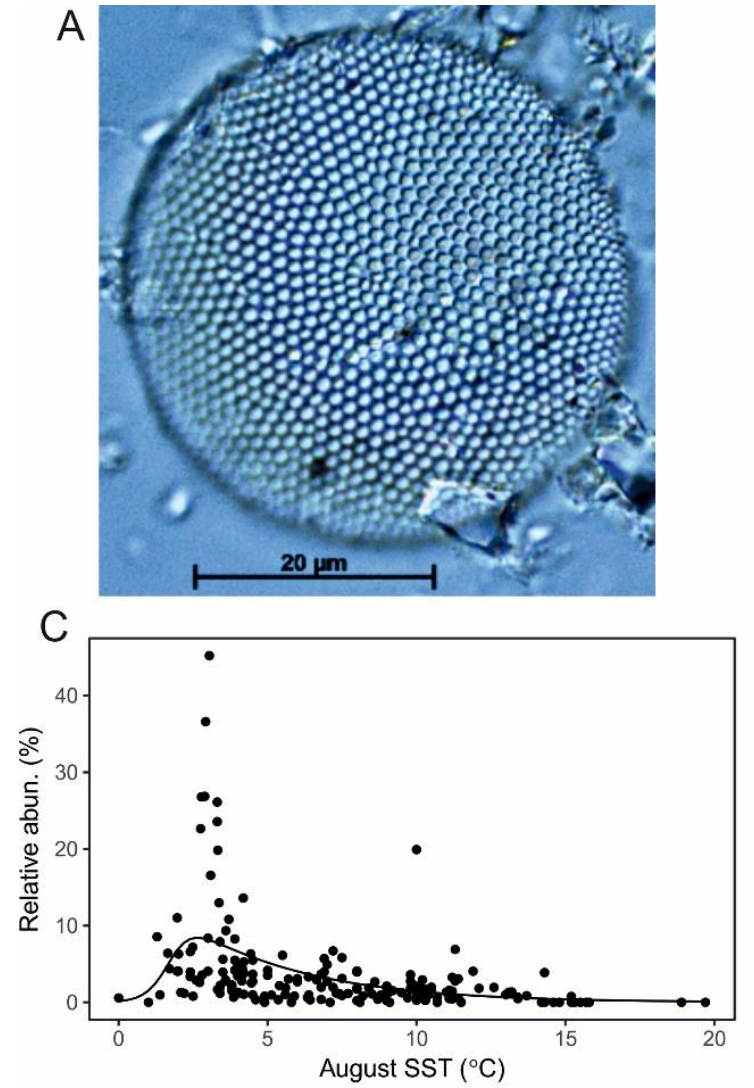

B
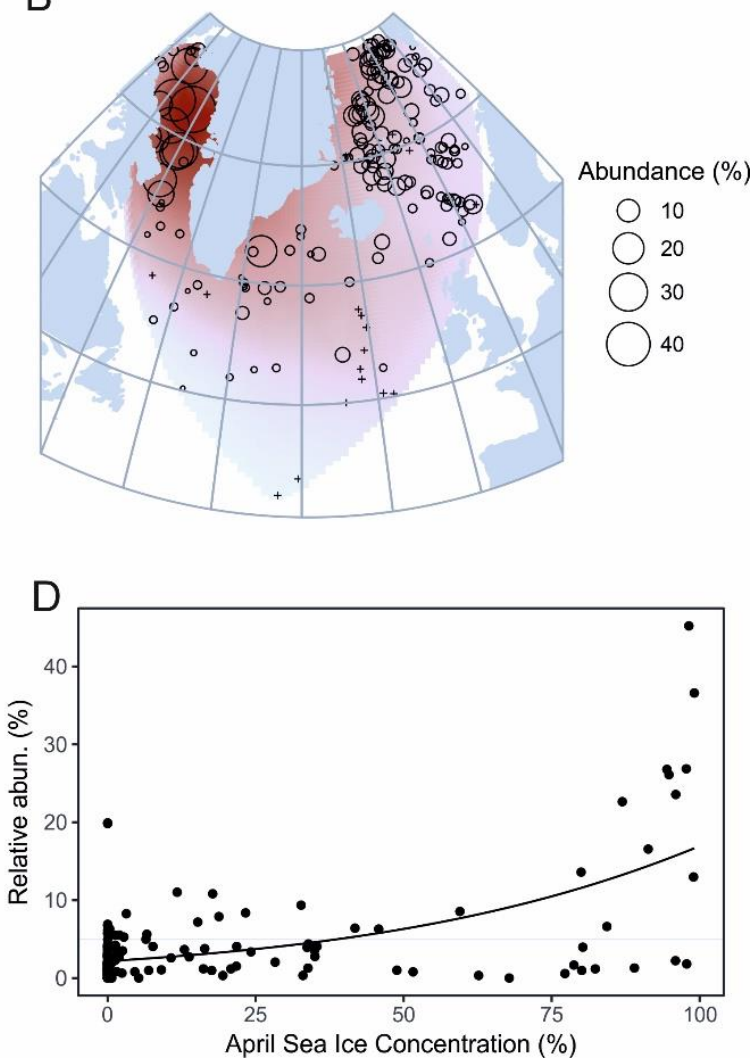
Figure 3. Actinocyclus curvatulus. a) Light microscopy image of the species (sample from Baffin Bay, core SL-170), b) Geographical distribution (dark red shading indicates where abundances are highest, and symbol + refers to location with 0 abundances), c) Response to August SST, d) Response to April sea ice concentrations.

Actinocyclus curvatulus Janisch in A. Schmidt (Fig. 3)

221 Synonyms. Coscinodiscus curvatulus var. subocellatus Grunow, Actinocyclus subocellatus (Grunow) Rattray.

References. Hasle and Syvertsen, 1996, p. 121, pl. 19; Sancetta, 1982, p. 222, pl. 1, figs. 1-3; Jensen, 2003, p. 110, pl. 1, figs. 4-7; Scott and Thomas, 2005, p. 52, figs. 2.23a-d; Pearce et al., 2014b, p. 444, fig. 4.

Response to environmental gradients. Statistically significant relationship to both SST and sea ice. Temperature range from 0 to $15.2^{\circ} \mathrm{C}$, optimum $4.7^{\circ} \mathrm{C}$. Highest abundances are found when sea ice concentrations are above $80 \%$ (Fig. 3d).

Distribution. In the North Atlantic, Actinocyclus curvatulus is most abundant ( $>40 \%$ of total assemblages) in the Baffin Bay and Nares Strait region (north of $65^{\circ} \mathrm{N}$ ), however, it also occurs at relatively high abundances ( $>30 \%$ of total assemblages) in the Nordic Seas and Fram Strait. The species is rare south of $60^{\circ} \mathrm{N}$. Actinocyclus curvatulus is described as a cold, bipolar species found from both Arctic and Antarctic waters (Hasle and Syvertsen, 1996). It is an important contributor to the Arctic Water assemblage (Fig. 2; Andersen et al., 2004b) as it occurs at high abundances under the East Iceland Current and the Jan M ayen Polar Current and along the Sub-Arctic front (Fig. 2; De Sève, 1999; Jiang et al., 2001; Andersen et al., 2004b), yet the highest abundances of Actinocyclus curvatulus in the calibration dataset are found in Baffin Bay (Fig. 3b). The species can be defined as a "low SST - high sea ice concentration" indicator (Fig. 3c, d). Based on modern observational data, Actinocyclus curvatulus is a marginal ice zone (M IZ) species, blooming in the cold and fresher meltwater layer near the sea ice margin (von Quillfeldt et al., 2003). In Baffin Bay, Actinocyclus curvatulus has been (together with Shionodiscus trifultus) grouped into the "Summer Pack Ice" assemblage, representing heavy summer pack ice and also possibly indicating the Arctic/subarctic oceanographic 241 boundary (Williams, 1986; 1990). 
A
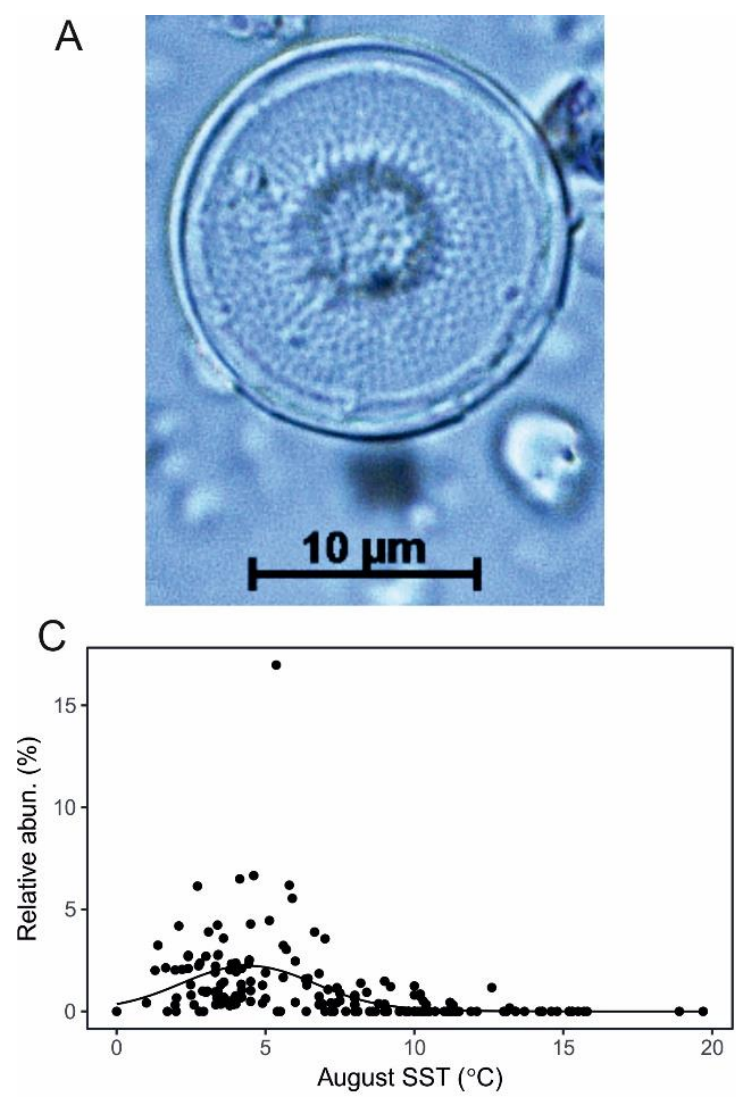

B

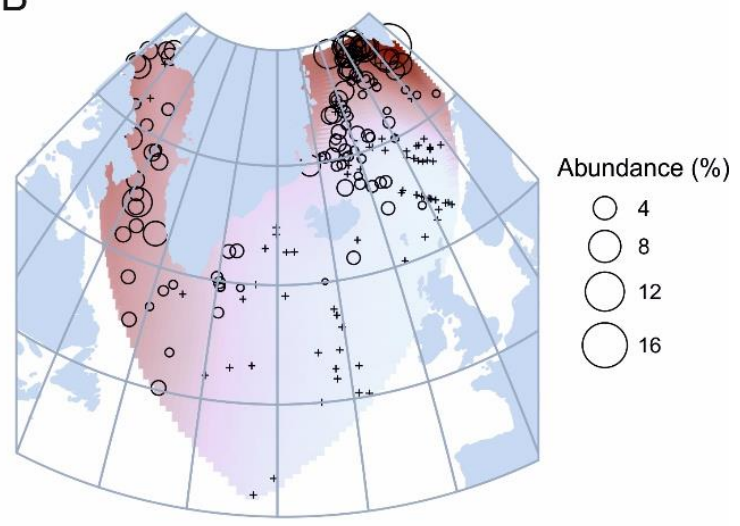

D

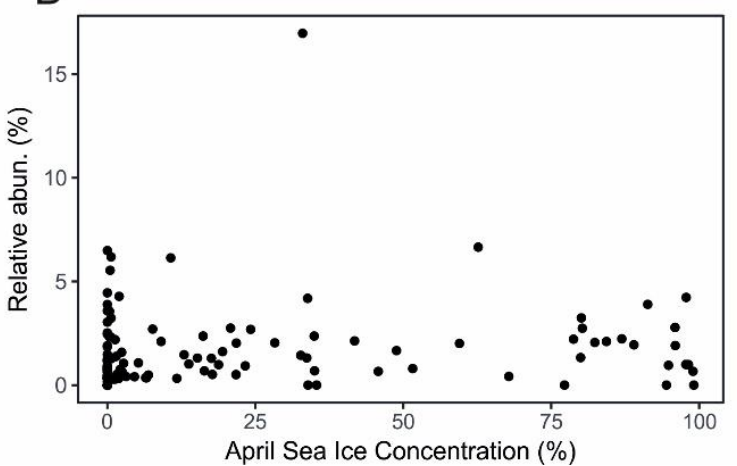

Figure 4. Bacterosira bathyomphala spore. a) Light microscopy image of the species (sample from Baffin Bay, core SL170), b) Geographical distribution (dark red shading indicates where abundances are highest, and the symbol + refers to location with 0 abundances), c) Response to August SST, d) Response to April sea ice concentrations.

\section{Bacterosira bathyomphala spore (Fig. 4)}

Basionym. Coscinodiscus bathyomphalus Cleve.

Synonyms. Lauderia fragilis Gran; Bacterosira fragilis (Gran) Gran.

References. Sancetta, 1982, p. 227, pl. 2, figs 1-4; Hasle and Syvertsen, 1996, p. 31, pl. 1; Cremer, 1998, p. 15, pl. 3, figs. 4-5; Bérard-Therriault et al., 1999, p. 18, pl. 1, figs a-c; Jensen, 2003, p. 112, pl. 2, figs. 3-5; Pienitz et al., 2003, p.23, pl. 6, fig. 14; Pearce et al., 2014b, p. 444, figs. 5-8.

Response to environmental gradients. Statistically significant relationship to SST, but not to sea ice. Temperature range from 1 to $13.2^{\circ} \mathrm{C}$, optimum $4.6^{\circ} \mathrm{C}$ (Fig. $4 \mathrm{C}$ ).

Distribution. The highest abundances ( $>16 \%$ of the total assemblages) are found off SW Svalbard and the species is relatively common (ca. $10 \%$ of the total assemblages) in Fram Strait (north of $70^{\circ} \mathrm{N}$ ), along the East Greenland Current and in Nares Strait, western Baffin Bay and northern Labrador Sea (following the BaffinLabrador Current). It's rare along the Norwegian margin and south of $60^{\circ} \mathrm{N}$.

The response to SST in our study agrees well with previous literature, where Bacterosira bathyomphala (including the spore) is described as a sea ice-related species, typically found in Arctic-subarctic cold-water regions (Koç and Jansen, 1994; Hasle and Syvertsen, 1996; Andersen et al., 2004b; Krawczyk et al., 2010; 2013; Caissie, 2012). Modern observational data defines Bacterosira bathyomphala as a typical early spring bloomer (von Quillfeldt, 2000) and an important member of the Sea Ice/ M arginal Ice Zone assemblage (Fig. 2; Andersen et al. 2004b). The response of the taxon based on the large calibration dataset used in this study shows that it can occur at similar abundances $(<5 \%)$ at both low and high sea ice concentrations (Fig. $4 d$ ) showing that while this taxon is a good cold-water indicator, it cannot be used as an indicator of sea ice presence. 
A
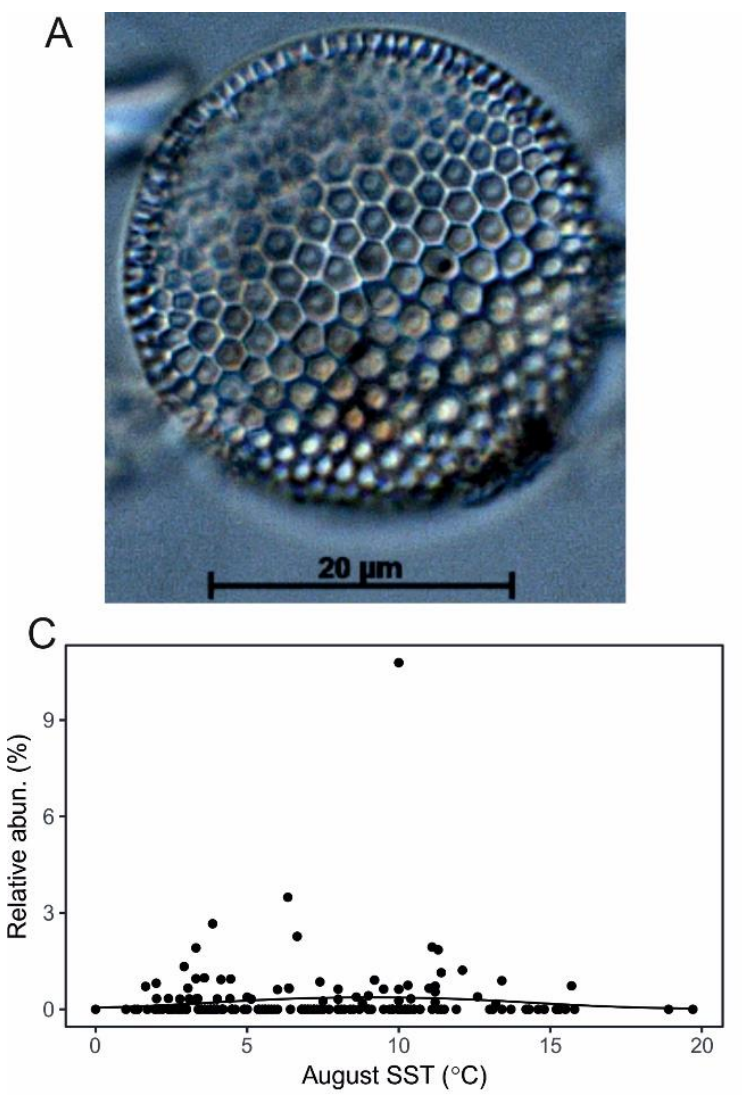

B
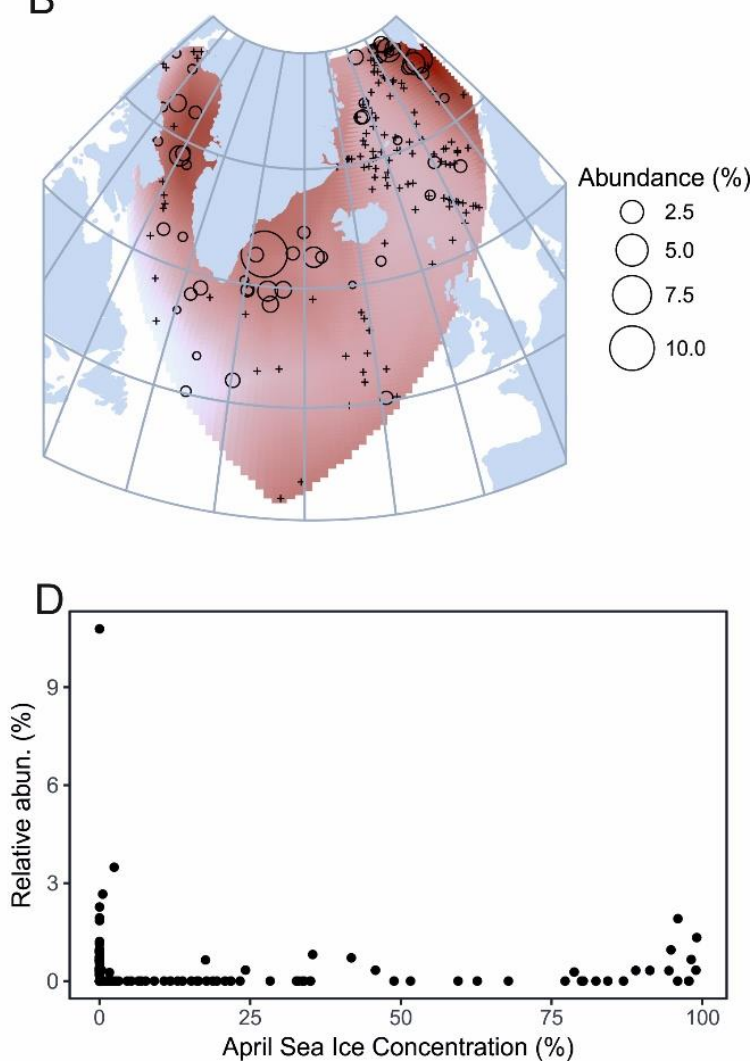

Figure 5. Coscinodiscus marginatus. a) Light microscopy image of the species (sample from Baffin Bay, core SL-170), b) Geographical distribution (dark red shading indicates where abundances are highest, and symbol + refers to location with 0 abundances), c) Response to August SST, d) Response to April sea ice concentrations.

Coscinodiscus marginatus Ehrenberg (Fig. 5)

References. Sancetta, 1982, p. 228, pl. 2, fig. 10; Hasle and Syvertsen, 1996, p. 107, pl. 18; Scott and Thomas, 2005, p. 43, fig. 2.18b.

Response to environmental gradients. Temperature range from 1.6 to $15.7^{\circ} \mathrm{C}$, optimum $7.1^{\circ} \mathrm{C}$. Statistically significant relationship to SST, but not to sea ice (Fig. 5c, d).

Distribution. Coscinodiscus marginatus is not a common species in the calibration dataset and generally shows low abundances (mostly $\measuredangle \%$ of the total assemblage). In the studied dataset, it was present in 51 surface samples (out of 183), and the highest abundances are found in SE Greenland, SW Svalbard and Baffin Bay.

Coscinodiscus marginatus is described as a cosmopolitan species occurring in temperate to warm waters (Hasle and Syvertsen, 1996). In the Labrador Sea, it is reported to dominate the North Atlantic assemblage that has strong Atlantic water influence (De Sève, 1999). In the North Pacific it occurs north of the Subarctic 288 Front in the open North Pacific $\left(10-14{ }^{\circ} \mathrm{C}\right)$, where it is rare apart from the north-eastern part (Sancetta, 1982; Ren et al., 2014). 
A
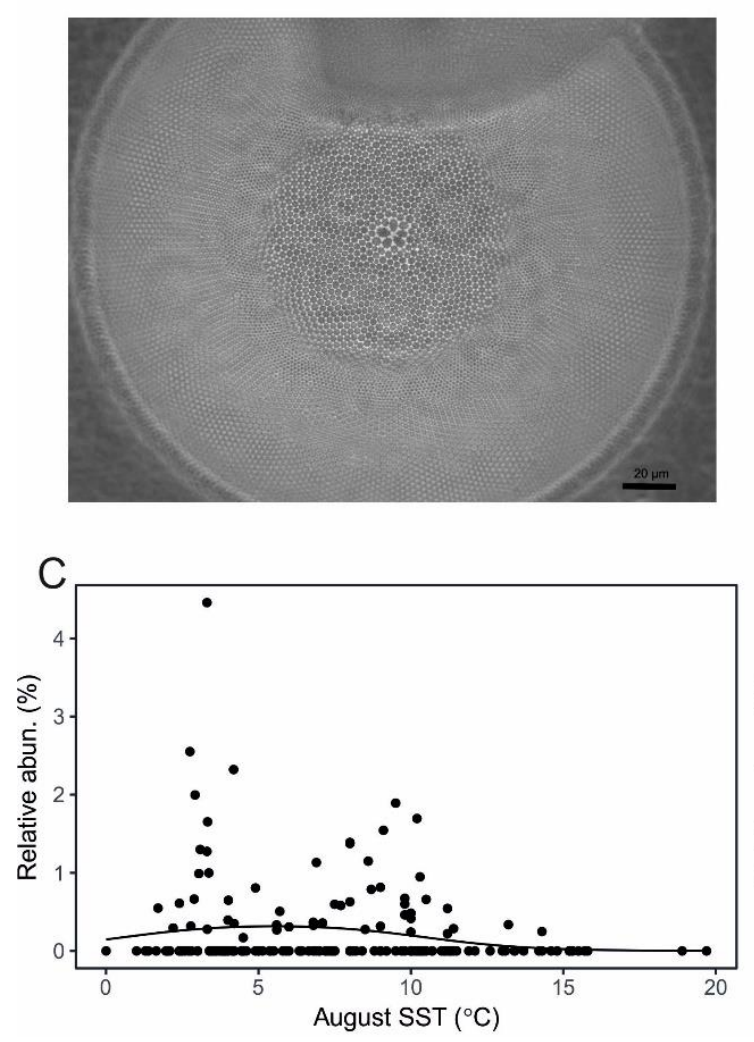

B
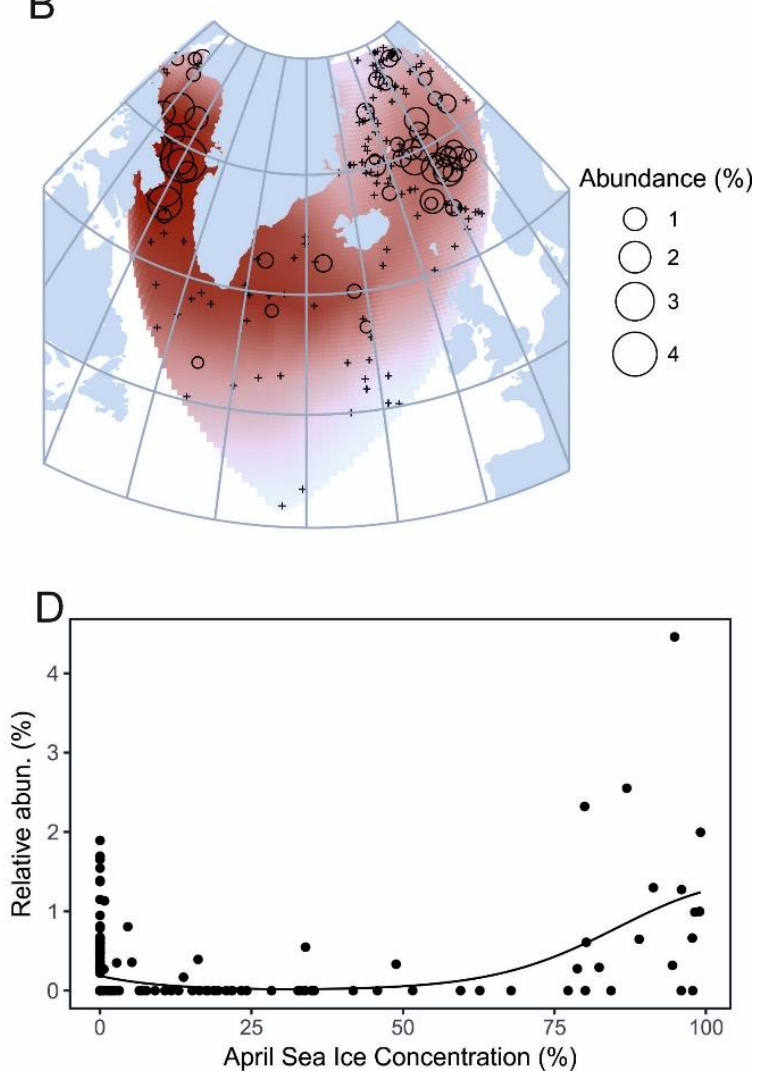

Figure 6. Coscinodiscus oculus-iridis. a) Light microscopy image of the species (sample from Newfoundland, core Al07$14 G$ ), b) Geographical distribution (dark red shading indicates where abundances are highest, and symbol + refers to location with 0 abundances), c) Response to August SST, d) Response to April sea ice concentrations.

Coscinodiscus oculus-iridis Ehrenberg (Fig. 6)

Basionym. Coscinodiscus radiatus var. oculus-iridis Ehrenberg

Synonym. Coscinodiscus oculus-iridis var. genuina Grunow, Coscinodiscus oculus-iridis var. typicus CleveEuler.

References. Sancetta, 1982, p. 229, pl. 2, fig. 11; Cremer, 1998, p. 21, pl. 7, fig. 1; Scott and Thomas, 2005 p. 44, fig. 2.18c.

Response to environmental gradients. Temperature range from 1.7 to $14.4^{\circ} \mathrm{C}$, optimum $6.1^{\circ} \mathrm{C}$. Statistically significant relationship to both SST and sea ice. Highest abundances are found at low SSTs and sea ice concentrations of $75-100 \%$ (Fig. 6d).

Distribution. Although Coscinodiscus oculus-iridis is a relatively common species in the studied dataset, it is found at low relative abundances $(<4 \%)$. It occurs at similar abundances also in the northern Pacific (Ren et al., 2014). The taxon has its highest abundances in Baffin Bay and in the Nordic Seas (between ca. 67 and $70^{\circ} \mathrm{N}$ ). It is also found in SE Greenland and Nares Strait.

In the North Atlantic, Coscinodiscus oculus-iridis is rare south of $60^{\circ} \mathrm{N}$. Its response to sea ice is bimodal (with unequal peaks): while the highest abundances are reached at high sea ice concentrations, the species reaches up to $2 \%$ (relative abundances) in areas not exhibiting sea ice. Such a bi-modal distribution may point towards different varieties within the species. 

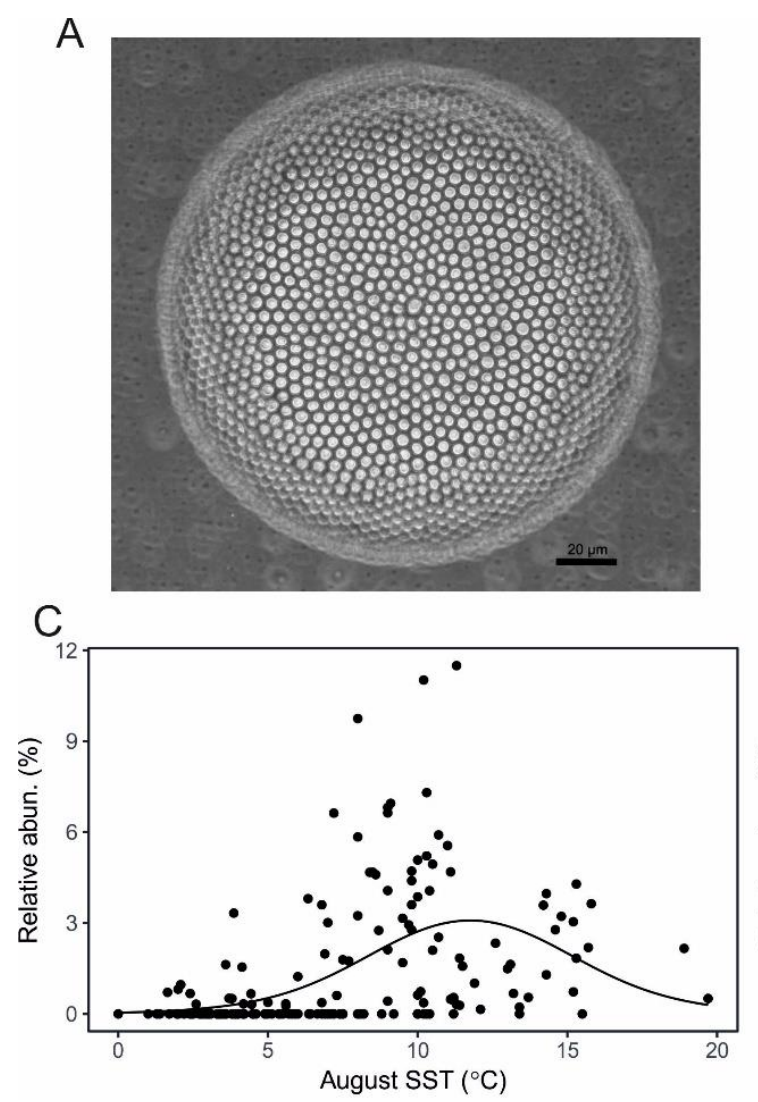

B
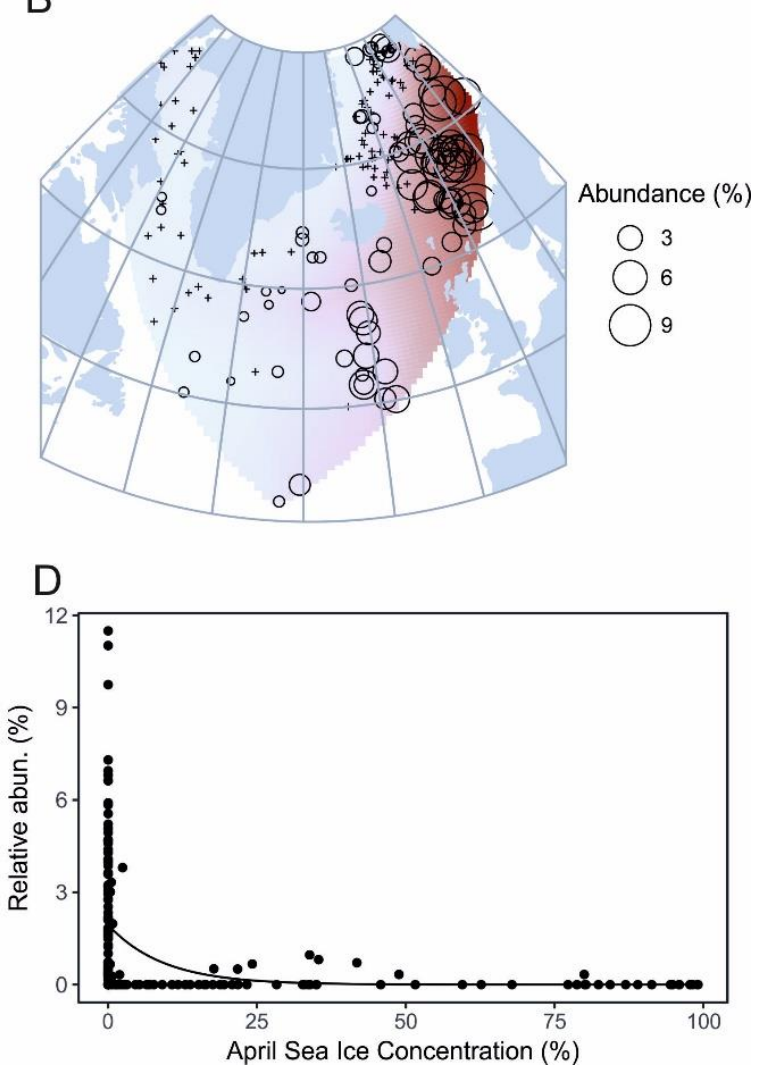

Figure 7. Coscinodiscus radiatus. a) Light microscopy image of the species (sample from Newfoundland, core AI07-14G), b) Geographical distribution (dark red shading indicates where abundances are highest, and symbol +refers to location with 0 abundances), c) Response to August SST, d) Response to April sea ice concentrations.

\section{Coscinodiscus radiatus Ehrenberg (Fig. 7)}

References. Hasle and Syvertsen, 1996, p. 107, pl. 18, figs. 6d-e; Snoeijs and Vilbaste, 1994, p. 32, pl. 120; Bérard-Therriault et al., 1999, p. 30, pl. 13d-e, 14a-c; Scott and Thomas, 2005, p. 44, fig. 2.18d; Pearce et al., 2014b, p. 444, figs. 16 and 17.

Response to environmental gradients. Temperature range from 1.6 to $19.7^{\circ} \mathrm{C}$, optimum $10^{\circ} \mathrm{C}$, the species has a unimodal symmetric response to SST (Fig. 7c, Table 1). Coscinodiscus radiatus has a statistically significant response to sea ice in our dataset with highest abundances found at $0 \%$ sea ice concentrations (Fig. 7d).

Distribution. Found in the subpolar North Atlantic and Nordic Seas, where it reaches abundances up to ca. $10 \%$ of the total assemblage, and off western Svalbard tracing the North Atlantic current (Fig. 7b). The species is virtually absent from the Baffin Bay and Labrador Sea.

Coscinodiscus radiatus is not often discussed in the literature. According to Berner et al. (2008) it is most strongly associated with the Norwegian Atlantic Current assemblage despite not being among the most common species in the assemblage. Coscinodiscus radiatus can be classified as a warm- to temperate-water species (Fig. 7c), distributed along the warm North Atlantic Current. It is also common in the mixed water region off Norway and in the central North Atlantic (sensu Andersen et al., 2004a). 
A

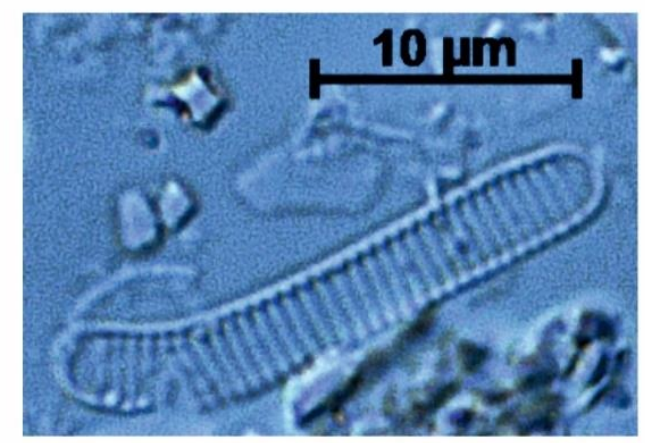

B
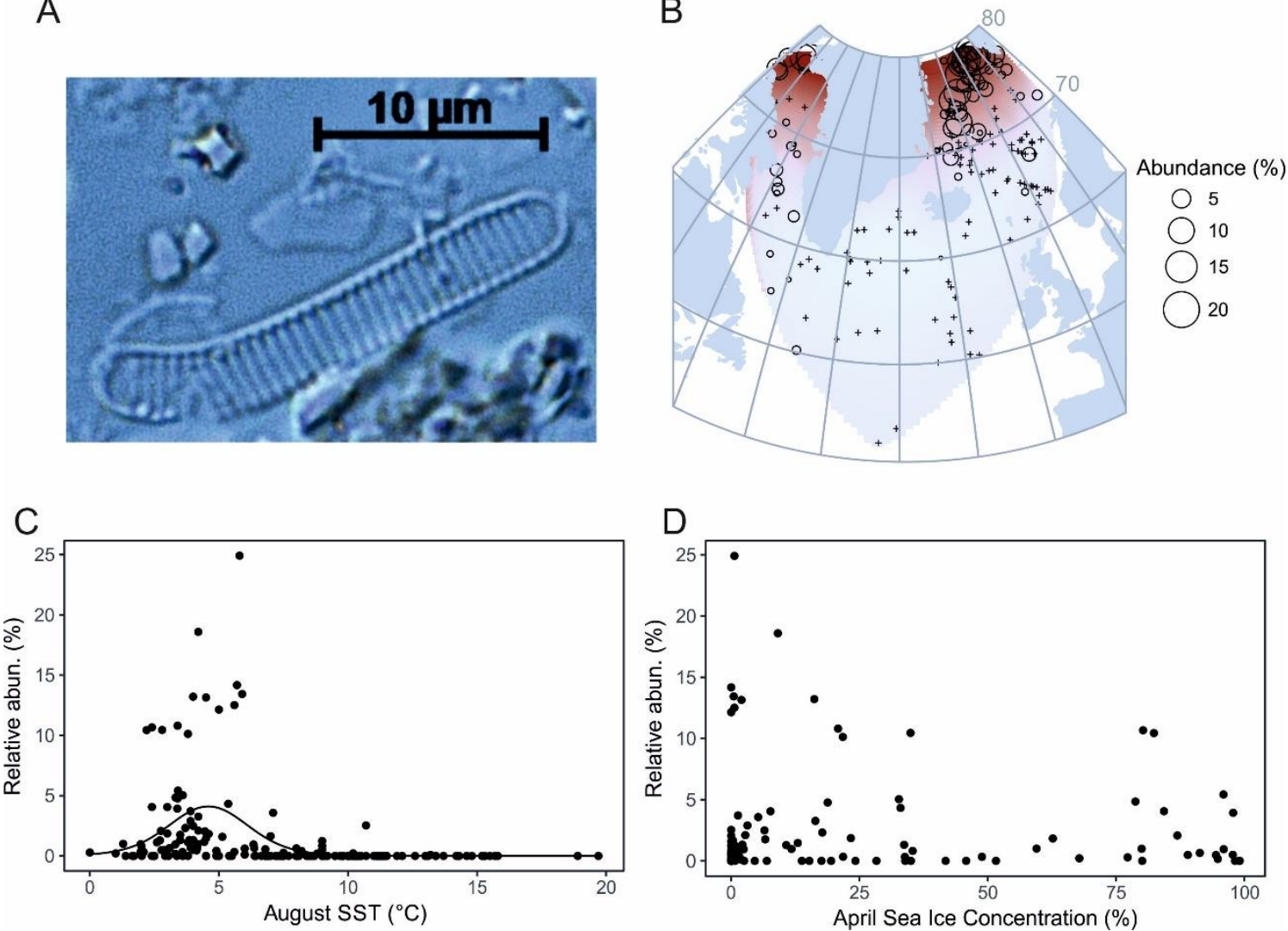

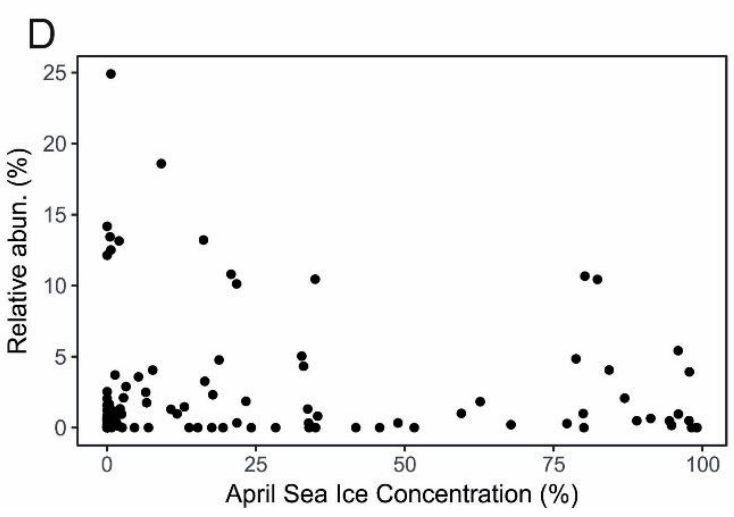

Figure 8. Fragilariopsis cylindrus. a) Light microscopy image of the species (sample from Baffin Bay, core SL-170), b) Geographical distribution (dark red shading indicates where abundances are highest, and symbol + refers to location with 0 abundances), c) Response to August SST, d) Response to April sea ice concentrations.

Fragilariopsis cylindrus (Grunow) Krieger in Helmcke \& Krieger (Fig. 8)

Basionym. Fragilaria cylindrus Grunow in Cleve and Moller.

Synonym. Nitzschia cylindrus (Grunow) Hasle. Fragilaria nana Steem.Niels. Fragilariopsis cylindrus var. planctonica Willi Krieg., in Helmcke \& Krieger, Fragilariopsis cylindrus f. minor M anguin, Fragilariopsis linearis (Castrac.) Hust. var. intermedia M anguin, Fragilariopsis nana (Steem.Niels.) Paasche.

References. Snoeijs and Vilbaste, 1994, p. 50, pl. 138; Hasle and Syvertsen, 1996, p. 302, pl. 68; Cremer, 1998, p. 40, pl. 17, fig. 11; Bérard-Therriault et al., 1999, p. 64, pl. 55 g-h, 56a-b; Witkowski et al., 2000, p. 359, pl. 213, figs 8-14; Jensen, 2003, p.125, pl. 12, figs. 6-8; Scott and Thomas, 2005, p. 172, fig. 100a-e; Pearce et al., 2014b, p. 446, figs. 23 and 24.

Response to environmental gradients. Temperature range from 0 to $13.2^{\circ} \mathrm{C}$, optimum $4.4^{\circ} \mathrm{C}$ (Fig. $8 \mathrm{C}$ ). Statistically significant relationship to SST but not sea ice, although the species is found at relatively high abundances (5-10\%) when sea ice concentrations are high (75-100\%). Highest abundances at $0 \%$ sea ice concentrations (Fig. 8d).

Distribution. In the Northern Hemisphere this species is found at high abundances (up to $20 \%$ of total assemblage) in Fram Strait, off West Svalbard and south of Nares Strait in the North Water Polynya. It is mainly occurring north of $65^{\circ} \mathrm{N}$, but also found in a few samples south of $60^{\circ} \mathrm{N}$ in the Labrador Sea.

Fragilariopsis cylindrus is described as a cold water species, found in the Arctic and the Antarctic. In the Northern Hemisphere, it has been described as very common in the Nordic Seas (Koç Karpuz and Schrader, 1990) and in Baffin Bay (Williams, 1990). It is frequently associated with sea ice and/or spring melting, and widely used as a sea ice indicator together with Fragilariopsis oceanica (e.g., De Sève, 1999; von Quillfeldt, 
2001; Jiang et al., 2001; 2002; Jensen et al., 2004; Witak et al., 2005; Krawczyk et al., 2010; 2013; 2016; Sha et al., 2014, M iettinen et al., 2015). Although Fragilariopsis cylindrus shows high relative abundances at high sea ice concentrations in our dataset (Fig. 8d) and is strongly associated with the spring sea ice limit in Fram Strait (Fig. 8b), it is also common in areas either exhibiting low sea ice concentrations or ice-free conditions year round. The taxon is also a common constituent of the spring bloom in the weakly brackish northern parts of the Baltic Sea (e.g., Tuovinen et al., 2009), and is often defining diatom assemblages at the bottom of Greenlandic fjords, which receive meltwater from the ice sheet and have a lower salinity (Weckström, $\mathrm{K}$. unpublished data). The species is a very good cold-water indicator with a well-defined optimum around $4-5^{\circ} \mathrm{C}$ (Fig. 8c). However, while Fragilariopsis cylindrus is clearly related to sea ice based on previous studies, its use as a sea ice indicator species is not as straightforward as previously assumed (Fig. 8d), and requires careful assessment depending on the study location (Fig. 8b).

A
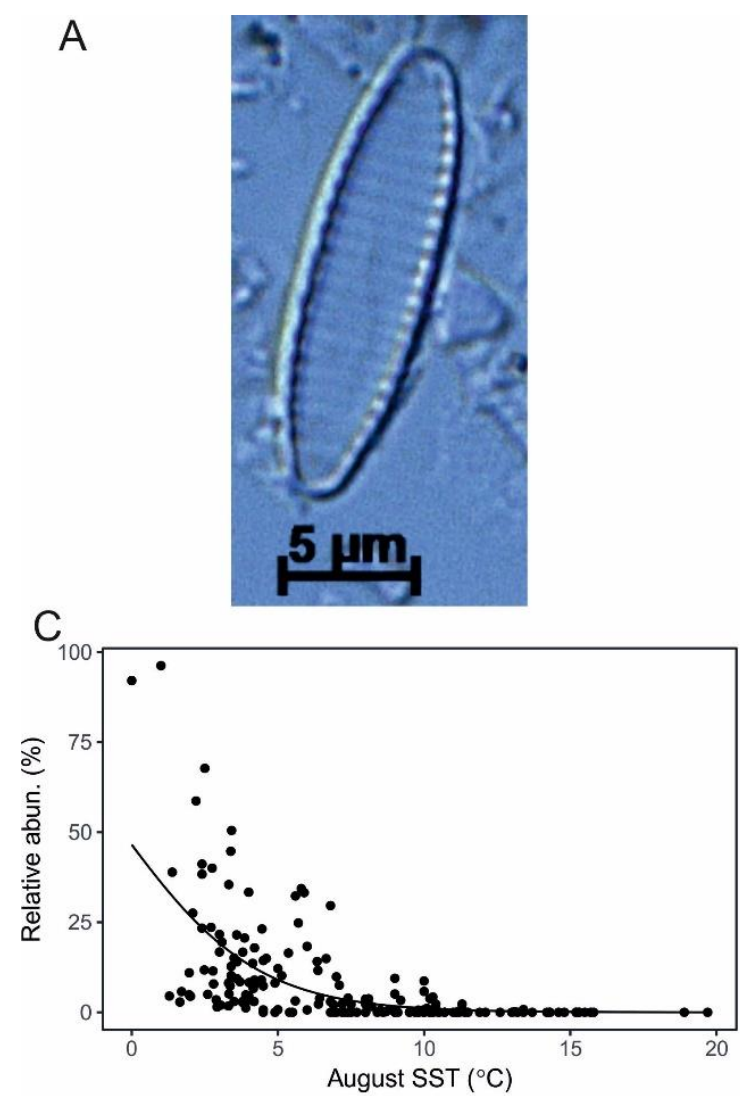

B
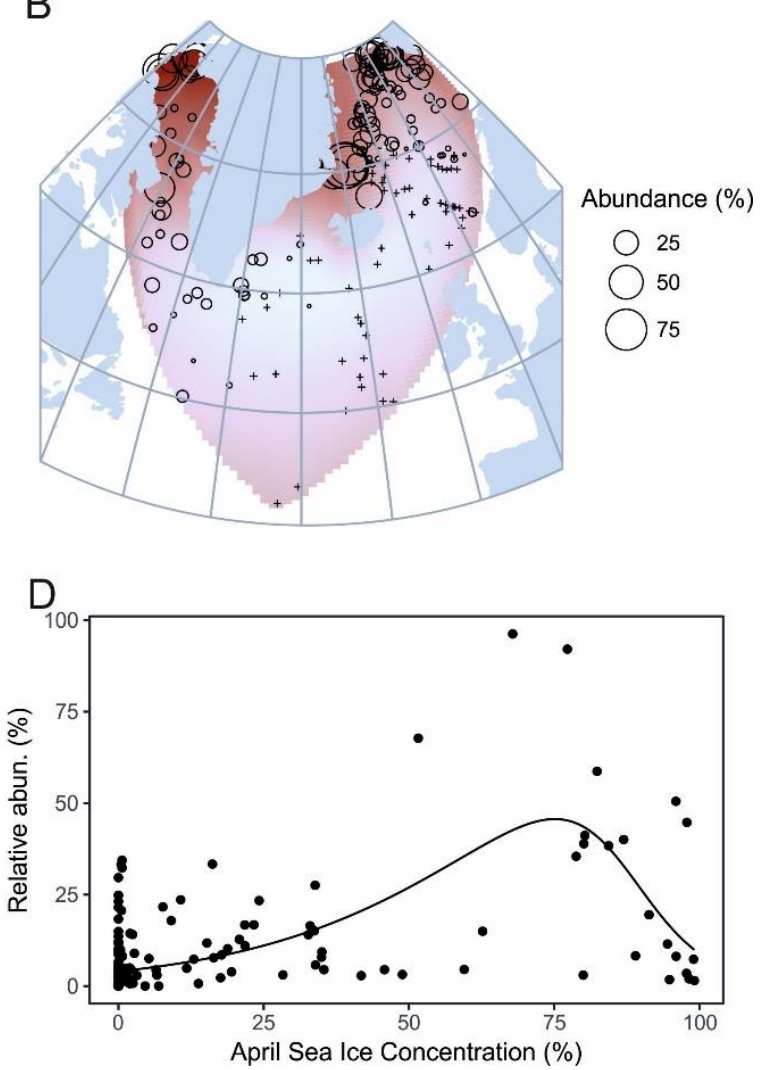

Figure 9. Fragilariopsis oceanica. a) Light microscopy image of the species (sample from Baffin Bay, core SL-170), b) Geographical distribution (dark red shading indicates where abundances are highest, and symbol + refers to location with 0 abundances), c) Response to August SST, d) Response to April sea ice concentrations.

Fragilariopsis oceanica (Cleve) Hasle (Fig. 9)

Basionym. Fragilaria oceanica (Cleve).

Synonym. Fragilaria arctica Grunow in Cleve \& Grunow, Nitzschia grunowii Hasle.

References. Hasle and Syvertsen, 1996, p. 299, pl. 67; Cremer, 1998, p. 40, pl. 17, figs. 9-10; Bérard-Therriault 385 et al., 1999, p. 65, pl. 56c-f, h; Witkowski et al., 2000, p. 361, pl. 213, figs. 17-21; Jensen, 2003, p. 125, pl. 13, figs. 2-6; Pienitz et al., 2003, p. 68, pl. 22, figs. 9-14; Pearce et al., 2014b, p. 446, figs. 25-27. 
Response to environmental gradients. Temperature range from 0 to $13.1^{\circ} \mathrm{C}$, optimum $3.6^{\circ} \mathrm{C}$ (Fig. $9 \mathrm{C}$ ). Statistically significant relationship to both SST and sea ice. Highest abundances are found at ca. $75 \%$ sea ice concentrations (Fig. 9d).

Distribution. Fragilariopsis oceanica is abundant (up to $75 \%$ of total assemblages) and widely distributed in the studied dataset. Highest abundances are found along the spring Arctic sea ice limit in Fram Strait and off East Greenland and south of Nares Strait in the North Water Polynya. It should be noted that in the dataset used, the abundances of Fragilariopsis oceanica also likely include Fragilariopsis reginae-jahniae and Fossula arctica. Both are relatively new species (described in 2000 and 1996, respectively), which is the reason why they have not been included in the dataset (137 sites were analysed before these species were described). While the former generally seems to be relatively rare, the latter can occur at high abundances in the northern North Atlantic. Both species are cold-water, sea-ice related species (von Quillfeldt, 2000), which appear to have similar distributions to Fragilariopsis oceanica.

Fragilariopsis oceanica is found in Arctic and subarctic cold water regions. It is widely associated with sea ice and grouped into a sea ice assemblage in several studies (e.g., Hasle and Syvertsen, 1996; Jiang et al., 2001; von Quillfeldt, 2001; Witak et al., 2005; Justwan and Koç, 2008; Krawczyk et al., 2010; 2013; Caissie, 2012). Both Fragilariopsis oceanica and Fragilariopsis cylindrus regularly occur in the marginal ice zone (MIZ) and are part of the spring bloom associated with melting ice (Jiang et al., 2001; von Quillfeldt, 2000; 2003). Their distribution in the northern North Atlantic is very similar, although Fragilariopsis oceanica is clearly more abundant (Fig. 9b). However, while Fragilariopsis cylindrus can be found in truly brackish environments (e.g., the Baltic Sea), this is not the case for Fragilariopsis oceanica, which is completely absent from the Baltic Sea and often rarer than Fragilariopsis cylindrus at the bottom of Greenlandic fjords (Weckström, K., unpublished data). The species has an even lower optimum to SST than Fragilariopsis cylindrus, displaying highest abundances below $3^{\circ} \mathrm{C}$. While the potential inclusion of Fragilariopsis reginae-jahniae in the total abundances of Fragilariopsis oceanica is not likely affecting the obtained results (due to its apparent rarity), the inclusion of Fossula arctica could have an effect on these. Although Fossula arctica and Fragilariopsis oceanica appear 412 

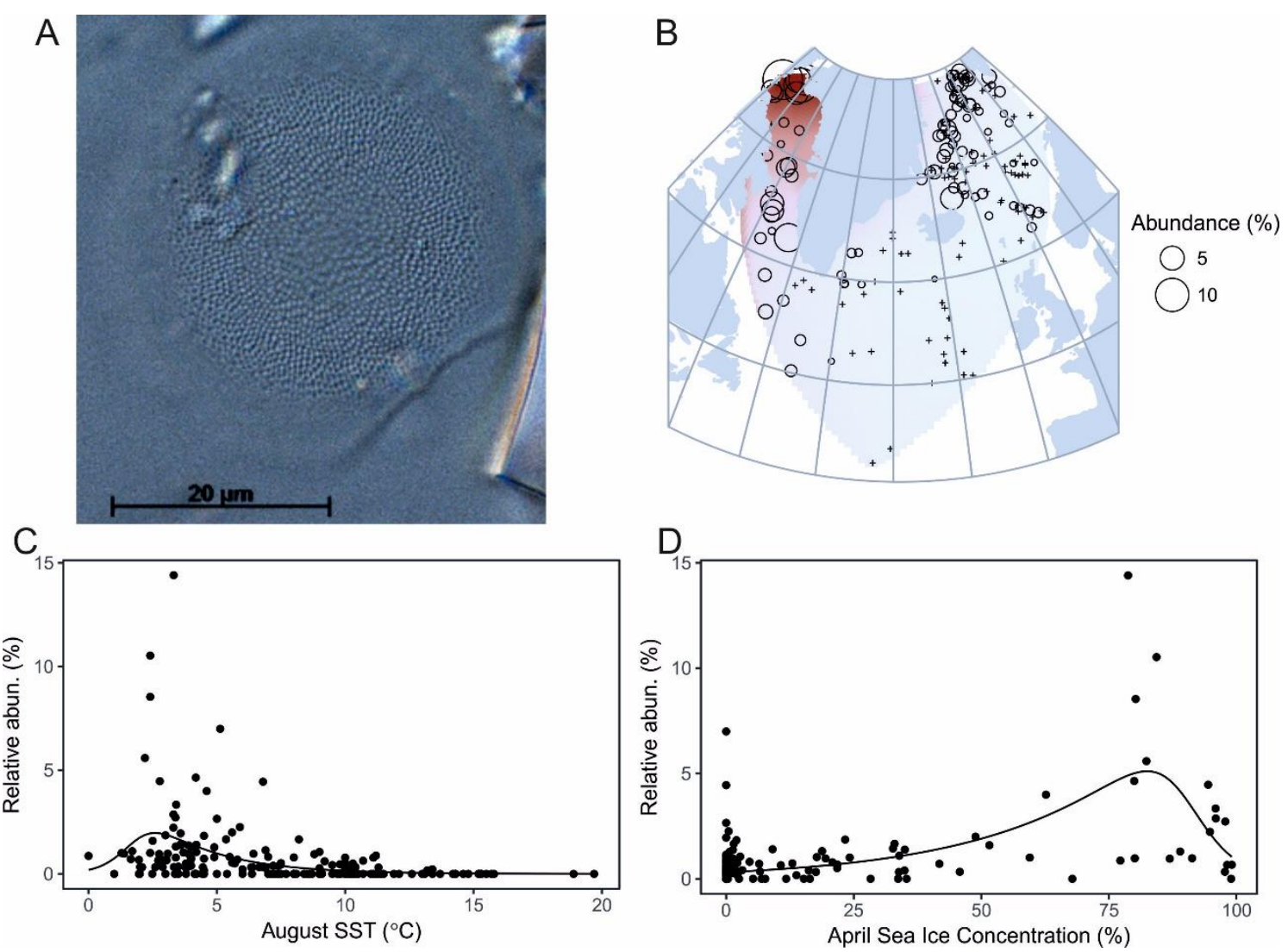

Figure 10. Porosira glacialis. a) Light microscopy image of the species (sample from Baffin Bay, core SL-170), b) Geographical distribution (dark red shading indicates where abundances are highest, and symbol + refers to location with 0 abundances), c) Response to August SST, d) Response to April sea ice concentrations.

Porosira glacialis (Grunow) Jørgensen (Fig. 10)

Basionym. Podosira hormoides var. glacialis Grunow.

Synonyms. Podosira glacialis (Grunow) Cleve, Lauderia glacialis (Grunow) Gran, Porosira antarctica O.G. Kozlova.

References. Sancetta, 1982, p. 235, pl. 3, figs. 16-18; Hasle and Syvertsen, 1996, p. 41, pl 3; Cremer, 1998, p. 71, pl. 34, fig. 7; Snoeijs and Balashova, 1998, p. 87, pl. 475; Bérard-Therriault et al., 1999, p. 21, pl. 3d, f-h; Jensen, 2003, p. 119, pl. 6, figs. 8-10; Scott and Thomas, 2005, p. 84, fig. 2.41a-f; Pearce et al., 2014b, p. 448, figs. 36-37.

Response to environmental gradients. Temperature range from 0 to $13.4^{\circ} \mathrm{C}$, optimum $4.3^{\circ} \mathrm{C}$ (Fig. $10 \mathrm{C}$ ). Statistically significant relationship to both SST and sea ice. Highest abundances at $75-100 \%$ sea ice concentrations (Fig. 10d).

Distribution. In the studied dataset, highest abundances of Porosira glacialis are found south of Nares Strait in the North Water Polynya, Davis Strait, Baffin Bay and north of Iceland (Fig. 10b). It is also relatively abundant east of Greenland along the spring Arctic sea ice limit. Compared to e.g., Fragilariopsis oceanica, Porosira glacialis is much rarer, not exceeding $10 \%$ of the total assemblages at our sites.

Porosira glacialis has been described as an Arctic species, but it is found from cold to temperate waters, and also in the Southern Ocean (Hasle and Syvertsen, 1996; Pike et al., 2009; Krawzcyk et al., 2013). Porosira glacialis is often associated with sea ice and grouped into a sea ice assemblage in several studies in (Koç Karpuz and Schrader, 1990; Justwan and Koç, 2008; Krawczyk et al., 2016). The species thrives in the M arginal Ice Zone occurring during and after the spring bloom, yet not as a dominating species (von Quillfeldt, 2000), which is also evident in our dataset where highest abundances are $<10 \%$ of the total assemblages. Porosira 
glacialis can be used as an indicator species for low SST and high sea ice concentrations (highest abundances around $75 \%$ sea ice concentrations).

A

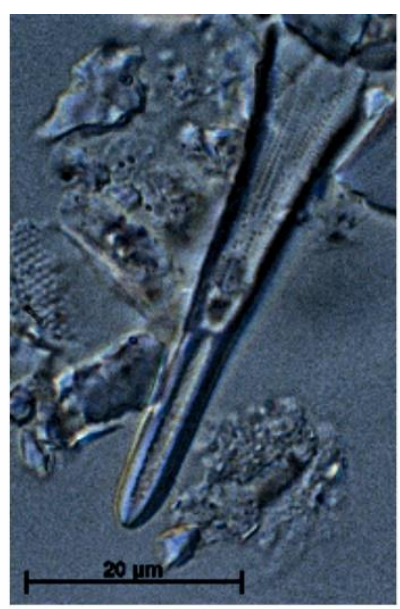

C

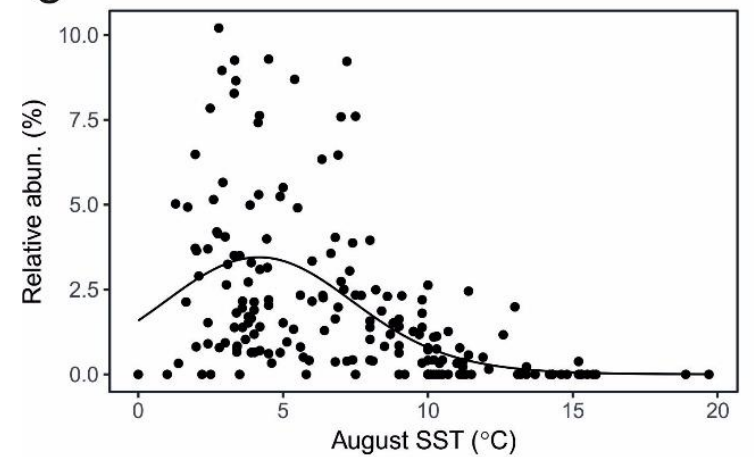

B

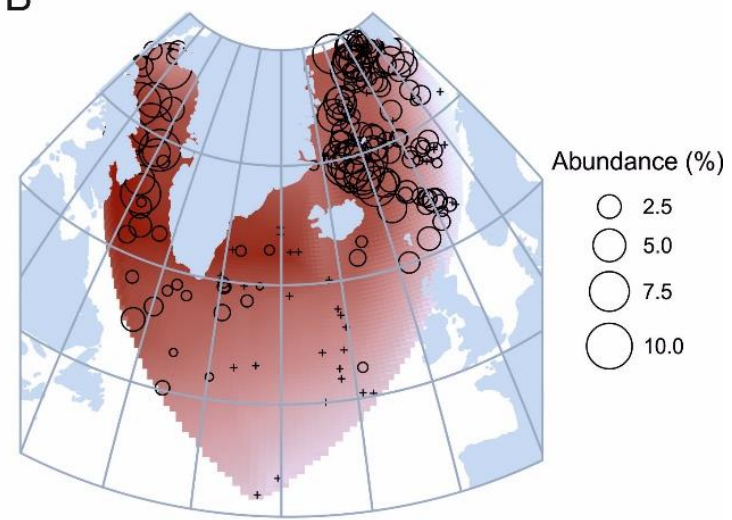

Figure 11. Rhizosolenia hebetata f. hebetata. a) Light microscopy image of the forma (sample from Baffin Bay, core SL170), b) Geographical distribution (dark red shading indicates where abundances are highest, and symbol + refers to location with 0 abundances), c) Response to August SST, d) Response to April sea ice concentrations.

Rhizosolenia hebetata Bailey f. hebetata (Fig. 11)

Synonym. Rhizosolenia hebetata f. hiemalis Gran.

References. Sancetta, 1982, p. 237, pl. 4, figs. 5-6; Hasle and Syvertsen, 1996, p. 149, pl. 27; Bérard-Therriault et al., 1999, p. 36, pl. 21a-c.

Response to environmental gradients. Temperature range from 1.3 to $15.2^{\circ} \mathrm{C}$, optimum $5.1^{\circ} \mathrm{C}$ (Fig. $11 \mathrm{C}$ ). Statistically significant relationship to SST, but not to sea ice. Reaches highest abundances (ca. 10\%) both in ice-free conditions and in near full sea ice cover (Fig. 11d).

Distribution. Rhizosolenia hebetata $\mathrm{f}$. hebetata is very common in the studied dataset and present in most of the samples, excluding the south-east sector of the North Atlantic region. Generally, Rhizosolenia hebetata f. hebetata occurs at relatively low abundances $(<10 \%)$, the highest abundances are found at high latitudes (above ca. $65^{\circ} \mathrm{N}$ ) in Baffin Bay, south of Nares Strait, the Nordic Seas and Fram Strait. Rhizosolenia hebetata $f$. hebetata is described as a northern cold water region species and defined as an important contributor to the Arctic water assemblage (Fig. 2, Andersen et al., 2004b) and to the Northern Cold Water assemblage (Krawczyk et al., 2010; 2013). It is a clear cold water indicator with an SST optimum around $5^{\circ} \mathrm{C}$ (Fig. 11C). Although it has a relatively similar distribution to many sea-ice-related species, Rhizosolenia hebetata $\mathrm{f}$. hebetata shows no relationship to sea ice, suggesting this forma appears later in the 
season in regions where sea ice is present, occurring after the cold and fresher spring meltwater layer has broken up.

A
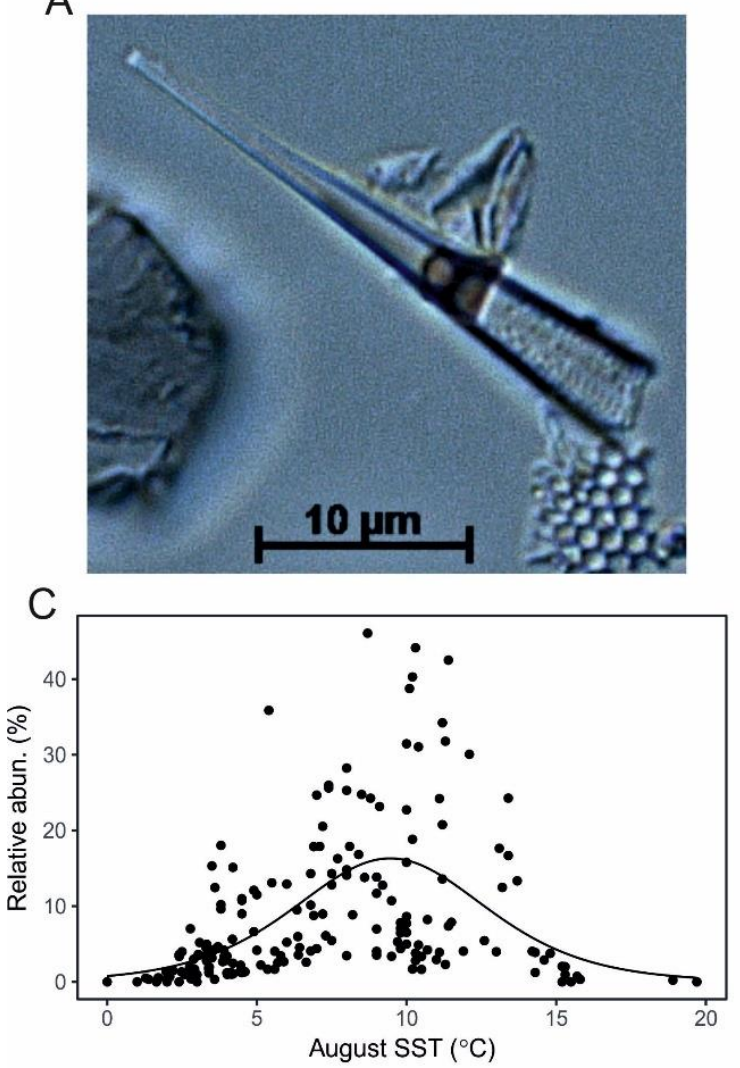

B
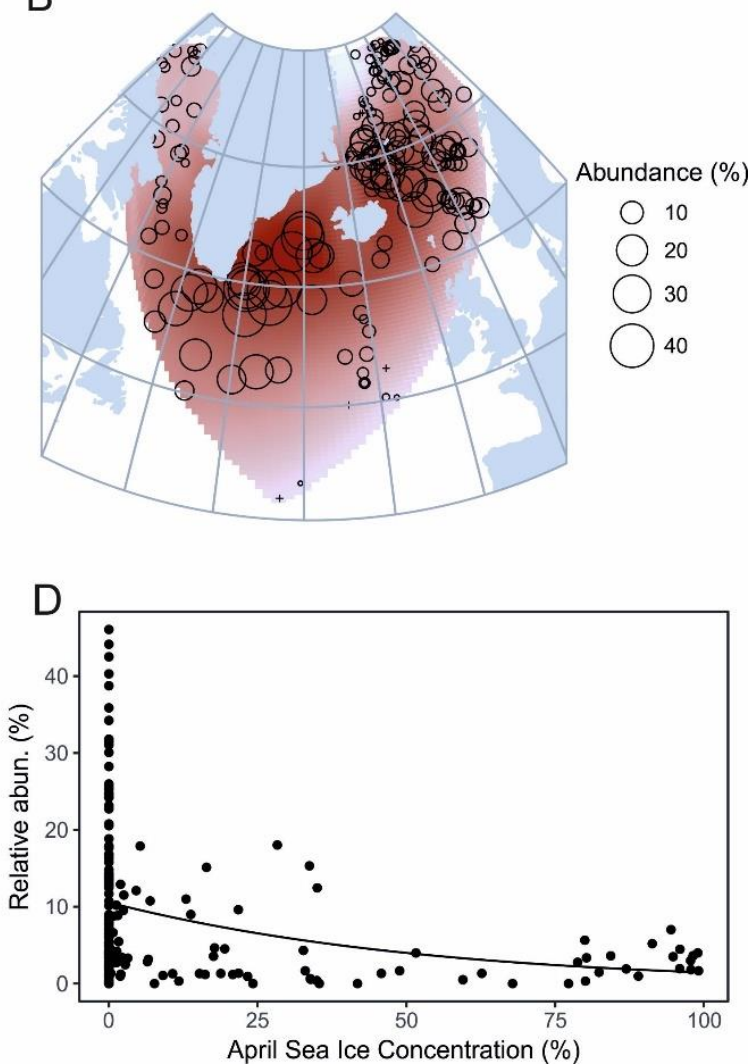

Figure 12. Rhizosolenia hebetata f. semispina. a) Light microscopy image of the forma (sample from Baffin Bay, core SL170), b) Geographical distribution (dark red shading indicates where abundances are highest, and symbol + refers to location with 0 abundances), c) Response to August SST, d) Response to April sea ice concentrations.

Rhizosolenia hebetata f. semispina (Hensen) Gran (Fig. 12)

Basionym. Rhizosolenia semispina Hensen.

Synonym. Rhizosolenia styliformis var. semispina (Hensen) G.Karst

References. Snoeijs and Kasperovičiene, 1996, p. 101, pl. 389; Hasle and Syvertsen, 1996, p. 149, pl. 27; Bérard-Therriault et al., 1999, p. 36, pl. 21d, e, i, k; Jensen, 2003, p. 120, pl. 6, figs 5- 7; Scott and Thomas, 2005, p. 81, fig. 2.37c; Pearce et al., 2014b, p. 448, figs. 39-40.

Response to environmental gradients. Temperature range from $1.3^{\circ} \mathrm{C}$ to $18.9^{\circ} \mathrm{C}$, optimum temperature $8.5^{\circ} \mathrm{C}$ (Fig. 12C). Statistically significant relationship to both SST and sea ice. Highest abundances ( $>40 \%)$ are found in ice-free regions (Fig. 12d).

Distribution. Rhizosolenia hebetata f. semispina is very abundant in the northern North Atlantic and was found in almost every sample in the dataset. Highest abundances (up to 40\%) are found in SE Greenland/NE Labrador Sea, around Iceland and from the Nordic Seas.

Previously Rhizosolenia hebetata f. semispina has been show to occur in northern cold water regions (Hasle and Syvertsen, 1996). It is further described as an important contributor to the Arctic Water and Subarctic Water assemblages (Fig. 2; Andersen et al., 2004b) and to the Arctic-Norwegian Waters M ixing assemblage (Koç Karpuz and Schrader, 1990). The distribution of Rhizosolenia hebetata f. semispina in the studied dataset corresponds to the distributions of these assemblages. Compared to the distribution of Rhizosolenia 
hebetata $\mathrm{f}$. hebetata in our dataset, highest abundances of Rhizosolenia hebetata $\mathrm{f}$. semispina are found in warmer waters, around ca. $10^{\circ} \mathrm{C}$ (Fig. $12 \mathrm{C}$ ) and it is abundant also below ca. $65^{\circ} \mathrm{N}$, whereas Rhizosolenia hebetata f. hebetata is most abundant above this latitude (Fig. 12b). The distribution of Rhizosolenia hebetata f. semispina roughly follows the Polar Front.
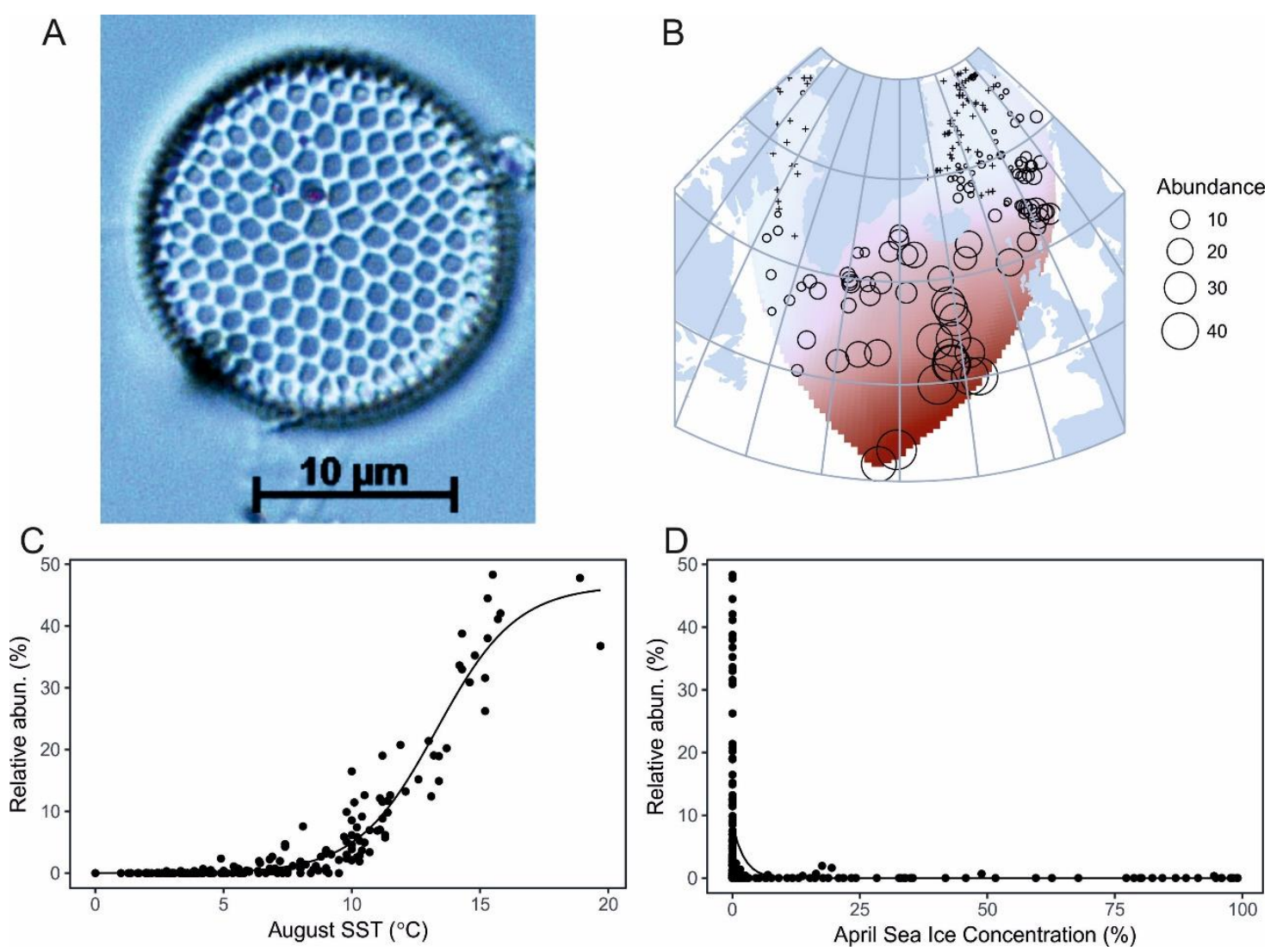

Figure 13. Shionodiscus oestrupii. a) Light microscopy image of the species (sample from Baffin Bay, core SL-170), b) Geographical distribution (dark red shading indicates where abundances are highest, and symbol + refers to location with 0 abundances), c) Response to August SST, d) Response to April sea ice concentrations.

Shionodiscus oestrupii (Ostenfeld) Alverson, Kang et Theriot (Fig. 13)

Basionym. Coscinosira oestrupii Ostenfeld.

Synonym. Thalassiosira oestrupii (Ostenfeld) Hasle: Thalassiosira antiqua var. septata Proshkina-Lavrenko. References. Snoeijs and Kasperovičiene, 1996, p. 109; Hasle and Syvertsen, 1996, p. 83, pl. 12; Jensen, 2003, p. 123, pl. 11, figs. 1-2; Scott and Thomas, 2005, p. 108, fig. 2.56; Pearce et al., 2014b, p. 453, figs. 66-67. Response to environmental gradients. Temperature range from 2.8 to $19.7^{\circ} \mathrm{C}$, optimum $13.4^{\circ} \mathrm{C}$. Statistically significant relationship to SST and sea ice, virtually absent in areas with seasonal sea ice cover (Fig. 13C, d). Distribution. Very abundant in the North Atlantic. Highest abundances in our dataset (up to 40\%) are found at latitudes between $40-60^{\circ} \mathrm{N}$ and along the warm and saline North Atlantic and Irminger Currents (Fig. 13b). Shionodiscus oestrupii is described as a cosmopolitan species that prefers warm to temperate (Atlantic) waters and higher salinities (Hasle and Syvertsen, 1996; Koç Karpuz and Schrader, 1990; Jiang et al., 2001; Andersen et al., 2004b). The distribution of Shionodiscus oestrupii reflects the North Atlantic Current assemblage in Andersen et al. (2004b) (Fig. 2), as it is the main species in the assemblage. In Baffin Bay, Shionodiscus oestrupii has been described as part of the Warm/temperate water assemblage propagating north along the West Greenland margin (Krawczyk et al., 2010; 2013). In our data set, Shionodiscus oestrupii 
does not appear north of Davis Strait, however, our dataset does not include sites close to the SW and W Greenland margins (Fig. 13b). Shionodiscus oestrupii can be defined as a very robust warm (Atlantic) water indicator.
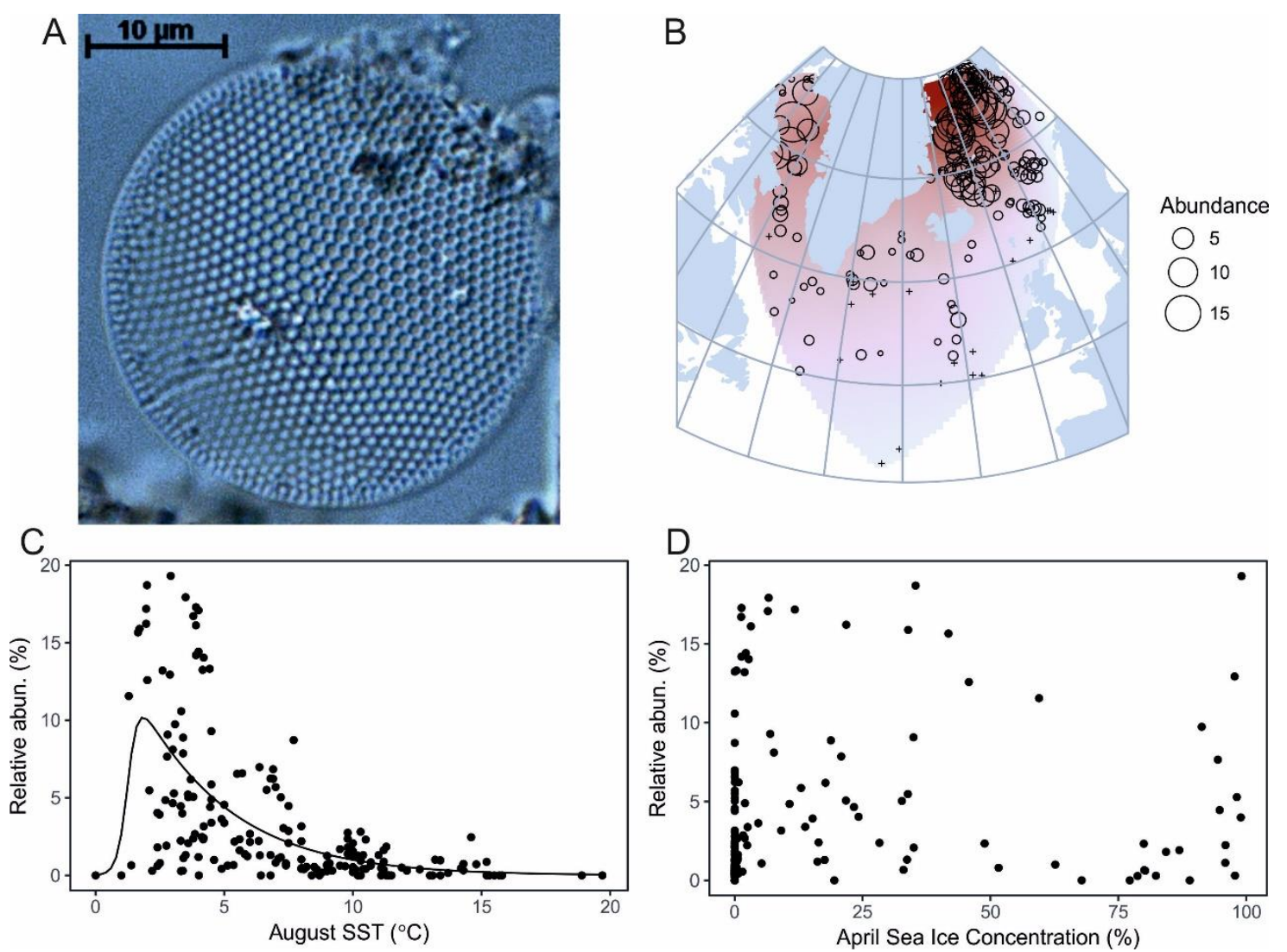

Figure 14. Shionodiscus trifultus. a) Light microscopy image of the species (sample from Baffin Bay, core SL-170), b) Geographical distribution (dark red shading indicates where abundances are highest, and symbol + refers to location with 0 abundances), c) Response to August SST, d) Response to April sea ice concentrations.

Shionodiscus trifultus (G. Fryxell) Alverson, Kang et Theriot (Fig. 14)

Basionym. Thalassiosira trifulta G. Fryxell in Fryxell \& Hasle.

References. Sancetta, 1982 p. 244, pl. 5, figs. 10-12, pl. 6, figs. 1-2; Hasle and Syvertsen, 1996, p. 87, pl. 12; Scott and Thomas, 2005, p. 114, fig. 2.63a-f.

Response to environmental gradients. Temperature range from 1.3 to $15.2^{\circ} \mathrm{C}$, optimum $4.4^{\circ} \mathrm{C}$. Statistically significant relationship to SST but not to sea ice occurring at equally high abundances in both high and low sea ice concentrations (Fig. 14c, d).

Distribution. Most abundant in our data set (up to 15\%) at high latitudes in Fram Strait, Nordic Seas and northern Baffin Bay.

Shionodiscus trifultus is described as an indicator for cold water (Caissie, 2012) and it is an important contributor to the Greenland Arctic Waters assemblage in Andersen et al. (2004b) (Fig. 2) alongside Thalassiosira anguste-lineata. In Baffin Bay, Shionodiscus trifultus has also been described as a minor contributor to the summer pack ice assemblage (Williams, 1986). Based on existing literature and our results, Shionodiscus trifultus is a robust cold-water indicator species (Fig. 14b, c, d). 
A

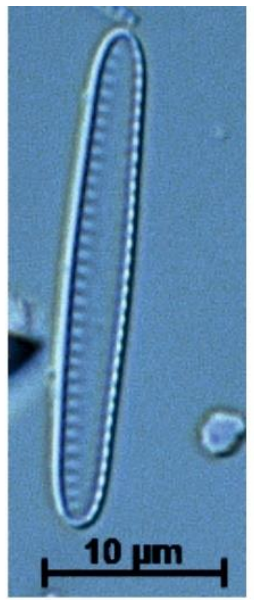

C

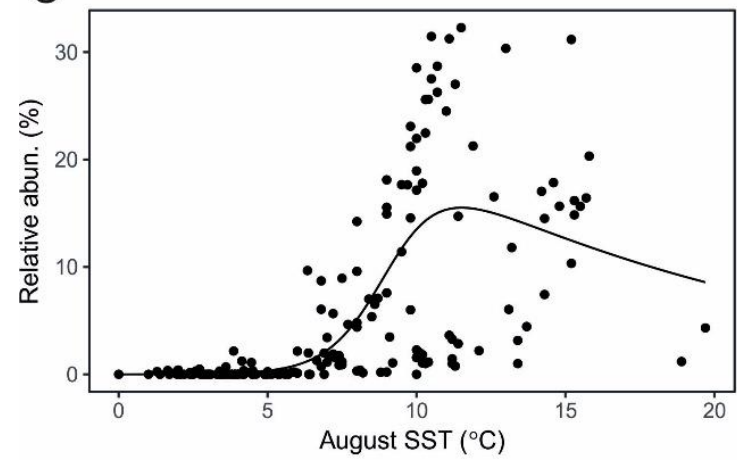

B

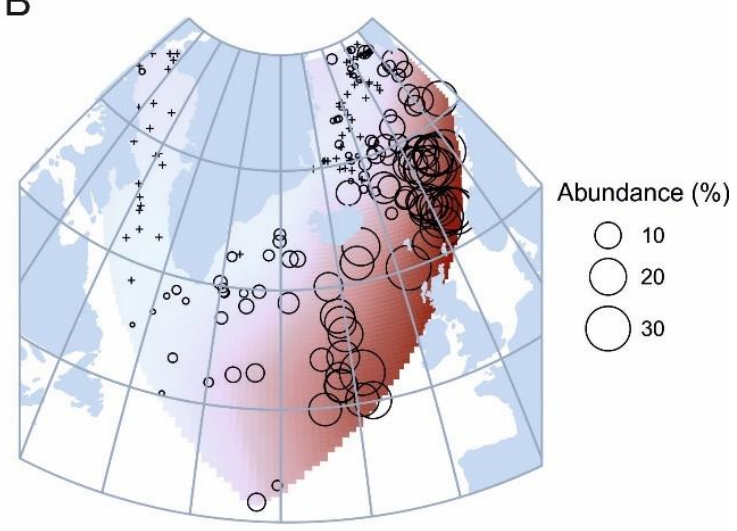

Figure 15. Thalassionema nitzschioides. a) Light microscopy image of the species (sample from Baffin Bay, core SL-170), b) Geographical distribution (dark red shading indicates where abundances are highest, and symbol + refers to location with 0 abundances), c) Response to August SST, d) Response to April sea ice concentrations.

Thalassionema nitzschioides (Grunow) ex Mereschkowsky (Fig. 15)

Basionym. Synedra nitzschioides Grunow.

Synonyms. Synedra nitzschioides Grunow, Thalassiothrix nitzschioides (Grunow) Grunow in Van Heurck, Synedra nitzschioides var. minor Cleve, Thalassiothrix curvata Castracane, Thalassiothrix frauenfeldii var. nitzschioides (Grunow) Jörgensen.

References. Sancetta, 1982, p. 239, pl. 4, figs. 11-13; Snoeijs and Vilbaste, 1994, p. 106, pl. 194; M etzeltin and Witkowski, 1996, p. 118, 128; Hasle and Syvertsen, 1996, p. 257, pl. 55-57; Bérard-Therriault et al., 1999, p. 58, pl. 48d, e, g; Pienitz et al., 2003, p. 31, pl. 8, figs. 5-10; Scott and Thomas, 2005, p. 144, fig. 2.80; Pearce et al., 2014b, p. 452, figs. 46-49.

Response to environmental gradients. Temperature range from 1.3 to $19.7^{\circ} \mathrm{C}$, optimum $11.1^{\circ} \mathrm{C}$. Statistically significant relationship to SST and sea ice (Fig. 15c, d).

Distribution. Although Thalassionema nitzschioides is an abundant species in the northern North Atlantic, its distribution closely follows the warm waters of the North Atlantic Current. Highest abundances (up to 30\%) are found along the North Atlantic Current from around $50^{\circ} \mathrm{N}$ up to the southern tip of the Svalbard archipelago in ice-free areas (15b).

Thalassionema nitzschioides is described as a warm/temperate cosmopolitan species, excluding the high Arctic and Antarctic regions (Sancetta, 1982; Hasle and Syvertsen, 1996; Jiang et al., 2001; Krawczyk et al., 2010; 2014). In the northern North Atlantic, it is tightly associated with Atlantic Water and described as the main contributor to the Norwegian-Atlantic Current assemblage and also contributes to the North Atlantic Current assemblage (Fig. 2; Koç Karpuz and Schrader, 1990; Andersen et al., 2004b). Jiang et al. (2001) found 
high abundances of Thalassionema nitzschioides in the Mixing Diatom assemblage (assemblage influenced by both the warm Irminger Current and the cold East Greenland and East Iceland Currents) and in the warm water diatom assemblage. In the studied dataset, Thalassionema nitzschioides was present only in one sample from the Baffin Bay region. It has, however, been found along the continental shelves and has in earlier literature been defined as a coastal planktonic species (Williams, 1986 and references therein). Thalassionema nitzschioides is rare in areas influenced only by cold currents showing highest abundances at SSTs between ca. 10 and $15^{\circ} \mathrm{C}$ (Fig. 15C). This species can be considered a reliable warm (Atlantic) water indicator.

A

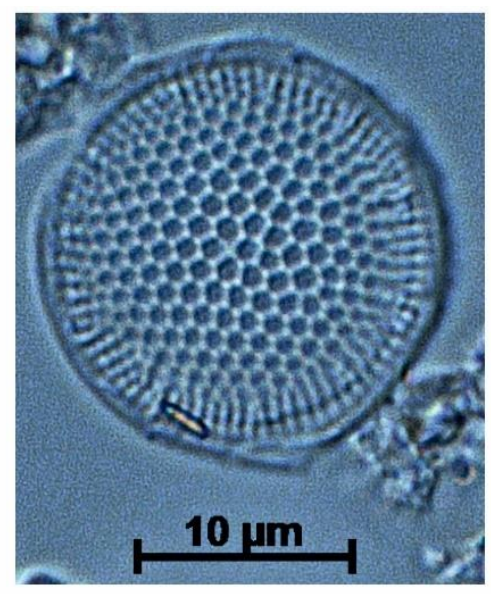

C

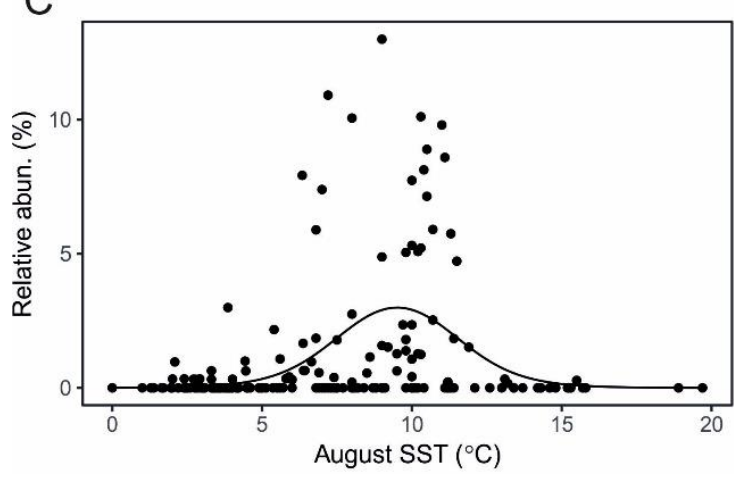

B

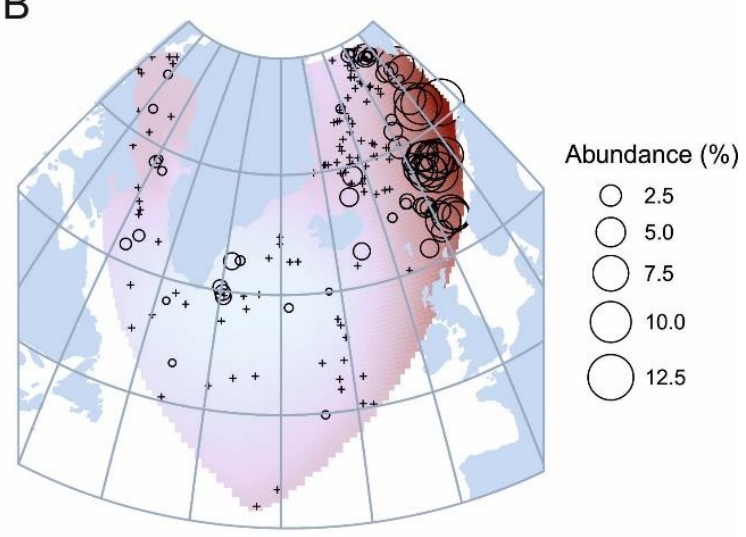

D

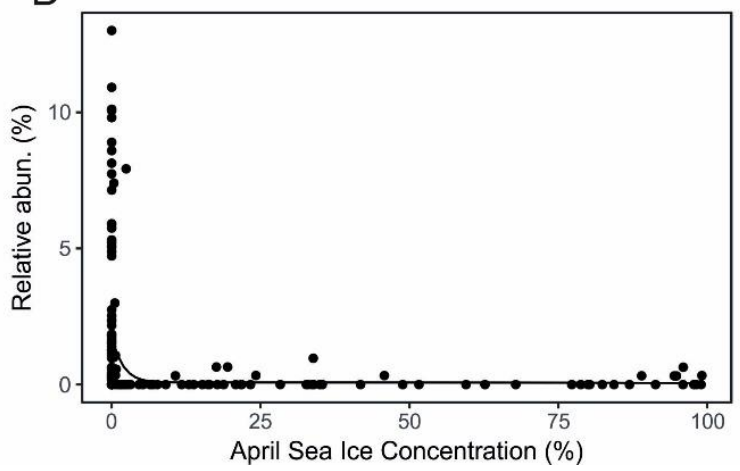

581

Figure 16. Thalassiosira angulata. a) Light microscopy image of the species (sample from Southeast Greenland, core MD99-2322), b) Geographical distribution (dark red shading indicates where abundances are highest, and symbol + refers to location with 0 abundances), c) Response to August SST, d) Response to April sea ice concentrations.

Thalassiosira angulata (Gregory) Hasle (Fig. 16)

Basionym. Orthosira angulata Gregory.

Synonyms. Thalassiosira decipiens (Grunow) Jørgensen non Thalassiosira decipiens (Grunow) Jørgensen in Hasle 1979.

References. Hasle and Syvertsen, 1996, p. 51, pl. 4; Cremer, 1998, p. 76, pl. 37, figs. 2-3; Jensen, 2003, p. 120, pl. 7, fig. 1; Pearce et al., 2014b, p. 452, figs. 50-51.

Response to environmental gradients. Temperature range from 2.0 to $15.5^{\circ} \mathrm{C}$, optimum $9.1^{\circ} \mathrm{C}$. Statistically significant relationship to SST and sea ice. (Fig. 16c, d).

Distribution. Highest abundances (up to $12.5 \%$ ) are observed in the Nordic Seas under the North Atlantic Current. Present also at low abundances in Baffin Bay, Labrador Sea and SE-Greenland. Very rare south of $60^{\circ} \mathrm{N}$. 
Thalassiosira angulata has been described as a subarctic and temperate species (Hasle and Syvertsen, 1996) with the main distribution area in the North Atlantic (von Quillfeldt, 2000). It is an important contributor to the Norwegian-Atlantic Current assemblage between Norway and Iceland (Fig. 2; Andersen et al., 2004b), also contributing to the Warm/Temperate Water assemblage in Baffin Bay described by Krawczyk et al., (2010; 2013). In our dataset Thalassiosira angulata has a very similar distribution to Thalassionema nitzschioides, but prefers slightly colder waters, between ca. 5 and $10^{\circ} \mathrm{C}$ and, unlike Thalassionema nitzschioides, is rare below $60^{\circ} \mathrm{N}$ (Fig. 16b). This, together with a well-defined temperature optimum would suggest it is a robust indicator species for temperate-water and ice-free conditions.

604

605

606
A
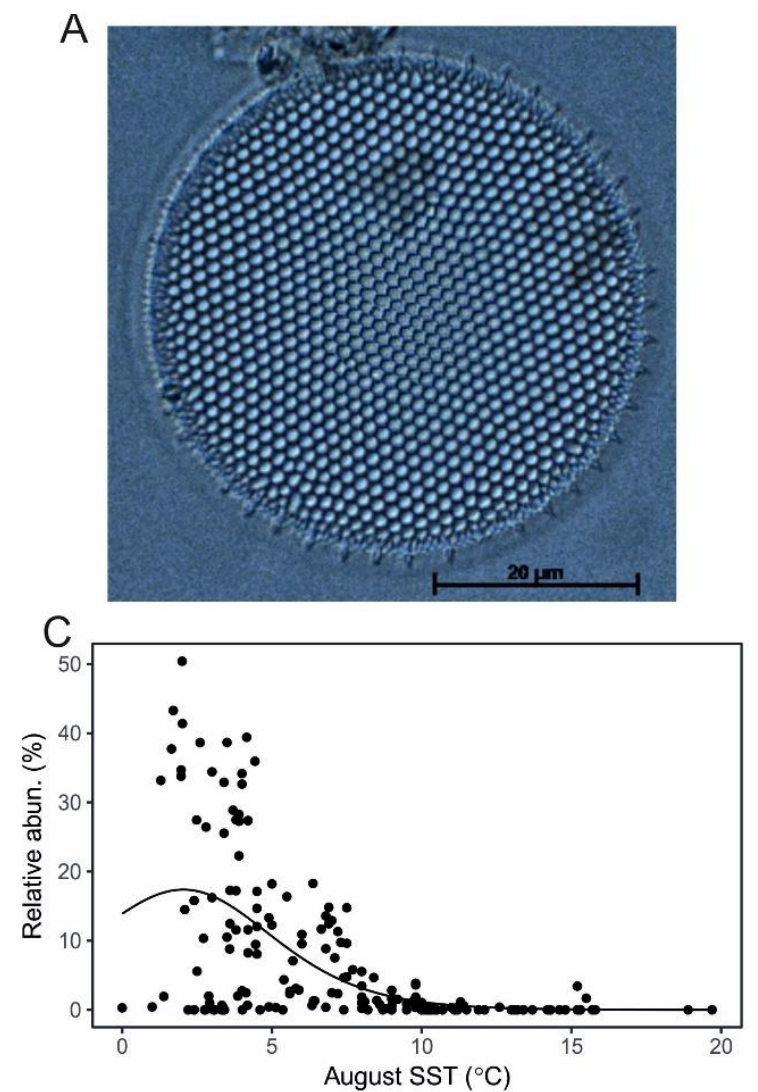

B
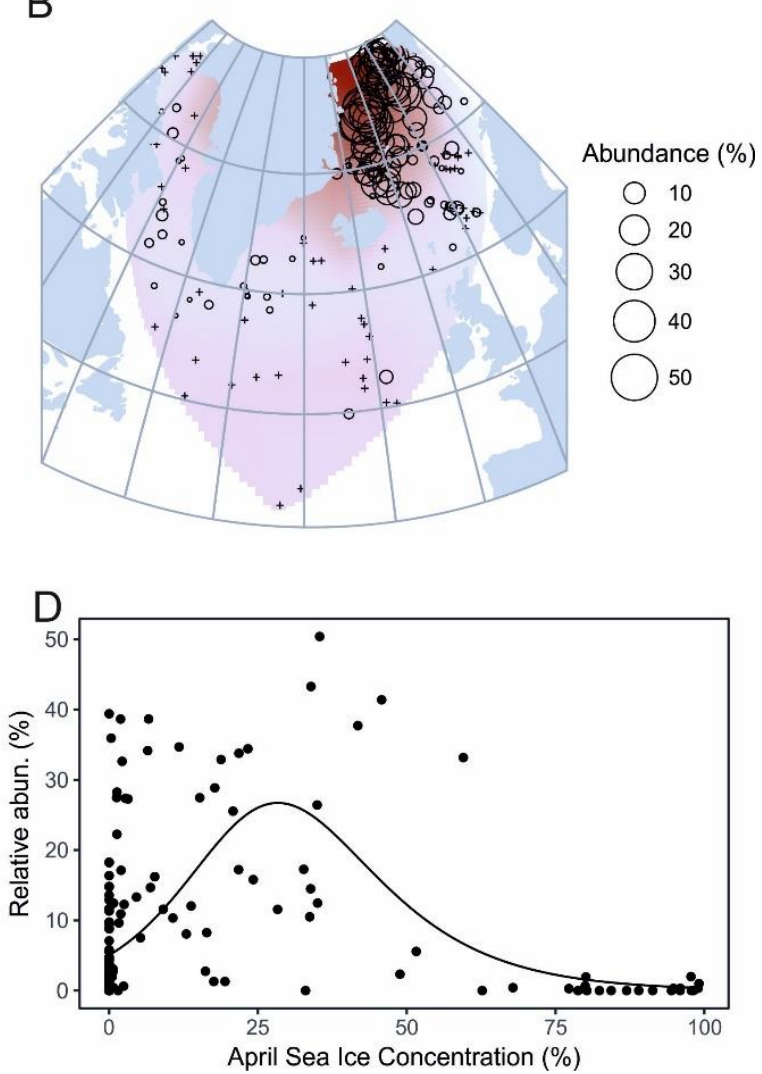

Figure 17. Thalassiosira anguste-lineata. a) Light microscopy image of the species (sample from Southeast Greenland, core M D99-2322), b) Geographical distribution (dark red shading indicates where abundances are highest, and symbol + refers to location with 0 abundances), c) Response to August SST, d) Response to April sea ice concentrations. Note: The subcentral arcs of strutted processes are not clearly visible in more heavily silicified specimens such as illustrated here.

Thalassiosira anguste-lineata (A. Schmidt) G. Fryxell \& Hasle (Fig. 17)

Basionym. Coscinodiscus anguste-lineatus A. Schmidt.

Synonyms. Coscinodiscus polychordus Gran, Thalassiosira polychorda (Gran) Jørgensen, Coscinosira polychorda (Gran) Gran., Coscinodiscus anguste-lineatus A. Schmidt, Thalassiosira ornata ProschkinaLavrenko.

References. Hasle and Syvertsen, 1996, p. 71, pl. 9; Cremer, 1998, p. 77, pl. 37, fig. 6; Snoeijs and Balashova, 1998, p. 106, pl. 494; Bérard-Therriault et al., 1999, p. 22, pl. 4b-d; Jensen, 2003, p. 120, pl. 7, figs. 2-4; Pearce et al., 2014b, p. 452, figs. 53-54. 
Response to environmental gradients. Temperature range from 0 to $15.5^{\circ} \mathrm{C}$, optimum $4.0^{\circ} \mathrm{C}$ (Fig. $17 \mathrm{C}$ ). Statistically significant relationship with SST and sea ice. Highest abundances appear between 25 and $50 \%$ sea ice concentrations (Fig. 17d).

Distribution. The highest abundances (up to 50\%) of Thalassiosira anguste-lineata are tightly centered in the northeastern North Atlantic (the Nordic Seas and Fram Strait). It also appears at clearly lower abundances $(<10 \%)$ in Baffin Bay and Davis Strait and is very rare south of $60^{\circ} \mathrm{N}$ (Fig. 17b).

Thalassiosira anguste-lineata is described as a cosmopolitan species by Hasle and Syvertsen, (1996). It is found in the late Arctic spring bloom, although not as a dominant species (von Quillfeldt, 2000). Thalassiosira anguste-lineata is one of the two main contributors to the Greenland Arctic Waters assemblage (Fig. 2), most commonly occurring in the Greenland Sea (Andersen et al., 2004b). It also contributes to the Northern Cold Water diatoms assemblage in Baffin Bay (Krawczyk et al., 2013). In our dataset, Thalassiosira anguste-lineata is clearly associated with low temperatures (highest abundances at SSTs $<^{\circ} \mathrm{C}$ ), and with Arctic water inflow to the North Atlantic (Fig. 17b, c).

A

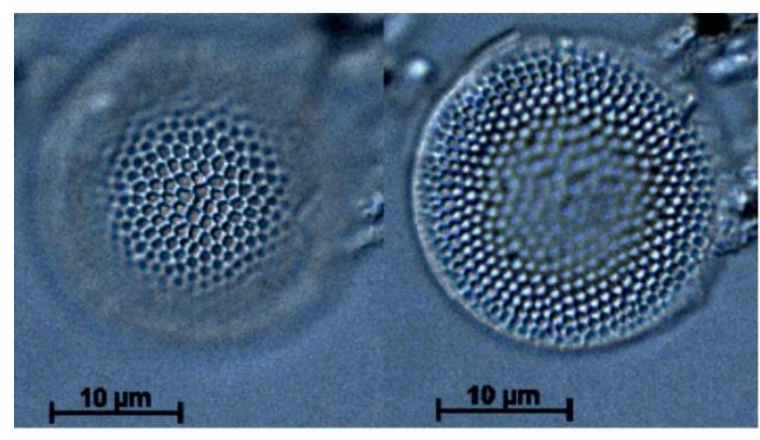

B

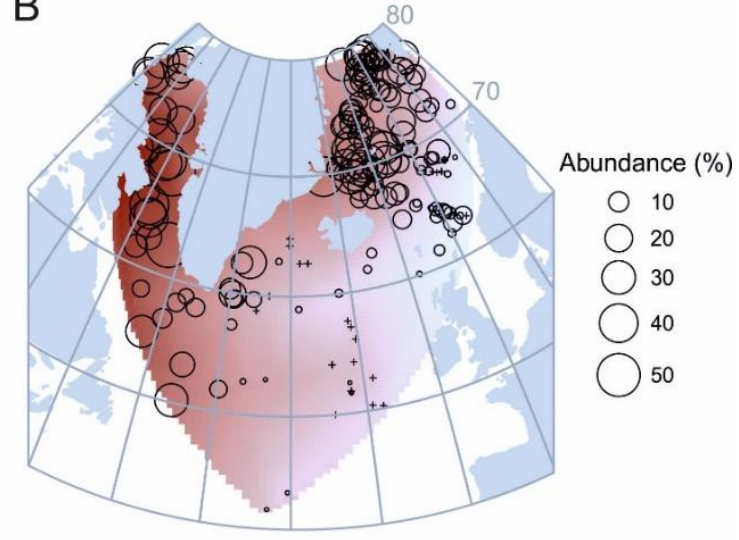

C
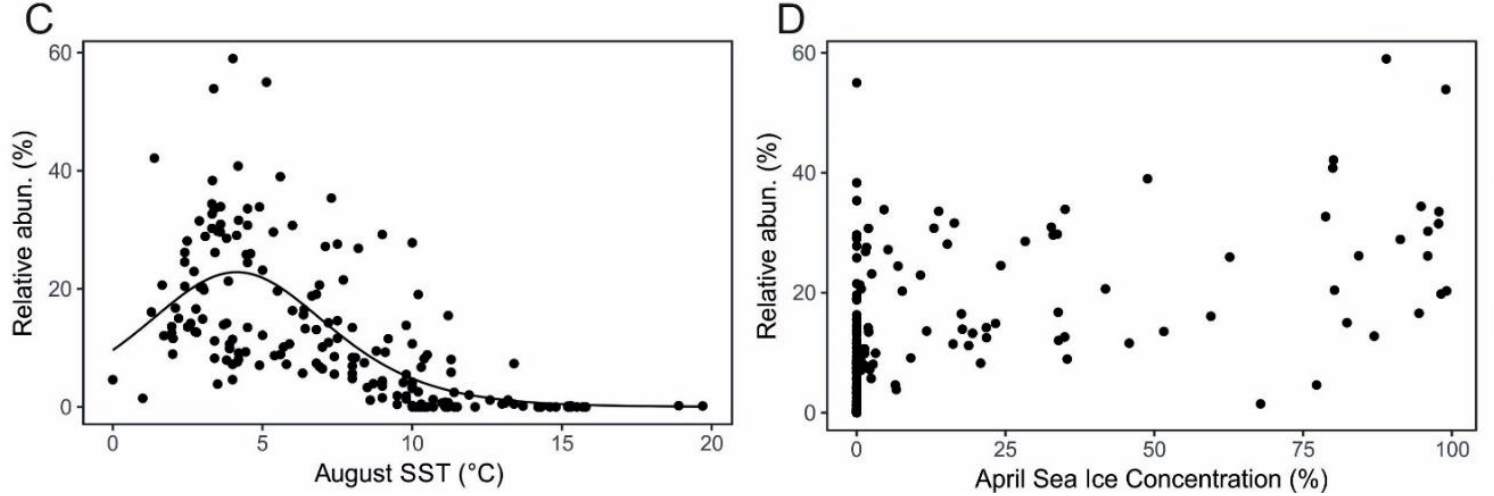

Figure 18. Thalassiosira antarctica var. borealis resting spore. a) Light microscopy images of the variety (sample from Baffin Bay, core SL-170), b) Geographical distribution (dark red shading indicates where abundances are highest, and symbol + refers to location with 0 abundances), c) Response to August SST, d) Response to April sea ice concentrations.

Thalassiosira antarctica Comber var. borealis resting spore (Fig. 18)

Synonyms. Thalassiosira antarctica var. borealis G. Fryxell, Doucette \& Hubbard: Thalassiosira fallax M eunier. References. Sancetta, 1982, p. 240, pl. 4, figs. 14-15; Hasle and Syvertsen, 1996, p. 66, pl. 8; Jensen, 2003, p. 120, pl. 7, figs. 5-9; Cremer, 1998, p. 77, pl. 38, figs 1-4. 
648 Response to environmental gradients. Temperature range from 0 to $19.7^{\circ} \mathrm{C}$, optimum $4.9^{\circ} \mathrm{C}$. Statistically 649 significant relationship to SST but not to sea ice (Fig. 18c, d).

650 Distribution. Very abundant in our dataset, excluding the SE North Atlantic region. Highest abundances are 651 found in Baffin Bay, Labrador Sea, Nordic Seas, Fram Strait and off East Greenland.

652 Previously published literature often discusses Thalassiosira gravida spore, yet Thalassiosira gravida does 653 not form resting spores (Hasle and Syvertsen, 1996) and the species described as Thalassiosira gravida spore 654 is likely Thalassiosira antarctica var. borealis resting spore. Thalassiosira antarctica var. borealis resting spore may also have in older studies been called Coscinodiscus subglobosus Cleve et Grunow in Grunow (Hasle and Syvertsen, 1996). Recently, spores with great resemblance to Thalassiosira antarctica var. borealis resting spore have been described as Thalassiosira kushirensis spore (e.g., Krawczyk et al., 2010; 2012; 2016), which has been associated with warmer (Atlantic-sourced) waters (Krawczyk et al., 2013). M ore recently, this ecological interpretation has been challenged and the Thalassiosira kushirensis spore was shown to be a coldwater indicator (Weckström et al., 2014), however, associated with slightly warmer summer surface water temperatures (Krawczyk et al., 2014).

Thalassiosira antarctica var. borealis resting spore (including spores previously named Thalassiosira gravida) has in previous literature been described as a cold-water taxon associated with Arctic waters and sea ice (Sancetta, 1981; Williams, 1984; 1986; Koç Karpuz and Schrader, 1990; De Sève, 1999; Jiang et al., 2001; Andersen et al., 2004b; Justwan and Koç, 2008). The Arctic Water assemblage in Andersen et al. (2004b) (Fig. 2) mainly consist of Thalassiosira antarctica var. borealis resting spore and it is also included as an important taxon in the Sea Ice/M arginal Ice Zone assemblage. It is common in the Arctic Ocean spring bloom, however, occurring later than the Fragilariopsis species and Fossula arctica (von Quillfeldt, 2000; 2003). Although T. antarctica var. borealis resting spore has previously been associated with sea ice, in our data set there is no clear relationship (Fig. 18d) and the taxon is abundant also in areas, which are ice-free year round (Fig. 18b). This spore is one of the most common North Atlantic taxa today and one of the most dominant constituent of fossil diatom assemblages during the Holocene (see references above) and beyond (e.g., Oksman et al., 2017b). Due to its importance for paleoclimate reconstructions, more detailed taxonomic work (including diatom cultures) are needed to resolve if the spores identified as either Thalassiosira gravida r.s. or Thalassiosira antarctica var. borealis r.s., and the spores described in Krawczyk et al. (2012) as Thalassiosira kushirensis r.s. are actually the same taxon, and further, if morphologically distinct spore types depending on water temperature can be defined. Finally, it has not been resolved which vegetative cell morphotype produces the (or these) spore(s). 

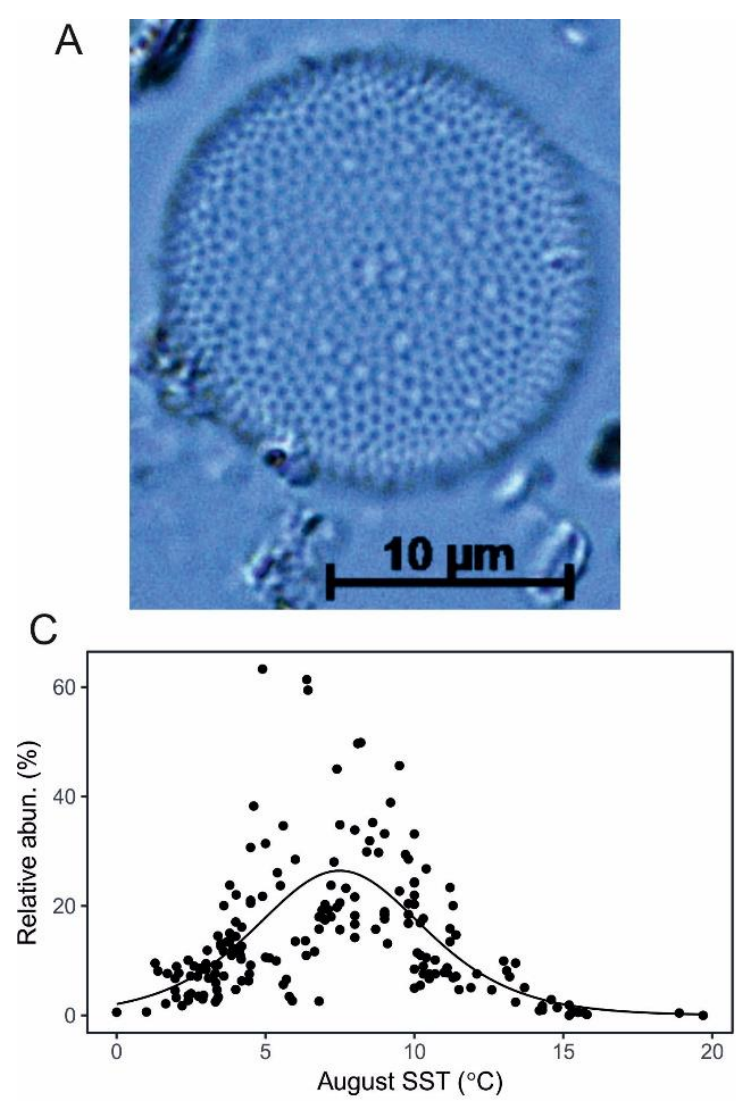
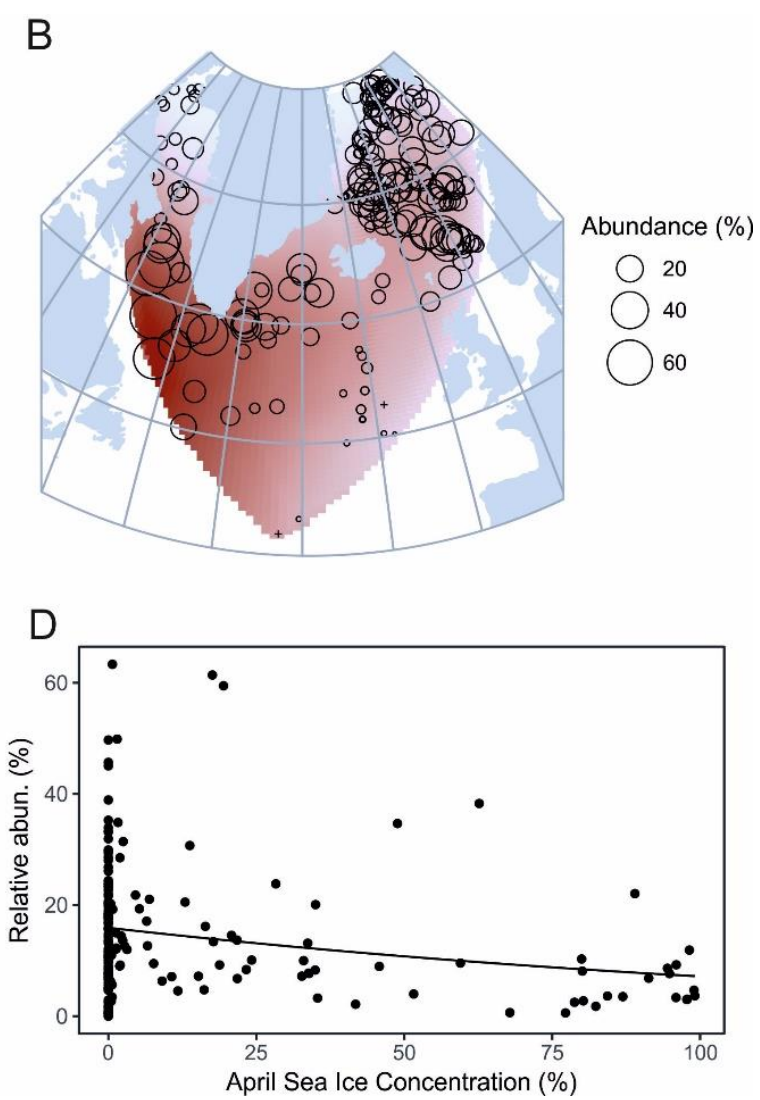

Figure 19. Thalassiosira gravida. a) Light microscopy image of the species (sample from Baffin Bay, core SL-170), b) Geographical distribution (dark red shading indicates where abundances are highest, and symbol + refers to location with 0 abundances), c) Response to August SST, d) Response to April sea ice concentrations.

Thalassiosira gravida Cleve (Fig. 19)

Synonym. Thalassiosira tcherniai M anguin.

References. Hasle and Syvertsen, 1996, p. 69, pl. 8; Cremer, 1998, p. 78, pl. 40, fig. 3; Bérard-Therriault et al., 1999, p. 24, pl. 7a, b, d-g; Scott and Thomas, 2005, p. 100, fig. 2.51; Pearce et al., 2014b, p. 452, figs. 57-58.

Response to environmental gradients. Temperature range from 0 to $18.9^{\circ} \mathrm{C}$, optimum $7.1^{\circ} \mathrm{C}$ (Fig. $19 \mathrm{C}$ ). Statistically significant response to SST and sea ice. Although found at relatively high abundances (10-20\%) at high sea ice concentrations ( $90-100 \%$ ), the species is clearly more common at sea ice concentrations $<50 \%$ (Fig. 19d).

Distribution. Thalassiosira gravida is very abundant in our dataset and was found in every sample, excluding two samples from the southern North Atlantic. Highest abundances (up to 60\%) are found in Davis Strait/northern Labrador Sea.

Thalassiosira gravida is described in literature as a cosmopolitan species, typical for northern cold water to temperate regions (Hasle and Syvertsen, 1996; Jiang et al., 2001). Thalassiosira gravida is the main contributor to the East-West Greenland Current assemblage (Fig. 2) that dominates subarctic waters of the Labrador Sea (Andersen et al., 2004b) and the main component in the Norwegian-Arctic Waters mixing assemblage, which is most common between the Atlantic and the Arctic water masses (Koç Karpuz and Schrader, 1990). Thalassiosira gravida has been used as an indicator of higher water temperatures (Jiang et al., 2001; Witak et al., 2005), but also as a cold water indicator (Pearce et al., 2014a; M iller and Chapman, 2013). This confusion may be caused by misidentifications, or it has not been clarified whether the identified valves are vegetative cells or resting spores. Thalassiosira gravida does not form resting spores (Hasle and Syvertsen, 1996), and the Thalassiosira gravida spores mentioned in literature are likely resting spores of 
Thalassiosira antarctica var. borealis. While the former prefers higher water temperatures (between ca. 5 and $10^{\circ} \mathrm{C}$ ), the latter is most abundant at SSTs at and below $5^{\circ} \mathrm{C}$ (Fig. $19 \mathrm{C}$ ).

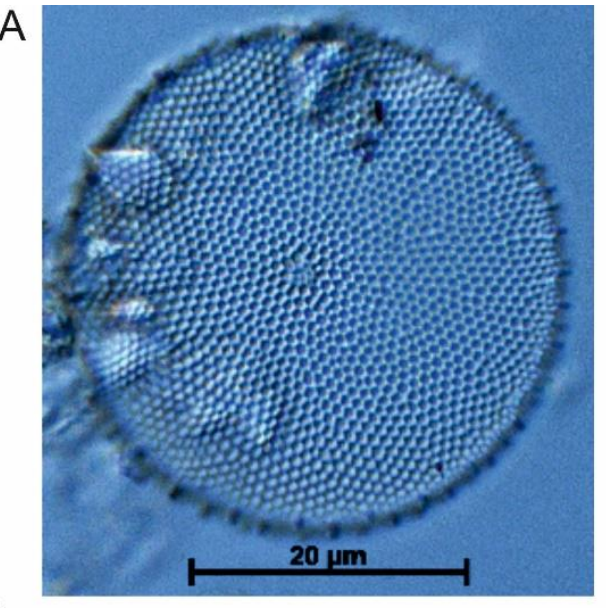

C

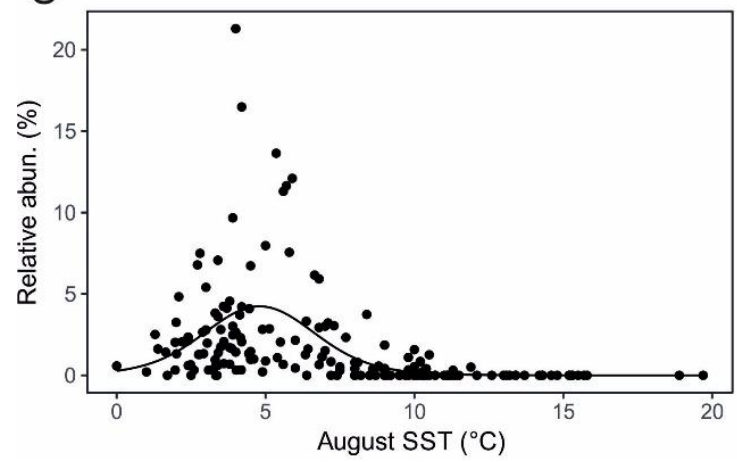

B
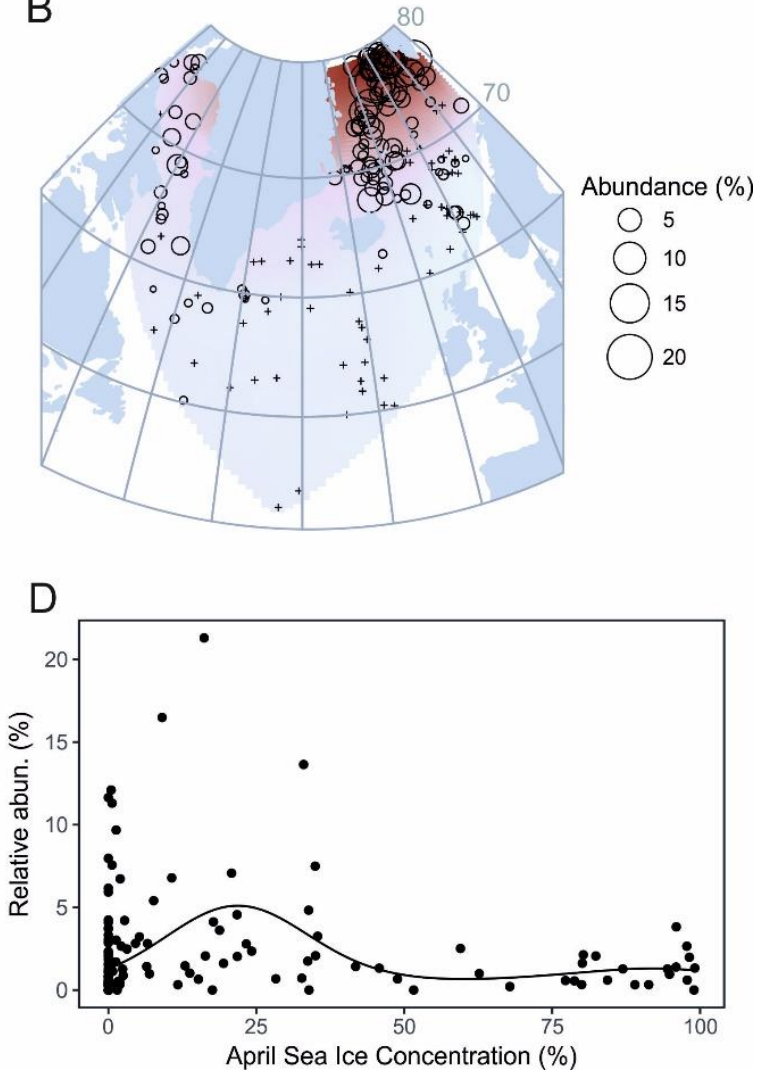

Figure 20. Thalassiosira hyalina. a) Light microscopy image of the species (sample from Southeast Greenland, core MD99-2322), b) Geographical distribution (dark red shading indicates where abundances are highest, and symbol + refers to location with 0 abundances), c) Response to August SST, d) Response to April sea ice concentrations.

Thalassiosira hyalina (Grunow) Gran (Fig. 20)

Basionym. Coscinodiscus hyalinus Grunow in Cleve \& Grunow.

References. Sancetta, 1982, p. 242, pl. 5, figs. 4-5; Metzeltin and Witkowski, 1996, p. 120; Hasle and Syvertsen, 1996, p. 69, pl. 8; Cremer, 1998, p. 78, pl. 40, figs. 1-2; Bérard-Therriault et al., 1999, p. 25, pl. 8ad; Pienitz et al., 2003, p. 16, pl. 3, fig. 4-5; Jensen, 2003, p. 122, pl. 9, figs. 3-5; Pearce et al., 2014b, p. 452, figs. 59-60.

Response to environmental gradients. Temperature range from 0 to $11.9^{\circ} \mathrm{C}$, optimum $4.7^{\circ} \mathrm{C}$. Statistically significant response to SST and sea ice (Fig. 20c, d).

Distribution. Thalassiosira hyalina mainly occurs at northern latitudes and the highest abundances in the dataset (up to 20\%) are found in Fram Strait, SW Svalbard, and the northern Nordic Seas.

Thalassiosira hyalina is described as an Arctic species and often associated with sea ice (Koç Karpuz and Schrader, 1990; Krawczyk et al., 2010; 2013; Andersen et al., 2004b). It is an important species in the Sea Ice/M arginal Ice Zone assemblage in Andersen et al. (2004b) (Fig. 2). Thalassiosira hyalina has been found to be a common species in the Arctic Ocean spring bloom (von Quillfeldt, 2000). In Baffin Bay, it characterizes the West Greenland Current assemblage described in Williams (1986), indicating relatively warm and saline waters and low sea ice concentrations along the southwest coast of Greenland. Based on our dataset, 
Thalassiosira hyalina is a cold-water species (most abundant at ca. $5^{\circ} \mathrm{C}$ ) thriving at relatively low (ca. $20 \%$ ) spring sea ice concentrations (Fig. 20b, c, d).
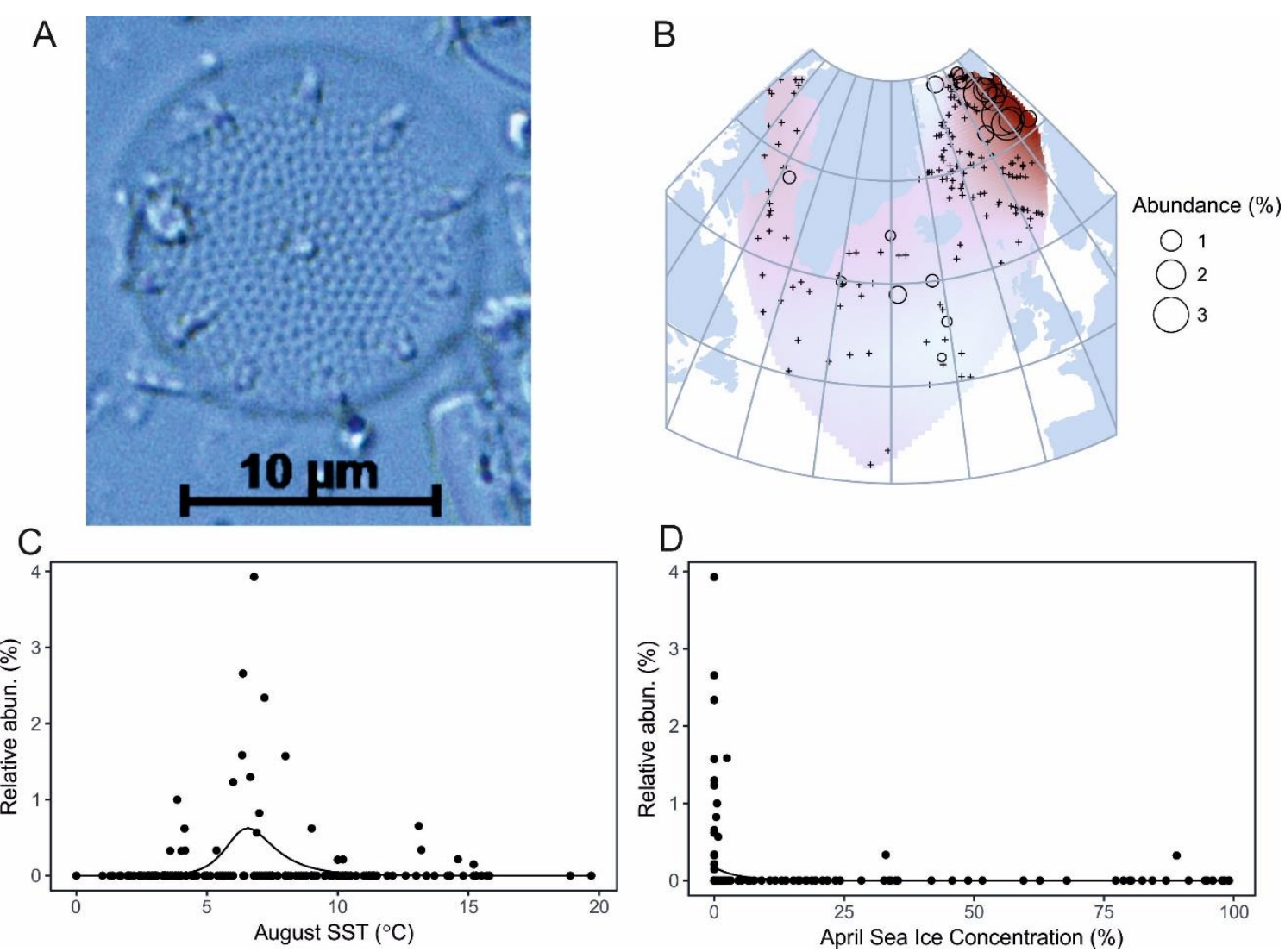

Figure 21. Thalassiosira nordenskioeldii. a) Light microscopy image of the species (sample from Baffin Bay, core SL-170), b) Geographical distribution (dark red shading indicates where abundances are highest, and symbol + refers to location with 0 abundances), c) Response to August SST, d) Response to April sea ice concentrations.

Thalassiosira nordenskioeldii Cleve (Fig. 21)

References. Sancetta, 1982, p. 243, pl. 5, figs. 8-9; M etzeltin and Witkowski, 1996, p. 118, 124; Hasle and Syvertsen, 1996, p. 56, pl. 5; Cremer, 1998, p. 79, pl. 39, figs. 2, 3; Bérard-Therriault et al., 1999, p. 26, pl. 8f, 9a-f; Jensen, 2003, p. 123, pl. 10, figs. 5-8; Pienitz et al., 2003, p. 17, pl. 3, fig. 6; Pearce et al., 2014b, p. 453, figs. 63-65.

Response to environmental gradients. Temperature range from 1 to $13.2^{\circ} \mathrm{C}$, optimum $7.1^{\circ} \mathrm{C}$. Statistically significant relationship to SST and sea ice (Fig. 21c, d).

Distribution. Based on our dataset, Thalassiosira nordenskioeldii is relatively rare in the northern North Atlantic. Highest abundances (up to only $3 \%$ ) are found between northern Norway and SW Svalbard, but the species occurs also in individual samples from Baffin Bay and S and SW of Iceland (Fig. 21b).

Thalassiosira nordenskioeldii is described in literature as a neritic temperate-Arctic species blooming in the spring (Von Quillfeldt, 2000; Jensen et al., 2004 and references therein). It is an important contributor to the Sea Ice/M arginal Ice Zone assemblage in Andersen et al. (2004b) (Fig. 2) that reflects the winter Arctic sea ice limit. However, in these seasonally ice-covered areas it blooms after the pennate Fragilariopsis spp. and Fossula arctica, and is considered a late spring bloom species, reaching highest abundances after ice break up. Thalassiosira nordenskioeldii has further been suggested to be one of the most widely distributed cold 
water diatom species in the North Atlantic and adjacent seas (Bérard-Therriault et al., 1999). The discrepancy between this statement and the distribution of T. nordenskioeldii in our dataset may stem from the fact that most of our sites are in the open ocean, whereas the species is associated with coastal (neritic) regions.

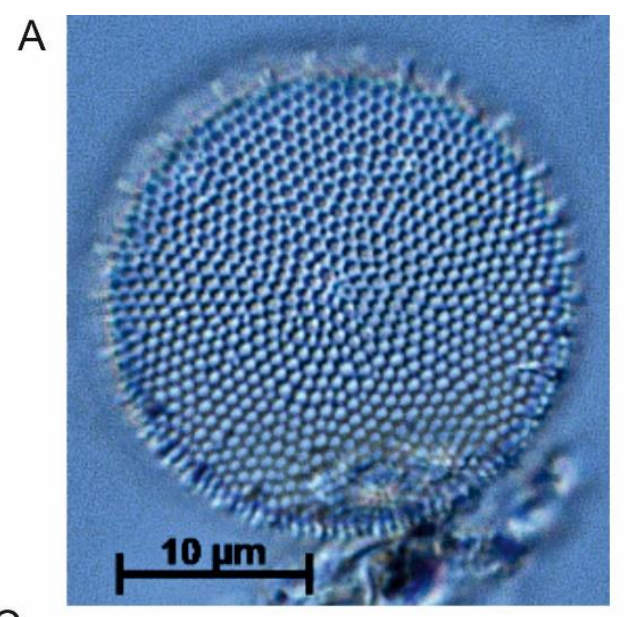

B
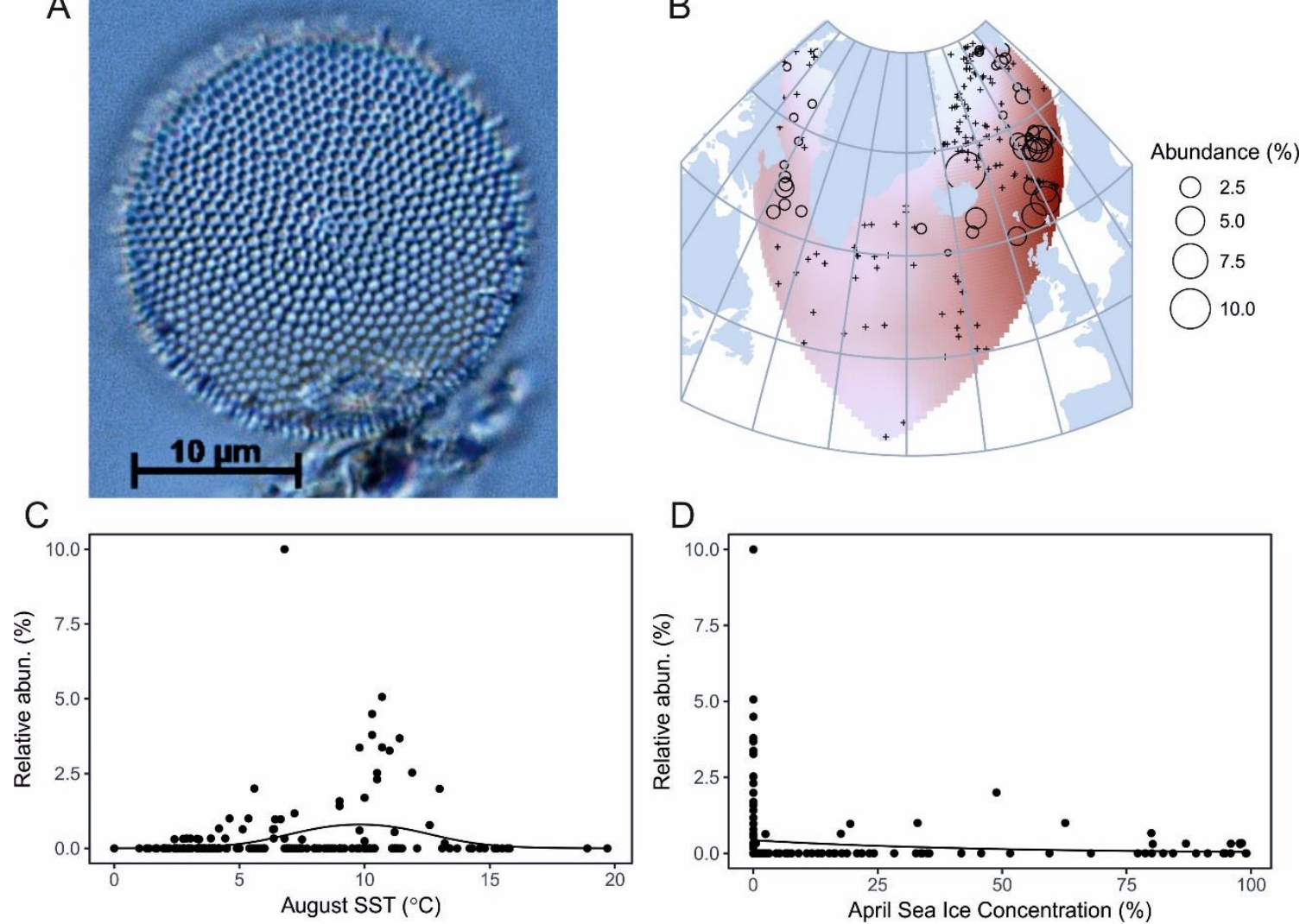

Figure 22. Thalassiosira pacifica. a) Light microscopy image of the species (sample from Southeast Greenland, core MD99-2322), b) Geographical distribution (dark red shading indicates where abundances are highest, and symbol + refers to location with 0 abundances), c) Response to August SST, d) Response to April sea ice concentrations.

Thalassiosira pacifica Gran \& Angst (Fig. 22)

References. Hasle and Syvertsen, 1996, p. 57, pl. 5; Bérard-Therriault et al., 1999, p. 27, pl. 8e, 10a-g; Pienitz et al., 2003, p. 18, pl. 4, figs. 1-6; Pearce et al., 2014b, p. 453, fig. 68.

Response to environmental gradients. Temperature range from 2.4 to $13.2^{\circ} \mathrm{C}$, optimum $9.0^{\circ} \mathrm{C}$. Statistically significant relationship to SST and sea ice (Fig. 22c, d).

Distribution. M ost abundant in our dataset north of Iceland and in the Norwegian Sea (up to 10\%), also found at low abundances in Baffin Bay and Davis Strait.

Thalassiosira pacifica is described in literature as a cold- to temperate-water species restricted to the Northern hemisphere; it is most abundant along the coasts of the Pacific Ocean (von Quillfeldt, 2000; Jensen, 2004). Thalassiosira pacifica could be defined as a temperate species more common in permanently ice-free regions. 

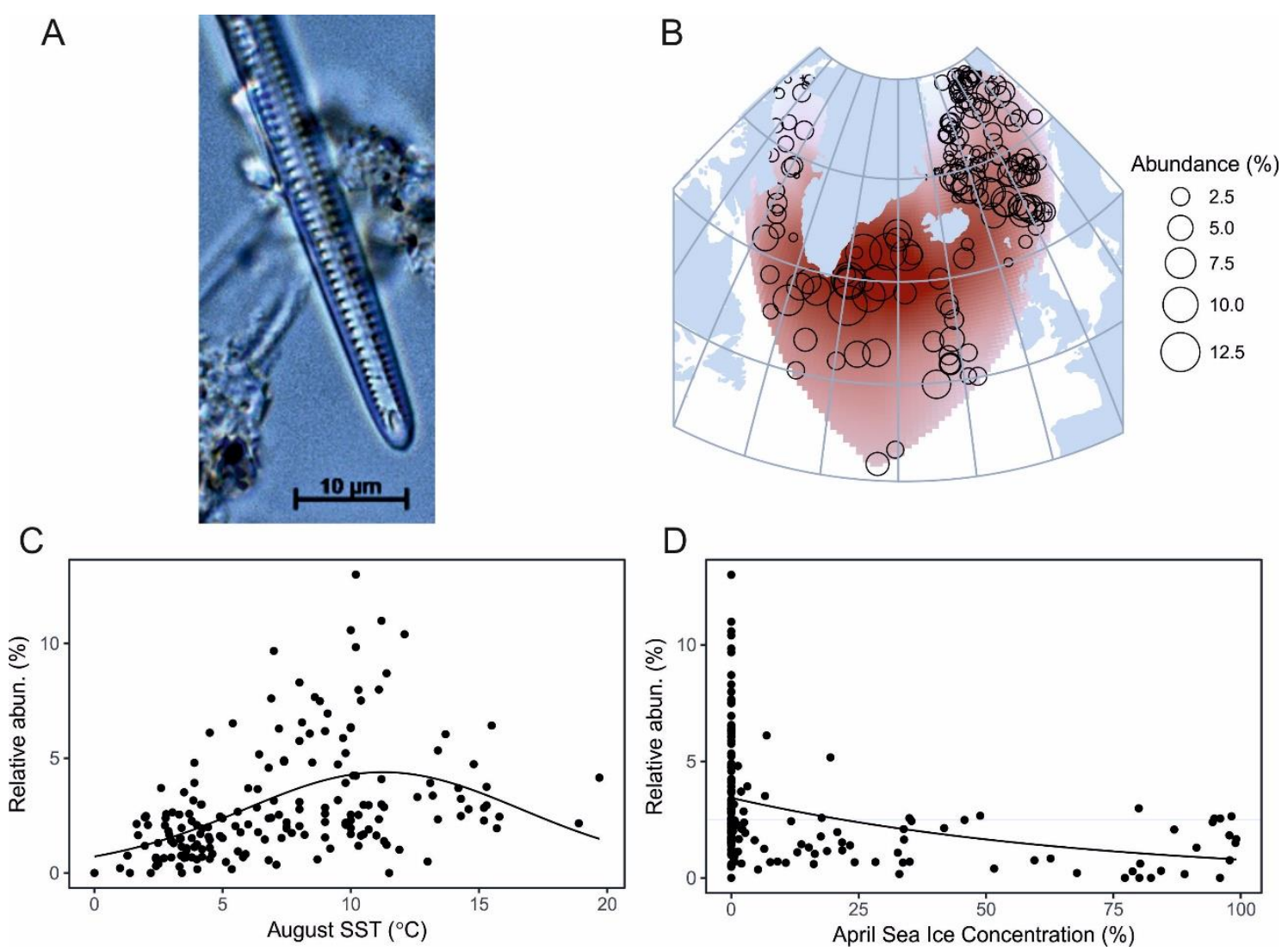

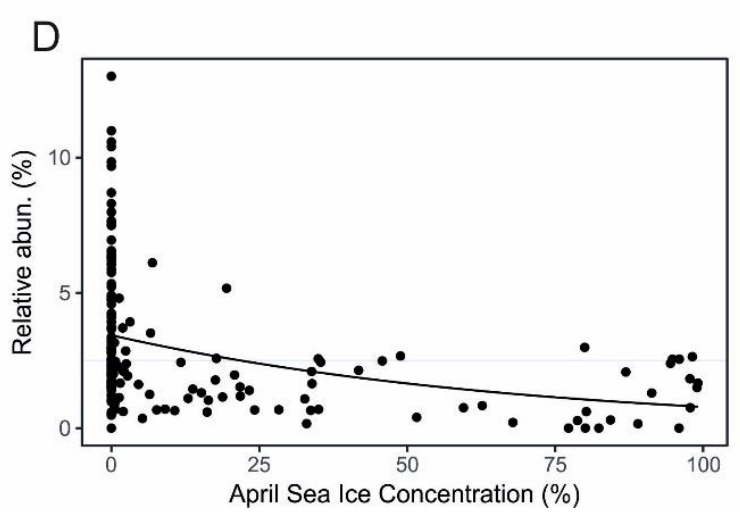

Figure 23. Thalassiotrix longissima. a) Light microscopy image of the species (sample from Baffin Bay, core SL-170), b) Geographical distribution (dark red shading indicates where abundances are highest, and symbol + refers to location with 0 abundances), c) Response to August SST, d) Response to April sea ice concentrations.

Thalassiothrix longissima (Cleve) Cleve \& Grunow (Fig. 23)

Basionym. Synedra thalassiothrix Cleve

References. Sancetta, 1982, p. 245, pl. 6, figs. 3-4; Hasle and Syvertsen, 1996, p. 263, pl. 58 and 59; Cremer, 1998, p. 79; Bérard-Therriault et al., 1999, p. 58, pl. 48c, f; Jensen, 2003, p. 130, pl. 12, fig. 9; Pearce et al., 2014b, p. 453, figs. 69-70.

Response to environmental gradients. Temperature range from 1 to $19.7^{\circ} \mathrm{C}$, optimum $8.6^{\circ} \mathrm{C}$ (Fig. $23 \mathrm{C}$ ). Statistically significant relationship to both SST and sea ice. Relatively similar concentrations (3-4\%) between 25 and 100\% sea ice concentration, most abundant (ca. 10\%) in ice-free areas (Fig. 23d).

Distribution. Very common species in the Northern Hemisphere found in almost every sample of the dataset. Highest abundances off SE Greenland, around Iceland and in the Nordic Seas.

Thalassiothrix longissima is described as a typical species in the Arctic/subarctic to northern temperate region (Hasle and Syvertsen, 1996). In the Labrador Sea, it has been used as an indicator of Atlantic Water inflow, because it is associated with the Irminger Current, the warm and saline component of the West Greenland Current (De Sève, 1999). In the Nordic Seas, it is abundant where Arctic and Atlantic water masses mix and contributes to the Arctic-Norwegian Waters M ixing Assemblage (Koç Karpuz and Schrader, 1990). On a North Atlantic scale, it belongs to the Sub-Arctic Waters assemblage (Fig. 2; Andersen et al. 2004b). Thalassiothrix longissima does not have a well-defined SST optimum but is most abundant around SSTs of $10^{\circ} \mathrm{C}$ (Fig. 23C). 


\section{Concluding remarks}

In this study, we presented the geographic distributions of diatom species frequently found in present-day and fossil diatom assemblages in the northern North Atlantic, and their responses to key environmental variables (SST and sea ice concentrations). The results will promote ecologically sound and harmonized use of diatoms as paleoclimate proxies in the region.

All species in the dataset have a statistically significant relationship with aSST. This is important as the dataset Was originally developed for quantitative SST reconstructions (e.g., Oksman et al. 2017b). The most abundant
taxa in the studied dataset are Thalassiosira gravida, Thalassiosira antarctica var, borealis resting spore and taxa in the studied dataset are Thalassiosira gravida, Thalassiosira antarctica var. borealis resting spore and Rhizosolenia hebetata f. semispina, whereas the most common species (present in most surface samples) are Thalassiosira gravida, Thalassiothrix longissima and Rhizosolenia hebetata f. semispina. The results suggest that Actinocyclus curvatulus, Bacteriosira bathyomphala spore, Fragilariopsis cylindrus, Fragilariopsis oceanica, Porosira glacialis, Rhizosolenia hebetata f. hebetata, Shionodiscus trifultus, Thalassiosira angustelineata, Thalassiosira antarctica var. borealis resting spore, Thalassiosira nordenskioeldii and Thalassiosira hyalina are robust indicators of cold waters. Coscinodiscus radiatus, Thalassionema nitzschioides and Shionodiscus oestrupii are reliable indicators for warmer waters, and Thalassiothrix longissima, Thalassiosira angulata, Thalassiosira gravida, Rhizosolenia hebetata f. semispina and Thalassiosira pacifica indicate temperate waters.

The sea ice response models show a statistically significant relationship with sea ice for 15 species (Table 1). Some of these findings challenge previous ecological interpretations as species used as sea ice indicators, e.g., Fragilariopsis cylindrus and Bacterosira bathyomphala spore (e.g., Krawczyk et al. 2010) did not show statistically significant relationships with sea ice over the large geographic coverage of our dataset, and thus their use as sea ice indicators should be carefully considered. The reliability of Fragilariopsis cylindrus as an indicator for sea ice has been previously discussed in von Quillfeldt (2004), where it was pointed out that F. cylindrus can also dominate phytoplankton blooms in areas never experiencing sea ice. According to von Quillfeldt (2004) its potential as a sea ice indicator seems to vary between regions, but the species is a very good indicator of cold water. Caution should be exercised with species such as Rhizosolenia hebetata f. hebetata, Shionodiscus trifultus and Thalassiosira antarctica var. borealis resting spore, as they are relatively abundant in seasonally ice-covered areas, but do not exhibit statistically significant relationships with sea ice concentrations, occurring abundantly also in ice-free conditions. The results imply that out of the 21 studied species, Actinocyclus curvatulus, Fragilariopsis oceanica and Porosira glacialis are the most robust sea ice indicators, as they have a statistically significant relationship with April sea ice concentrations and exhibit highest abundances at high sea ice concentrations. Reversely, species displaying a statistically significant relationship to sea ice occurring most abundantly at low (down to $0 \%$ ) sea ice concentrations - Coscinodiscus radiatus, Shionodiscus oestrupii, Thalassionema nitzschioides, Thalassiosira angulata and Thalassiosira pacifica - hold the potential for being indicators of (near) ice-free conditions. Rhizosolenia hebetata f. semispina, Thalassiothrix longissima, Thalassiosira anguste-lineata, Thalassiosira gravida, and Thalassiosira hyalina all have a statistically significant relationship to sea ice, occurring most abundantly at relatively low sea ice concentrations. 
This study highlights the importance of understanding the species-specific and region-specific ecologies of diatoms used in paleoclimate reconstruction. It further identifies challenges that can be related to taxonomic problems (here regarding Thalassiosira antarctica var. borealis resting spore). These types of identification issues need to be resolved in the future as they can strongly affect ecological interpretations and may ultimately lead to false climate reconstructions based on fossil diatom assemblages. The high-quality light microscopy images and the assessment of main environmental preferences of North Atlantic diatom species will promote harmonized species identification and sound ecological interpretation. This will aid comparability and strengthen diatom-based reconstructions from the region.

\section{Acknowledgements}

We thank M. Heikkilä, C. Pearce, A. Pieńkowski, X. Crosta and K. Pauli for discussion and valuable comments that improved this manuscript. M. Oksman acknowledges funding from the Finnish Graduate School in Geology.

\section{References}

Andersen, C.N., Koç, N., Jennings, A., Andrews, J.T., 2004a. Nonuniform response to the major surface currents in the Nordic Seas to insolation forcing: Implications for the Holocene climate variability. Paleoceanography 19, PA2003, doi:10.1029/2002PA000873.

Andersen, C.N., Koç, N., M oros, M., 2004b. A highly unstable Holocene climate in the subpolar North Atlantic: evidence from diatoms. Quat. Sci. Rev. 23, 2155-2166.

Bérard-Therriault, L., Poulin M., Bossé, L., 1999. Guide d'identification du phytoplancton marin de l'estuaire et du golfe du Saint-Laurent: incluant également certains proto-zoaires. NRC Research Press, Ottawa.

Berner, K.S., Koç, N., Divine, D., Godtliebsen, F., M oros, M., 2008. A decadal-scale Holocene sea surface temperature record from the subpolar North Atlantic constructed using diatoms and statistics and its relation to other climate parameters. Paleoceanography, 23, PA2210, doi:10.1029/2006PA001339.

Berner, K.S., Koç, N., Godtliebsen, F., Divine, D., 2011. Holocene climate variability of the Norwegian Atlantic Current during high and low solar insolation forcing. Paleoceanography 26, PA2220, doi:10.1029/2010PA002002.

Birks, C.J.A., 2001. A Younger Dryas-Holocene diatom record of sea surface temperatures and oceanographic changes from core MD95-2011, Vøring Plateau. M.Sc. thesis, University of Bergen, 171 pp.

Birks, C.J.A., Koç, N., 2002. A high-resolution diatom record of late-Quaternary sea-surface temperatures and oceanographic conditions from the eastern Norwegian Sea. Boreas 31, 323-344.

Caissie, B.A., 2012. Diatoms as Recorders of Sea Ice in the Bering and Chukchi Seas: Proxy Development and Application. Open Access Dissertations Paper 547.

Cavalieri, D., Parkinson, C., Gloersen, P. and Zwally, H.J., 1996. Sea Ice Concentrations from Nimbus-7 SM M R and DMSP SSM /I-SSM IS Passive Microwave Data, NASA DAAC at the National Snow and Ice Data Center, Boulder Colorado.

Cremer, H., 1998. The diatom flora of the Laptev Sea (Arctic Ocean). J. Cramer, Berlin \& Stuttgart.

De Sève, M.A., 1999. Transfer function between surface sediment diatom assemblages and sea-surface temperature and salinity of the Labrador Sea. Mar. Micropal. 36, 249-267. 
Fetterer, F., Knowles, K., M eier, W., Savoie, M., 2017 updated daily. Sea ice index, version 2.1. Arctic monthly median extent. Boulder, Colorado USA. NSIDC: National Snow and Ice Data Center (accessed 27 July 2017).

Hasle, G.R., Syvertsen, E.E., 1996. Marine diatoms. In: Identifying marine phytoplankton (Ed. by C.R. Tomas), pp.5-385. Academic Press, California.

Holland, D.M., Thomas, R.H., de Young, B., Ribegaard, M.H., Lyberth, B., 2008. Acceleration of Jakobshavn Isbræ triggered by warm subsurface ocean waters. Nat. Geosci. 1, 659-664.

Huisman, J., Olff, H., Fresco, L.F.M., 1993. A hierarchical set of models for species response analysis. J. Veg. Sci. 4, 37-46.

Imbrie, J. and Kipp, N.G., 1971. Late Cenozoic Glacial Ages, 71-181 (Yale University press, 1971).

Jansen F., Oksanen J., 2013. How to model species responses along ecological gradients - Huisman-Olff-Fresco models revisited. J. Veg. Sci. 24, 1108-1117.

Jensen, K.G., 2003. Holocene hydrographic changes in Greenland coastal waters: Reconstructing environmental change from sub-fossil and contemporary diatoms: Ph.D. Thesis. Botanical Institute, Faculty of Science, University of Copenhagen.

Jensen, K.G., Kuijpers, A., Koç, N., Heinemeier, J., 2004. Diatom evidence of hydrographic changes and ice conditions in Igaliku Fjord, South Greenland, during the past 1500 years. The Holocene 14, 152-164.

Jiang, H., Seidenkrantz, M.-S., Knudsen, K.L., Eiríksson, J., 2001. Diatom surface sediment assemblages around Iceland and their relationship to oceanic environmental variables. Mar. M icropal. 41, 73-96.

Jiang, H., Seidenkrantz, M.-S., Knudsen, K.L., Eiríksson, J., 2002. Late-Holocene summer sea-surface temperatures based on a diatom record from the north Icelandic shelf. The Holocene 12(2), 137-147.

Jiang, H., Eiríksson, J., Schulz, M., Knudsen, K.L., Seidenkrantz, M.-S., 2005. Evidence for solar forcing of seasurface temperature on the North Icelandic Shelf during the late Holocene. Geology 33 (1), 73-76.

Jiang, H., M uscheler, R., Björck, S., Seidenkrantz, M.-S., Olsen, J., Sha, L., Sjolte, J., Eiríksson, J., Ran, L., Knudsen, K.L., Knudsen, M.F., 2015. Solar forcing of Holocene summer sea surface temperatures in the northern North Atlantic. Geology 43 (3), 203-206.

Justwan, A., Koç, N., 2008. A diatom based transfer function for reconstructing sea ice concentrations in the North Atlantic. Mar. Micropal. 66, 264-278.

Justwan, A., Koç, N., Jennings, A.E., 2008. Evolution of the Irminger and East Iceland Current systems through the Holocene, revealed by diatom-based sea surface temperature reconstructions. Quat. Sci. Rev. 27, 1571-1582.

Justwan, A., Koç, N., 2009. Evolution of the East Greenland Current between 1150 and 1740 AD, revealed by diatom-based sea surface temperature and sea-ice concentration reconstructions. Polar Res. 28, 165-176.Koç Karpuz, N., Schrader, H., 1990. Surface sediment diatom distribution and Holocene paleotemperature variations in the Greenland, Iceland and Norwegian Sea.

Paleoceanography 5, 557-580.

Koç, N., Jansen, E., Haflidason, H., 1993. Paleoceanographic reconstruction of surface ocean conditions in the Greenland, Iceland and Norwegian Seas through the last 14 ka based on diatoms, Quaternary Science Reviews 12, 115-140.

Koç, N., Jansen, E., 1994. Response of the high-latitude Northern Hemisphere to orbital climate forcing: Evidence from the Nordic Seas. Geology 22, 523-526. 
Koç, N., Klitgaard-Kristensen, D., Hasle, K., Forsberg, C.F., Solheim, A., 2002. Late glacial paleoceanography of Hinlopen Strait, northern Svalbard. Polar Res. 21(2), 307-314.

Krawczyk, D.W., Witkowski, A., Moros, M., Lloyd, J., Kuijpers, A., Kierzek, A., 2010. Late-Holocene diatominferred reconstruction of temperature variations of the West Greenland Current from Disko Bugt, central West Greenland. The Holocene 20 (5), 659-666.

Krawczyk, D.W., Witkowski, A., Wroniecki, M., Waniek, J., Kurzydłowski, K.J., Płociński, T., 2012. Reinterpretation of two diatom species from the West Greenland margin - Thalassiosira kushirensis and Thalassiosira antarctica var. borealis - hydrological consequences. Mar. Micropaleontol. 88-89, 1-14.

Krawczyk, D.W., W itkowski, A., Lloyd, J., M oros, M., Harff, J., Kuijpers, A., 2013. Late-Holocene diatom derived seasonal variability in hydrological conditions off Disko Bay, West Greenland. Quat. Sci. Rev. 67, 93-104.

Krawczyk, D.W., Witkowski, A., Waniek, J.J., Wroniecki, M., Harff, J., 2014. Description of diatoms from the Southwest to West Greenland coastal and open marine waters. Polar Biol. 37, 1589- 1606.

Krawczyk, D.W., Witkowski, A., Moros, M., Lloyd, J.M., Høyer, J.L., M iettinen, A., Kuijpers, A., 2016. Quantitative reconstruction of Holocene sea ice and surface temperature off West Greenland from the first regional diatom data set. Paleoceanography 32 (1), 18-40.

Kwok, R., Cunningham, G.F., 2015. Variability of Arctic sea ice thickness and volume from CryoSat-2. Philos. Trans. Royal Soc. A 373 (2045), doi: 10.1098/rsta.2014.0157.

Metzeltin, D., Witkowski, A., 1996. Diatomeen der Bären-Insel: Süsswasser- und marine Arten. Koeltz Scientific Books, Königstein.

M iettinen, A., Koç, N., Hall, I.R., Godtliebsen, F., Divine, D., 2011. North Atlantic sea surface temperatures and their relation to the North Atlantic Oscillation during the last 230 years. Clim. Dyn. 36, 533-543.

M iettinen, A., Divine, D., Koç, N., Godtliebsen, F., Hall, I.R., 2012. M ulticentennial variability of the sea surface temperature gradient across the subpolar North Atlantic over the last 2.8 kyr. J. Clim. 25 (12), 4205-4219.

Miettinen, A., Divine, D.V., Husum, K., Koç, N., Jennings, A., 2015. Exceptional ocean surface conditions on the SE Greenland shelf during the Medieval Climate Anomaly. Paleoceanography 30, 1657-1674.

Miller, K.R., Chapman, M.R., 2013. Holocene climate variability reflected in diatom-derived sea surface temperature records from the subpolar North Atlantic. The Holocene 23 (5), 882-997.

Oksman, M., Weckström, K., M iettinen, A., Ojala, A.E.K., Salonen, V.P., 2017a. Late Holocene shift towards enhanced oceanic variability in a High Arctic Svalbard fjord $\left(79^{\circ} \mathrm{N}\right)$. Arktos $3: 4$, doi:10.1007/s41063-017-0032-9.

Oksman, M., Weckström, K., M iettinen, A., Juggins, S., Divine, D.V., Jackson, R., Telford, R., Korsgaard, N.J., Kucera, M., 2017b. Younger Dryas ice margin retreat triggered by ocean surface warming in central-eastern Baffin Bay. Nat. Commun. 8:1017, doi:10.1038/s41467-017-01155-6.

Parkinson, C.L., Cavalieri, D.J., 2008. Arctic sea ice variability and trends, 1979-2006. J. Geophys. Res. 113, C07003.

Parkinson, C.L., 2014. Spatially mapped reductions in the length of the Arctic sea ice season. Geophys. Res. Lett. 41 (12), 4316- 4322.

Pearce, C., Seidenkrantz, M.-S., Kuijpers, A., Reynisson, N.F., 2014a. A multi-proxy reconstruction of oceanographic conditions around the Younger Dryas-Holocene transition in Placentia Bay, Newfoundland. Mar. Micropal. 112, 39-49. 
Pearce, C., Weckström, K., Sha, L., M iettinen, A., Seidenkrantz, M.-S., 2014b. The Holocene marine diatom flora of Eastern Newfoundland bays. Diatom Res. 29, 441-454.

Pienitz, R., Fedje, D., Poulin, M., 2003. Marine and non-marine diatoms from the Haida Gwaii Archipelago and surrounding coasts, Northeastern Pacific, Canada. Gebruder Borntraeger Verlagsbuchhandlung, Science Publishers, Berlin \& Stuttgart.

Pike, J., Crosta, X., M addison, E.J ., Stickley, C.E., Denis, D., Barbara, L., Renssen, H., 2009. Observations on the relationship between the Antarctic coastal diatoms Thalassiosira antarctica Comber and Porosira glacialis (Grunow) Jørgensen and sea ice concentrations during the late Quaternary. Mar. Micropal. 73 (1-2), 14-25.

Pithan, F., M auritsen, T., 2014. Arctic amplification dominated by temperature feedbacks in contemporary climate models. Nat. Geosci. doi:10.1038/ NGEO2071.

R Core Team, 2017. R: A language and environment for statistical computing. R Foundation for Statistical Computing, Vienna, Austria. URL https://www.R-project.org/.

Ren, J., Jiang, H., Seidenkrantz, M.-S., Kuijpers, A., 2009. A diatom-based reconstruction of Early Holocene hydrographic and climate change in a southwest Greenland fjord. M ar. M icropal. 70, 166-176.

Ren, J., Gersonde, R., Esper, O., Sancetta, C., 2014. Diatom distributions in northern North Pacific surface sediments and their relationship to modern environmental variables. Palaeogeograp. Palaeoclimatol. Palaeoecol. 402, 81-103.

Sancetta, C., 1981. Oceanographic and ecological significance of diatoms in surface sediments of the Bering and Okhotsk Seas. Deep-Sea Research 28, 789-817.

Sancetta, C., 1982. Distribution of Diatom Species in Surface Sediments of the Bering and Okhotsk Seas. Micropaleontology 28, 221-257.

Scott, F.J., Thomas D.P., 2005. Diatoms. In: Antarctic marine protists (Ed. by F. J. Scott \& H. J. M archant), pp. 13-201. Australian Biological Resources Study, Canberra.

Sha, L., Jiang, H., Seidenkrantz, M.-S., Knudsen, K.L., Olsen, J., Kuijpers, A., Liu, Y., 2014. A diatom-based seaice reconstruction for the Vaigat Strait (Disko Bugt, West Greenland) over the last $5000 \mathrm{yr}$. Palaeogeograp. Palaeoclimatol. Palaeoecol. 403, 66-79.

Sha, L., Jiang, H., Seidenkrantz, M.-S., M uscheler, R., Zhang, X., Knudsen, M .F., Olsen, J., Knudsen, K.L., Zhang, W., 2016. Solar forcing as an important trigger for West Greenland sea-ice variability over the last millennium. Quat. Sci. Rev. 131, 148-156.

Sha, L., Jiang, H., Seidenkrantz, M.-S., Li, D., Andresen, C.S., Knudsen, K.L., Liu, Y., Zhao, M ., 2017. A record of Holocene sea-ice variability off West Greenland and its potential forcing factors. Palaeogeograp. Palaeoclimatol. Palaeoecol. 475, 115-124.

Snoeijs, P., Balashova, N., 1998. Intercalibration and distribution of diatom species in the Baltic Sea. Volume 5. Opulus Press, Uppsala.

Snoeijs, P., Kasperovičiene, J., 1996. Intercalibration and distribution of diatom species in the Baltic Sea. Volume 4. Opulus Press, Uppsala.

Snoeijs, P., Vilbaste, S., 1994. Intercalibration and distribution of diatom species in the Baltic Sea. Volume 2. Opulus Press, Uppsala.

Stephens, C.J., Antonov, I., Boyer, T.P., Conkright, M.E., Locarnini, R.A., O Brien, T.D., Garcia, H.E., 2002. In World Ocean Atlas 2001, Volume 1: Temperature, NOAA Atlas NESDIS, vol. 49, edited by S. Levitus, 167 pp., U.S. Gov. Print. Off., Washington D.C.

ter Braak, C.J.F., Looman, C.W.N., 1986. Weighted averaging, logistic regression and the Gaussian response model. Vegetatio 65, 3-11. 
Tuovinen, N., Weckström, K, Virtasalo, J.J., 2009. Assessment of recent eutrophication and climate influence in the Archipelago Sea based on the subfossil diatom record. Journal of Paleolimnology 44, 95-108.

von Quillfeldt, C.H., 2000. Common Diatom Species in Arctic Spring Blooms: Their Distribution and Abundance. Botanica M arina 43, 499-516.

von Quillfeldt, C.H., 2001. Identification of some easily confused diatom species in Arctic spring blooms. Botanica M arina 44, 375-389.

von Quillfeldt, C.H., Ambrose, W.G.Jr., Clough, L.M., 2003. High number of diatom species in first-year ice from the Chukchi Sea. Polar Biol. 26, 806-818.

von Quillfeldt, C.H., 2004. The diatom Fragilariopsis cylindrus and its potential as an indicator species for cold water rather than for sea ice. Vie M ilieu, 54(2-3), 137-143.

Weckström, K., Massé, G., Collins, L.G., Hanhijärvi, S., Bouloubassi, I., Sicre, M.-A., Seidenkrantz, M.-S., Schmidt, S., Andersen, T.J., Andersen, M.L., Hill, B., Kuijpers, A., 2013. Evaluation of the ice proxy $\mathrm{IP}_{25}$ against observational and diatom proxy data in the SW Labrador Sea. Quat. Sci. Rev. 79, 53-62.

Weckström, K., M iettinen, A., Caissie, B., Pearce, C., Ellegaard M., Krawczyk, D., Witkowski, A., 2014. Sea surface temperatures in Disko Bay during the Little Ice Age - caution needs to be exercised before assigning Thalassiosira kushirensis resting spore as a warm-water indicator in palaeoceanographic studies. Quat. Sci. Rev. 101, 234-237.

Williams, K.M., 1984. Marine diatom assemblages from Baffin Bay and Davis Strait. M.Sc. Thesis, Univ. Colorado, Boulder, CO, $111 \mathrm{pp}$.

Williams, K.M., 1986. Recent Arctic marine diatom assemblages from bottom sediments in Baffin Bay and Davis Strait. M ar. M icropal. 10, 327-341.

Williams, K.M., 1990. Late Quaternary paleoceanography of the western Baffin Bay region: evidence from fossil diatoms. Can. J. Earth Sci. 27, 1487-1494.

Williams, K.M, 1993. Ice sheet and ocean interactions, margin of the East Greenland ice sheet (14 ka to present): diatom evidence. Paleoceanography 8(1), 69-83.

Witak, M., Wachnicka, A., Kuijpers, A., Troelstra, S., Prins, M .A., Witkowski, A., 2005. Holocene North Atlantic surface circulation and climatic variability: evidence from diatom records. The Holocene 15 (1), 85-96.

Witkowski, A.W., Lange-Bertalot, H., Metzeltin, D., 2000. Diatom flora of marine coasts. A.R.G. Gantner. Ruggell.

Xiao, X., Zhao, M., Knudsen, K.L., Sha, L., Eiríksson, J., Gudmundsdóttir, Jiang, H., Guo, Z., 2017. Deglacial and Holocene sea-ice variability north of Iceland response to ocean circulation changes. Earth Planet. Sci. Lett. 472, 14-24.

Årthun, M., Eldevik, T., Viste, E., Drange, H., Furevik, T., Johnson, H.L., Keenlyside, N.S., 2016. Skillful prediction of northern climate provided by the ocean. Nat. Comm. 8:15875, doi: 10.1038/ncomms15875.

\section{Appendix 1.}


1077 Surface sediment sample locations, water depth (m), modern August SST $\left({ }^{\circ} \mathrm{C}\right)$, modern April sea ice 1078 concentration (\%) and sampling year.

\begin{tabular}{|c|c|c|c|c|c|c|}
\hline Sample & Latitude & Longitude & Water depth (m) & $\mathrm{SST}\left({ }^{\circ} \mathrm{C}\right)$ & Sea ice (\%) & Sampling year \\
\hline $71-12$ & $68^{\circ} 25.70^{\prime} \mathrm{N}$ & $13^{\circ} 52.20^{\prime} \mathrm{W}$ & 1633 & 5.5 & 0 & pre-1990 \\
\hline $71-17$ & $70^{\circ} 00.39^{\prime} \mathrm{N}$ & $13^{\circ} 01.09^{\prime} \mathrm{W}$ & 1460 & 4.9 & 4.6 & pre-1990 \\
\hline $71-21$ & $69^{\circ} 57.30^{\prime} \mathrm{N}$ & $06^{\circ} 09.70^{\prime} \mathrm{W}$ & 2612 & 7.7 & 0 & pre-1990 \\
\hline $71-26$ & $67^{\circ} 20.10^{\prime} \mathrm{N}$ & $02^{\circ} 09.90^{\prime} \mathrm{E}$ & 1486 & 10.2 & 0 & pre-1990 \\
\hline $71-19$ & $69^{\circ} 28.99^{\prime} \mathrm{N}$ & $09^{\circ} 30.60^{\prime} W$ & 2210 & 7.2 & 0 & pre-1990 \\
\hline $71-20$ & $70^{\circ} 04.20^{\prime} \mathrm{N}$ & $06^{\circ} 52.69^{\prime} W$ & 2005 & 7.3 & 0 & pre-1990 \\
\hline $71-25$ & $67^{\circ} 59.80^{\prime} \mathrm{N}$ & $00^{\circ} 14.00^{\prime} \mathrm{E}$ & 2850 & 9.5 & 0 & pre-1990 \\
\hline $71-22$ & $69^{\circ} 20.10^{\prime} \mathrm{N}$ & $03^{\circ} 37.09^{\prime} \mathrm{W}$ & 1833 & 9.1 & 0 & pre-1990 \\
\hline $71-28$ & $65^{\circ} 40.00^{\prime} \mathrm{N}$ & $03^{\circ} 42.49^{\prime} \mathrm{W}$ & 3140 & 8.6 & 0 & pre-1990 \\
\hline $57-14$ & $66^{\circ} 59.80^{\prime} \mathrm{N}$ & $06^{\circ} 12.30^{\prime} \mathrm{W}$ & 3005 & 8.4 & 0 & pre-1990 \\
\hline $57-12$ & $67^{\circ} 04.80^{\prime} \mathrm{N}$ & $07^{\circ} 18.79^{\prime} \mathrm{W}$ & 2093 & 8.0 & 0 & pre-1990 \\
\hline $57-10$ & $67^{\circ} 00.30^{\prime} \mathrm{N}$ & $09^{\circ} 18.49^{\prime} W$ & 1485 & 7.5 & 0 & pre-1990 \\
\hline $57-09$ & $67^{\circ} 29.89^{\prime} \mathrm{N}$ & $11^{\circ} 39.60^{\prime} \mathrm{W}$ & 1662 & 6.8 & 0 & pre-1990 \\
\hline $57-08$ & $68^{\circ} 10.30^{\prime} \mathrm{N}$ & $11^{\circ} 32.40^{\prime} \mathrm{W}$ & 1953 & 6.9 & 0 & pre-1990 \\
\hline $57-06$ & $69^{\circ} 27.19^{\prime} \mathrm{N}$ & $14^{\circ} 32.29^{\prime} \mathrm{W}$ & 1458 & 4.5 & 6.9 & pre-1990 \\
\hline $57-05$ & $69^{\circ} 08.29^{\prime} \mathrm{N}$ & $13^{\circ} 07.20^{\prime} \mathrm{W}$ & 1892 & 5.4 & 0 & pre-1990 \\
\hline $57-04$ & $68^{\circ} 31.90^{\prime} \mathrm{N}$ & $10^{\circ} 39.90^{\prime} \mathrm{W}$ & 2122 & 7.0 & 0 & pre-1990 \\
\hline $52-03$ & $62^{\circ} 12.00^{\prime} \mathrm{N}$ & $00^{\circ} 00.00^{\prime} \mathrm{E}$ & 705 & 10.7 & 0 & pre-1990 \\
\hline $52-04$ & $61^{\circ} 21.40^{\prime} \mathrm{N}$ & $03^{\circ} 21.40^{\prime} \mathrm{W}$ & 1356 & 11.4 & 0 & pre-1990 \\
\hline $52-08$ & $60^{\circ} 06.19^{\prime} \mathrm{N}$ & $08^{\circ} 05.10^{\prime} \mathrm{W}$ & 695 & 13.0 & 0 & pre-1990 \\
\hline $52-15$ & $61^{\circ} 37.90^{\prime} \mathrm{N}$ & $16^{\circ} 29.89^{\prime} \mathrm{W}$ & 2355 & 12.6 & 0 & pre-1990 \\
\hline $52-19$ & $62^{\circ} 52.69^{\prime} \mathrm{N}$ & $15^{\circ} 09.30^{\prime} \mathrm{W}$ & 1838 & 11.9 & 0 & pre-1990 \\
\hline $49 \mathrm{~A}-07$ & $62^{\circ} 56.59^{\prime} \mathrm{N}$ & $01^{\circ} 02.10^{\prime} \mathrm{E}$ & 1100 & 10.5 & 0 & pre-1990 \\
\hline $49 A-11$ & $63^{\circ} 59.29^{\prime} \mathrm{N}$ & $01^{\circ} 16.99^{\prime} \mathrm{W}$ & 2605 & 9.0 & 0 & pre-1990 \\
\hline $49 \mathrm{~A}-41$ & $63^{\circ} 04.30^{\prime} \mathrm{N}$ & $03^{\circ} 20.30^{\prime} \mathrm{E}$ & 900 & 11.3 & 0 & pre-1990 \\
\hline 49B-01 & $64^{\circ} 50.89^{\prime} \mathrm{N}$ & $07^{\circ} 42.49^{\prime} \mathrm{W}$ & 2683 & 7.4 & 0 & pre-1990 \\
\hline 49B-03 & $64^{\circ} 50.70^{\prime} \mathrm{N}$ & $01^{\circ} 31.39^{\prime} \mathrm{W}$ & 3004 & 9.5 & 0 & pre-1990 \\
\hline 49B-04 & $64^{\circ} 33.90^{\prime} \mathrm{N}$ & $00^{\circ} 43.39^{\prime} \mathrm{W}$ & 2798 & 9.7 & 0 & pre-1990 \\
\hline 49B-05 & $64^{\circ} 26.40^{\prime} \mathrm{N}$ & $00^{\circ} 23.70^{\prime} \mathrm{W}$ & 2702 & 9.8 & 0 & pre-1990 \\
\hline 49B-07 & $64^{\circ} 08.50^{\prime} \mathrm{N}$ & $00^{\circ} 23.40^{\prime} \mathrm{E}$ & 2500 & 9.8 & 0 & pre-1990 \\
\hline 49B-08 & $64^{\circ} 00.70^{\prime} \mathrm{N}$ & $00^{\circ} 43.50^{\prime} \mathrm{E}$ & 2403 & 10.0 & 0 & pre-1990 \\
\hline 49B-13 & $63^{\circ} 45.30^{\prime} \mathrm{N}$ & $01^{\circ} 23.20^{\prime} \mathrm{E}$ & 1900 & 10.0 & 0 & pre-1990 \\
\hline 49B-15 & $63^{\circ} 09.30^{\prime} \mathrm{N}$ & $02^{\circ} 49.60^{\prime} \mathrm{E}$ & 1002 & 11.1 & 0 & pre-1990 \\
\hline 49B-19 & $62^{\circ} 46.20^{\prime} \mathrm{N}$ & $03^{\circ} 43.10^{\prime} \mathrm{E}$ & 607 & 11.5 & 0 & pre-1990 \\
\hline 21291 & $78^{\circ} 00.40^{\prime} \mathrm{N}$ & $08^{\circ} 04.00^{\prime} \mathrm{E}$ & 2400 & 5.6 & 0.6 & pre-1990 \\
\hline 21292 & $77^{\circ} 59.80^{\prime} \mathrm{N}$ & $07^{\circ} 25.00^{\prime} \mathrm{E}$ & 3536 & 5.8 & 0.6 & pre-1990 \\
\hline 21293 & $77^{\circ} 59.80^{\prime} \mathrm{N}$ & $06^{\circ} 40.50^{\prime} \mathrm{E}$ & 2462 & 5.9 & 0.5 & pre-1990 \\
\hline 21294 & $78^{\circ} 00.19^{\prime} \mathrm{N}$ & $05^{\circ} 21.90^{\prime} \mathrm{E}$ & 2677 & 5.7 & 0 & pre-1990 \\
\hline 21295 & $77^{\circ} 59.80^{\prime} \mathrm{N}$ & $02^{\circ} 27.80^{\prime} \mathrm{E}$ & 3112 & 5.0 & 0 & pre-1990 \\
\hline 21296 & $78^{\circ} 00.10^{\prime} \mathrm{N}$ & $00^{\circ} 37.50^{\prime} \mathrm{E}$ & 3101 & 4.5 & 2 & pre-1990 \\
\hline 21297 & $77^{\circ} 59.80^{\prime} \mathrm{N}$ & $01^{\circ} 02.80^{\prime} \mathrm{W}$ & 3051 & 3.0 & 7.7 & pre-1990 \\
\hline 23239 & $67^{\circ} 29.80^{\prime} \mathrm{N}$ & $08^{\circ} 21.50^{\prime} \mathrm{E}$ & 1529 & 10.0 & 0 & pre-1990 \\
\hline 23054 & $67^{\circ} 39.40^{\prime} \mathrm{N}$ & $05^{\circ} 47.80^{\prime} \mathrm{E}$ & 1425 & 10.4 & 0 & pre-1990 \\
\hline 23055 & $68^{\circ} 25.20^{\prime} \mathrm{N}$ & $04^{\circ} 00.30^{\prime} \mathrm{E}$ & 2298 & 10.0 & 0 & pre-1990 \\
\hline 23056 & $68^{\circ} 30.10^{\prime} \mathrm{N}$ & $03^{\circ} 30.30^{\prime} \mathrm{E}$ & 2665 & 9.0 & 0 & pre-1990 \\
\hline 23059 & $70^{\circ} 18.40^{\prime} \mathrm{N}$ & $03^{\circ} 06.40^{\prime} \mathrm{W}$ & 2285 & 8.7 & 0 & pre-1990 \\
\hline 23065 & $68^{\circ} 30.00^{\prime} \mathrm{N}$ & $00^{\circ} 49.90^{\prime} \mathrm{E}$ & 2796 & 9.0 & 0 & pre-1990 \\
\hline 23069 & $67^{\circ} 39.90^{\prime} \mathrm{N}$ & $01^{\circ} 35.30^{\prime} \mathrm{E}$ & 1895 & 9.8 & 0 & pre-1990 \\
\hline
\end{tabular}




\begin{tabular}{|c|c|c|c|c|c|c|}
\hline Sample & Latitude & Longitude & Water depth (m) & $\mathrm{SST}\left({ }^{\circ} \mathrm{C}\right)$ & Sea ice (\%) & Sampling year \\
\hline 23071 & $67^{\circ} 05.10^{\prime} \mathrm{N}$ & $02^{\circ} 54.30^{\prime} \mathrm{E}$ & 1306 & 10.5 & 0 & pre-1990 \\
\hline 23072 & $67^{\circ} 00.10^{\prime} \mathrm{N}$ & $03^{\circ} 51.10^{\prime} \mathrm{E}$ & 1398 & 10.7 & 0 & pre-1990 \\
\hline 23074 & $66^{\circ} 40.20^{\prime} \mathrm{N}$ & $04^{\circ} 54.80^{\prime} \mathrm{E}$ & 1160 & 11.0 & 0 & pre-1990 \\
\hline 23327 & $67^{\circ} 48.30^{\prime} \mathrm{N}$ & $06^{\circ} 01.20^{\prime} \mathrm{E}$ & 1310 & 10.3 & 0 & pre-1990 \\
\hline 23334 & $68^{\circ} 40.39^{\prime} \mathrm{N}$ & $05^{\circ} 56.10^{\prime} \mathrm{E}$ & 3003 & 9.8 & 0 & pre-1990 \\
\hline 23335 & $67^{\circ} 40.39^{\prime} \mathrm{N}$ & $05^{\circ} 49.90^{\prime} \mathrm{E}$ & 1395 & 10.3 & 0 & pre-1990 \\
\hline 23337 & $70^{\circ} 03.19^{\prime} \mathrm{N}$ & $00^{\circ} 03.50^{\prime} \mathrm{E}$ & 3296 & 8.0 & 0 & pre-1990 \\
\hline 23338 & $72^{\circ} 35.70^{\prime} \mathrm{N}$ & $10^{\circ} 29.50^{\prime} \mathrm{W}$ & 2240 & 3.8 & 21.8 & pre-1990 \\
\hline 23341 & $70^{\circ} 57.00^{\prime} \mathrm{N}$ & $05^{\circ} 32.59^{\prime} \mathrm{W}$ & 1734 & 7.5 & 1.6 & pre-1990 \\
\hline 23342 & $71^{\circ} 37.80^{\prime} \mathrm{N}$ & $08^{\circ} 24.79^{\prime} \mathrm{W}$ & 1958 & 4.5 & 13.0 & pre-1990 \\
\hline 23343 & $72^{\circ} 12.79^{\prime} \mathrm{N}$ & $12^{\circ} 59.70^{\prime} \mathrm{W}$ & 2400 & 3.6 & 32.7 & pre-1990 \\
\hline 23345 & $71^{\circ} 40.09^{\prime} \mathrm{N}$ & $14^{\circ} 19.00 \mathrm{~W}$ & 1385 & 3.6 & 35.0 & pre-1990 \\
\hline 23346 & $71^{\circ} 17.50^{\prime} \mathrm{N}$ & $14^{\circ} 03.90 \mathrm{~W}$ & 1213 & 3.8 & 28.3 & pre-1990 \\
\hline 23347 & $70^{\circ} 26.20^{\prime} \mathrm{N}$ & $16^{\circ} 04.80^{\prime} \mathrm{W}$ & 1229 & 3.5 & 33.7 & pre-1990 \\
\hline 23348 & $70^{\circ} 25.09^{\prime} \mathrm{N}$ & $18^{\circ} 56.89^{\prime} \mathrm{W}$ & 729 & 1.0 & 67.8 & pre-1990 \\
\hline 23350 & $70^{\circ} 23.80^{\prime} \mathrm{N}$ & $19^{\circ} 20.80^{\prime} \mathrm{W}$ & 400 & 0.0 & 77.3 & pre-1990 \\
\hline 23351 & $70^{\circ} 21.70^{\prime} \mathrm{N}$ & $18^{\circ} 12.30^{\prime} \mathrm{W}$ & 1673 & 2.5 & 51.6 & pre-1990 \\
\hline 23352 & $70^{\circ} 00.40^{\prime} \mathrm{N}$ & $12^{\circ} 25.39^{\prime} \mathrm{W}$ & 1823 & 5.0 & 2.5 & pre-1990 \\
\hline 23353 & $70^{\circ} 34.20^{\prime} \mathrm{N}$ & $12^{\circ} 43.39^{\prime} \mathrm{W}$ & 1404 & 4.5 & 13.8 & pre-1990 \\
\hline 23354 & $70^{\circ} 19.80^{\prime} \mathrm{N}$ & $10^{\circ} 37.69^{\prime} \mathrm{W}$ & 1747 & 6.0 & 2.0 & pre-1990 \\
\hline 23359 & $65^{\circ} 31.69^{\prime} \mathrm{N}$ & $04^{\circ} 08.80 \mathrm{~W}$ & 2820 & 8.5 & 0.0 & pre-1990 \\
\hline 23295 & $71^{\circ} 08.10^{\prime} \mathrm{N}$ & $05^{\circ} 59.20^{\prime} \mathrm{W}$ & 1553 & 7.1 & 5.3 & pre-1990 \\
\hline ArkV-147 & $74^{\circ} 13.80^{\prime} \mathrm{N}$ & $10^{\circ} 02.29^{\prime} \mathrm{W}$ & 3150 & 3.0 & 23.3 & pre-1990 \\
\hline V30-103 & $52^{\circ} 46.00^{\prime} \mathrm{N}$ & $36^{\circ} 34.99^{\prime} \mathrm{W}$ & 3481 & 13.4 & 0 & pre-1990 \\
\hline V30-177 & $54^{\circ} 04.00^{\prime} \mathrm{N}$ & $24^{\circ} 10.99^{\prime} \mathrm{W}$ & 3433 & 14.3 & 0 & pre-1990 \\
\hline V30-110 & $57^{\circ} 22.00^{\prime} \mathrm{N}$ & $39^{\circ} 12.00 \mathrm{~W}$ & 3256 & 10.2 & 0 & pre-1990 \\
\hline V30-128 & $64^{\circ} 04.90^{\prime} \mathrm{N}$ & $30^{\circ} 13.00^{\prime} \mathrm{W}$ & 2310 & 10.1 & 0 & pre-1990 \\
\hline V30-130 & $67^{\circ} 30.00^{\prime} \mathrm{N}$ & $15^{\circ} 04.00 \mathrm{~W}$ & 858 & 6.8 & 0 & pre-1990 \\
\hline V30-126 & $58^{\circ} 34.00^{\prime} \mathrm{N}$ & $35^{\circ} 30.00^{\prime} \mathrm{W}$ & 2456 & 11.4 & 0 & pre-1990 \\
\hline V23-034 & $62^{\circ} 34.99^{\prime} \mathrm{N}$ & $26^{\circ} 57.00^{\prime} \mathrm{W}$ & 1414 & 11.2 & 0 & pre-1990 \\
\hline V23-083 & $49^{\circ} 52.00^{\prime} \mathrm{N}$ & $24^{\circ} 15.00^{\prime} \mathrm{W}$ & 3871 & 15.5 & 0 & pre-1990 \\
\hline RC9-228 & $52^{\circ} 32.89^{\prime} \mathrm{N}$ & $18^{\circ} 45.40^{\prime} \mathrm{W}$ & 3981 & 15.2 & 0 & pre-1990 \\
\hline ArkVI-15-63 & $75^{\circ} 31.39^{\prime} \mathrm{N}$ & $00^{\circ} 49.50^{\prime} \mathrm{E}$ & $x$ & 3.9 & 1.3 & $1990-2000$ \\
\hline 21845 & $69^{\circ} 27.60^{\prime} \mathrm{N}$ & $15^{\circ} 45.70^{\prime} \mathrm{W}$ & $x$ & 4.2 & 16.4 & $1990-2000$ \\
\hline 21878 & $73^{\circ} 15.10^{\prime} \mathrm{N}$ & $09^{\circ} 00.90 \mathrm{~W}$ & $x$ & 3.7 & 17.8 & $1990-2000$ \\
\hline 21892 & $73^{\circ} 43.99^{\prime} \mathrm{N}$ & $09^{\circ} 37.50 \mathrm{~W}$ & $x$ & 3.4 & 18.8 & $1990-2000$ \\
\hline 21893 & $74^{\circ} 52.09^{\prime} \mathrm{N}$ & $10^{\circ} 06.60^{\prime} \mathrm{W}$ & $x$ & 2.8 & 35.0 & $1990-2000$ \\
\hline 21895 & $75^{\circ} 24.79^{\prime} \mathrm{N}$ & $07^{\circ} 18.60 \mathrm{~W}$ & $x$ & 3.4 & 20.8 & $1990-2000$ \\
\hline 21900 & $74^{\circ} 31.69^{\prime} \mathrm{N}$ & $02^{\circ} 20.10^{\prime} \mathrm{W}$ & $x$ & 3.5 & 6.6 & $1990-2000$ \\
\hline 21901 & $75^{\circ} 56.59^{\prime} \mathrm{N}$ & $03^{\circ} 44.40 \mathrm{~W}$ & $x$ & 4.0 & 6.5 & $1990-2000$ \\
\hline 21905 & $76^{\circ} 55.09^{\prime} \mathrm{N}$ & $03^{\circ} 22.99^{\prime} \mathrm{W}$ & $x$ & 4.0 & 16.2 & $1990-2000$ \\
\hline 21906 & $76^{\circ} 50.50^{\prime} \mathrm{N}$ & $02^{\circ} 09.00 \mathrm{~W}$ & $x$ & 4.2 & 9.1 & $1990-2000$ \\
\hline 21908 & $76^{\circ} 19.30^{\prime} \mathrm{N}$ & $01^{\circ} 04.30 \mathrm{~W}$ & $x$ & 4.2 & 2.7 & $1990-2000$ \\
\hline 21909 & $76^{\circ} 06.30^{\prime} \mathrm{N}$ & $01^{\circ} 00.30 \mathrm{~W}$ & $x$ & 4.0 & 2.2 & $1990-2000$ \\
\hline 21910 & $75^{\circ} 37.00^{\prime} \mathrm{N}$ & $01^{\circ} 19.00^{\prime} \mathrm{E}$ & $x$ & 3.9 & 1.3 & $1990-2000$ \\
\hline 21911 & $75^{\circ} 03.49^{\prime} \mathrm{N}$ & $02^{\circ} 58.50^{\prime} \mathrm{E}$ & $x$ & 3.8 & 1.3 & $1990-2000$ \\
\hline 21912 & $74^{\circ} 34.50^{\prime} \mathrm{N}$ & $02^{\circ} 54.50^{\prime} \mathrm{E}$ & $x$ & 3.9 & 3.2 & $1990-2000$ \\
\hline 23254 & $73^{\circ} 03.30^{\prime} \mathrm{N}$ & $09^{\circ} 44.60^{\prime} \mathrm{E}$ & $x$ & 6.8 & 0 & $1990-2000$ \\
\hline
\end{tabular}




\begin{tabular}{|c|c|c|c|c|c|c|}
\hline Sample & Latitude & Longitude & Water depth (m) & $\mathrm{SST}\left({ }^{\circ} \mathrm{C}\right)$ & Sea ice (\%) & Sampling year \\
\hline 23257 & $74^{\circ} 52.80^{\prime} \mathrm{N}$ & $11^{\circ} 08.29^{\prime} \mathrm{E}$ & $x$ & 6.0 & 0 & $1990-2000$ \\
\hline 23258 & $74^{\circ} 59.80^{\prime} \mathrm{N}$ & $13^{\circ} 57.49^{\prime} \mathrm{E}$ & $x$ & 7.0 & 0.4 & $1990-2000$ \\
\hline 23259 & $72^{\circ} 02.10^{\prime} \mathrm{N}$ & $09^{\circ} 15.90^{\prime} \mathrm{E}$ & $x$ & 7.2 & 0 & $1990-2000$ \\
\hline 23260 & $72^{\circ} 08.20^{\prime} \mathrm{N}$ & $11^{\circ} 27.10^{\prime} \mathrm{E}$ & $x$ & 8.0 & 0 & $1990-2000$ \\
\hline 23264 & $71^{\circ} 12.19^{\prime} \mathrm{N}$ & $15^{\circ} 49.99^{\prime} \mathrm{E}$ & $x$ & 9.0 & 0 & $1990-2000$ \\
\hline 23269 & $71^{\circ} 26.29^{\prime} \mathrm{N}$ & $00^{\circ} 39.80^{\prime} \mathrm{E}$ & $x$ & 7.5 & 0 & $1990-2000$ \\
\hline 23289 & $72^{\circ} 22.60^{\prime} \mathrm{N}$ & $01^{\circ} 48.00^{\prime} \mathrm{E}$ & $x$ & 6.9 & 0.7 & $1990-2000$ \\
\hline 23297 & $70^{\circ} 00.70^{\prime} \mathrm{N}$ & $00^{\circ} 04.80^{\prime} \mathrm{E}$ & $x$ & 8.0 & 0 & $1990-2000$ \\
\hline HU91-45-18 & $55^{\circ} 02.59^{\prime} \mathrm{N}$ & $52^{\circ} 07.80^{\prime} \mathrm{W}$ & $x$ & 8.2 & 1.5 & $1990-2000$ \\
\hline HU91-45-28 & $56^{\circ} 36.90^{\prime} \mathrm{N}$ & $49^{\circ} 45.00^{\prime} \mathrm{W}$ & $x$ & 8.8 & 0 & $1990-2000$ \\
\hline HU91-45-51 & $59^{\circ} 29.59^{\prime} \mathrm{N}$ & $39^{\circ} 18.40^{\prime} \mathrm{W}$ & $x$ & 10.4 & 0 & $1990-2000$ \\
\hline HU91-45-56 & $59^{\circ} 38.10^{\prime} \mathrm{N}$ & $36^{\circ} 07.50^{\prime} \mathrm{W}$ & $x$ & 11.3 & 0 & $1990-2000$ \\
\hline Hu91-45-60 & $59^{\circ} 50.89^{\prime} \mathrm{N}$ & $33^{\circ} 34.90^{\prime} \mathrm{W}$ & $x$ & 12.1 & 0 & $1990-2000$ \\
\hline HU91-45-71 & $58^{\circ} 56.40^{\prime} \mathrm{N}$ & $28^{\circ} 44.40^{\prime} \mathrm{W}$ & $x$ & 13.1 & 0 & $1990-2000$ \\
\hline HU91-45-80 & $53^{\circ} 03.40^{\prime} \mathrm{N}$ & $33^{\circ} 31.80^{\prime} \mathrm{W}$ & $x$ & 13.7 & 0 & $1990-2000$ \\
\hline HU91-45-90 & $53^{\circ} 19.80^{\prime} \mathrm{N}$ & $45^{\circ} 15.60^{\prime} \mathrm{W}$ & $x$ & 11.2 & 0 & $1990-2000$ \\
\hline HU91-45-93 & $50^{\circ} 12.30^{\prime} \mathrm{N}$ & $45^{\circ} 41.20^{\prime} \mathrm{W}$ & $x$ & 9.0 & 0 & $1990-2000$ \\
\hline SU90-I-03 & $51^{\circ} 52.69^{\prime} \mathrm{N}$ & $39^{\circ} 46.80^{\prime} \mathrm{W}$ & $x$ & 13.4 & 0 & $1990-2000$ \\
\hline SU90-I-04 & $58^{\circ} 12.60^{\prime} \mathrm{N}$ & $45^{\circ} 12.30^{\prime} \mathrm{W}$ & $x$ & 8.1 & 0 & $1990-2000$ \\
\hline SU90-I-06 & $59^{\circ} 31.50^{\prime} \mathrm{N}$ & $39^{\circ} 27.10^{\prime} \mathrm{W}$ & $x$ & 10.3 & 0 & $1990-2000$ \\
\hline SU90-I-08 & $60^{\circ} 03.49^{\prime} \mathrm{N}$ & $22^{\circ} 00.49^{\prime} W$ & $x$ & 13.2 & 0 & $1990-2000$ \\
\hline SU90-I-09 & $55^{\circ} 57.00^{\prime} \mathrm{N}$ & $20^{\circ} 19.00^{\prime} \mathrm{W}$ & $x$ & 14.6 & 0 & $1990-2000$ \\
\hline SU90-I-10 & $52^{\circ} 34.00^{\prime} \mathrm{N}$ & $21^{\circ} 55.99^{\prime} W$ & $x$ & 15.2 & 0 & $1990-2000$ \\
\hline SU90-06 & $42^{\circ} 01.80^{\prime} \mathrm{N}$ & $32^{\circ} 42.70^{\prime} \mathrm{W}$ & $x$ & 19.7 & 0 & $1990-2000$ \\
\hline SU90-08 & $43^{\circ} 31.20^{\prime} \mathrm{N}$ & $30^{\circ} 24.49^{\prime} W$ & $x$ & 18.9 & 0 & $1990-2000$ \\
\hline SU90-20 & $59^{\circ} 51.70^{\prime} \mathrm{N}$ & $39^{\circ} 39.79^{\prime} \mathrm{W}$ & $x$ & 10.2 & 0 & $1990-2000$ \\
\hline SU-90-21 & $60^{\circ} 17.10^{\prime} \mathrm{N}$ & $40^{\circ} 13.09^{\prime} \mathrm{W}$ & $x$ & 10.0 & 0 & $1990-2000$ \\
\hline SU90-22 & $62^{\circ} 32.50^{\prime} \mathrm{N}$ & $38^{\circ} 49.99^{\prime} W$ & $x$ & 9.2 & 0 & $1990-2000$ \\
\hline SU90-25 & $62^{\circ} 54.60^{\prime} \mathrm{N}$ & $32^{\circ} 10.80^{\prime} \mathrm{W}$ & $x$ & 11.2 & 0 & $1990-2000$ \\
\hline SU90-27 & $62^{\circ} 35.89^{\prime} \mathrm{N}$ & $28^{\circ} 21.40^{\prime} \mathrm{W}$ & $x$ & 11.1 & 0 & $1990-2000$ \\
\hline SU90-30 & $64^{\circ} 39.90^{\prime} \mathrm{N}$ & $30^{\circ} 10.60^{\prime} \mathrm{W}$ & $x$ & 10.0 & 0 & $1990-2000$ \\
\hline SU90-34 & $57^{\circ} 33.10^{\prime} \mathrm{N}$ & $21^{\circ} 09.60^{\prime} W$ & $x$ & 14.2 & 0 & $1990-2000$ \\
\hline SU90-35 & $57^{\circ} 34.20^{\prime} \mathrm{N}$ & $20^{\circ} 50.20^{\prime} \mathrm{W}$ & $x$ & 14.3 & 0 & $1990-2000$ \\
\hline SU90-38 & $54^{\circ} 05.40^{\prime} \mathrm{N}$ & $21^{\circ} 04.90^{\prime} \mathrm{W}$ & $x$ & 14.8 & 0 & $1990-2000$ \\
\hline SU90-40 & $51^{\circ} 43.09^{\prime} \mathrm{N}$ & $21^{\circ} 52.69^{\prime} W$ & $x$ & 15.3 & 0 & $1990-2000$ \\
\hline SU90-41 & $51^{\circ} 43.30^{\prime} \mathrm{N}$ & $21^{\circ} 52.39^{\prime} W$ & $x$ & 15.3 & 0 & $1990-2000$ \\
\hline SU90-43 & $50^{\circ} 17.29^{\prime} \mathrm{N}$ & $19^{\circ} 17.89^{\prime} \mathrm{W}$ & $x$ & 15.7 & 0 & $1990-2000$ \\
\hline SU90-44 & $50^{\circ} 06.19^{\prime} \mathrm{N}$ & $17^{\circ} 54.60^{\prime} \mathrm{W}$ & $x$ & 15.8 & 0 & $1990-2000$ \\
\hline HU90-13-11 & $58^{\circ} 54.90^{\prime} \mathrm{N}$ & $47^{\circ} 05.10^{\prime} \mathrm{W}$ & $x$ & 7.4 & 0 & $1990-2000$ \\
\hline HU90-13-17 & $58^{\circ} 12.49^{\prime} \mathrm{N}$ & $48^{\circ} 21.60^{\prime} \mathrm{W}$ & $x$ & 8.0 & 0 & $1990-2000$ \\
\hline HU90-13-20 & $58^{\circ} 21.60^{\prime} \mathrm{N}$ & $54^{\circ} 27.40^{\prime} \mathrm{W}$ & $x$ & 4.9 & 0.7 & $1990-2000$ \\
\hline JM 06-WP-19-MC & $78^{\circ} 00.77^{\prime} \mathrm{N}$ & $02^{\circ} 30.17^{\prime} W$ & 2859 & 2.0 & 21.8 & 2006 \\
\hline JM 06-WP-21-MC & $77^{\circ} 00.20^{\prime} \mathrm{N}$ & $03^{\circ} 23.66^{\prime} \mathrm{W}$ & 1779 & 2.5 & 15.2 & 2006 \\
\hline JM 06-WP-24-MC & $74^{\circ} 37.99^{\prime} \mathrm{N}$ & $11^{\circ} 11.20^{\prime} \mathrm{W}$ & 2974 & 1.7 & 33.9 & 2006 \\
\hline JM 06-WP-26-MC & $74^{\circ} 53.49^{\prime} \mathrm{N}$ & $10^{\circ} 46.09^{\prime} \mathrm{W}$ & 3064 & 2.0 & 45.8 & 2006 \\
\hline JM 06-WP-07-BC & $78^{\circ} 52.62^{\prime} \mathrm{N}$ & $07^{\circ} 20.45^{\prime} \mathrm{W}$ & 1181 & 4.1 & 0 & 2006 \\
\hline JM 06-WP-12-BC & $78^{\circ} 54.46^{\prime} \mathrm{N}$ & $02^{\circ} 24.91^{\prime} \mathrm{E}$ & 2426 & 2.7 & 10.7 & 2006 \\
\hline JM 06-WP-10-BC & $78^{\circ} 56.17^{\prime} \mathrm{N}$ & $05^{\circ} 24.07^{\prime} \mathrm{E}$ & 2483 & 3.6 & 0 & 2006 \\
\hline
\end{tabular}




\begin{tabular}{|c|c|c|c|c|c|c|}
\hline Sample & Latitude & Longitude & Water depth (m) & $\mathrm{SST}\left({ }^{\circ} \mathrm{C}\right)$ & Sea ice (\%) & Sampling year \\
\hline JM 06-W P-16-MC & $78^{\circ} 53.76^{\prime} \mathrm{N}$ & $00^{\circ} 16.91^{\prime} \mathrm{E}$ & 2546 & 2.1 & 33.8 & 2006 \\
\hline JM 06-WP-14-BC & $78^{\circ} 55.88^{\prime} \mathrm{N}$ & $01^{\circ} 06.46^{\prime} \mathrm{E}$ & 2502 & 2.4 & 24.2 & 2006 \\
\hline JM 07-WP-182 MC & $77^{\circ} 30.54^{\prime} \mathrm{N}$ & $00^{\circ} 02.26^{\prime} \mathrm{W}$ & 3100 & 2.6 & 1.9 & 2007 \\
\hline JM 07-WP-180 MC & $77^{\circ} 28.60^{\prime} \mathrm{N}$ & $02^{\circ} 02.53^{\prime} \mathrm{W}$ & 3029 & 2.0 & 11.8 & 2007 \\
\hline JM 07-WP-176 MC & $69^{\circ} 51.58^{\prime} \mathrm{N}$ & $22^{\circ} 07.90^{\prime} \mathrm{W}$ & 482 & 1.4 & 80.1 & 2007 \\
\hline JM 07-WP-170 MC & $73^{\circ} 44.87^{\prime} \mathrm{N}$ & $14^{\circ} 11.95^{\prime} \mathrm{W}$ & 2285 & 1.3 & 59.5 & 2007 \\
\hline JM 07-WP-171 MC & $73^{\circ} 46.13^{\prime} \mathrm{N}$ & $13^{\circ} 00.60^{\prime} \mathrm{W}$ & 2570 & 1.6 & 41.8 & 2007 \\
\hline JM 07-WP-172 MC & $73^{\circ} 47.08^{\prime} \mathrm{N}$ & $12^{\circ} 21.64^{\prime} \mathrm{W}$ & 2742 & 2.0 & 35.4 & 2007 \\
\hline JM 08-WP-337-MC & $78^{\circ} 08.13^{\prime} \mathrm{N}$ & $08^{\circ} 30.41^{\prime} \mathrm{E}$ & 1733 & 4.5 & 0 & 2008 \\
\hline JM 08-WP-338-MC & $78^{\circ} 10.02^{\prime} \mathrm{N}$ & $06^{\circ} 32.73^{\prime} \mathrm{E}$ & 1766 & 3.9 & 0.5 & 2008 \\
\hline JM 08-WP-339-MC & $77^{\circ} 59.73^{\prime} \mathrm{N}$ & $05^{\circ} 58.35^{\prime} \mathrm{E}$ & 2343 & 4.4 & 0.3 & 2008 \\
\hline JM 08-WP-341-MC & $77^{\circ} 59.71^{\prime} \mathrm{N}$ & $04^{\circ} 07.44^{\prime} \mathrm{E}$ & 2952 & 4.2 & 0 & 2008 \\
\hline JM 08-WP-344-MC & $75^{\circ} 58.93^{\prime} \mathrm{N}$ & $08^{\circ} 19.38^{\prime} \mathrm{E}$ & 2288 & 6.4 & 0 & 2008 \\
\hline JM 08-WP-345-MC & $75^{\circ} 59.68^{\prime} \mathrm{N}$ & $11^{\circ} 00.10^{\prime} \mathrm{E}$ & 2184 & 6.6 & 0 & 2008 \\
\hline JM 08-WP-348-MC & $75^{\circ} 59.73^{\prime} \mathrm{N}$ & $13^{\circ} 17.89^{\prime} \mathrm{E}$ & 1264 & 6.3 & 2.4 & 2008 \\
\hline JM 08-WP-350-MC & $76^{\circ} 47.88^{\prime} \mathrm{N}$ & $01^{\circ} 458.80^{\prime} \mathrm{E}$ & 245 & 5.4 & 33 & 2008 \\
\hline HU2008-029-002 & $61^{\circ} 27.82^{\prime} \mathrm{N}$ & $58^{\circ} 02.15^{\prime} \mathrm{W}$ & 2668 & 6.4 & 19.5 & 2008 \\
\hline HU2008-029-006 & $64^{\circ} 23.58^{\prime} \mathrm{N}$ & $58^{\circ} 08.08^{\prime} \mathrm{W}$ & 857 & 4.6 & 62.7 & 2008 \\
\hline HU2008-029-010 & $68^{\circ} 39.99^{\prime} \mathrm{N}$ & $59^{\circ} 59.99^{\prime} \mathrm{W}$ & 1479 & 3.3 & 96 & 2008 \\
\hline HU2008-029-014 & $70^{\circ} 27.70^{\prime} \mathrm{N}$ & $64^{\circ} 39.44^{\prime} \mathrm{W}$ & 2060 & 2.9 & 97.8 & 2008 \\
\hline HU2008-029-019 & $75^{\circ} 28.12^{\prime} \mathrm{N}$ & $70^{\circ} 38.07^{\prime} \mathrm{W}$ & 602 & 2.8 & 94.5 & 2008 \\
\hline HU2008-029-028 & $76^{\circ} 58.73^{\prime N} \mathrm{~N}$ & $71^{\circ} 53.43^{\prime} \mathrm{W}$ & 1048 & 2.4 & 80.3 & 2008 \\
\hline HU2008-029-032 & $76^{\circ} 19.72^{\prime} \mathrm{N}$ & $71^{\circ} 25.26^{\prime} \mathrm{W}$ & 696 & 2.4 & 84.3 & 2008 \\
\hline HU2008-029-036 & $76^{\circ} 34.38^{\prime} \mathrm{N}$ & $73^{\circ} 57.32^{\prime} \mathrm{W}$ & 680 & 2.2 & 82.4 & 2008 \\
\hline HU2008-029-040 & $75^{\circ} 34.76^{\prime} \mathrm{N}$ & $78^{\circ} 37.77^{\prime} \mathrm{W}$ & 580 & 3.3 & 78.8 & 2008 \\
\hline HU2008-029-047 & $74^{\circ} 01.39^{\prime} \mathrm{N}$ & $77^{\circ} 06.97^{\prime} \mathrm{W}$ & 870 & 3.4 & 97.8 & 2008 \\
\hline HU2008-029-055 & $74^{\circ} 05.52^{\prime} \mathrm{N}$ & $78^{\circ} 43.11^{\prime} \mathrm{W}$ & 866 & 3.4 & 95.9 & 2008 \\
\hline HU2008-029-063 & $72^{\circ} 24.38^{\prime} \mathrm{N}$ & $67^{\circ} 43.00^{\prime} \mathrm{W}$ & 2375 & 2.9 & 99.1 & 2008 \\
\hline HU2008-029-068 & $68^{\circ} 13.68^{\prime} \mathrm{N}$ & $57^{\circ} 37.08^{\prime} \mathrm{W}$ & 437 & 4.0 & 89 & 2008 \\
\hline KG2 & $65^{\circ} 59.97^{\prime} \mathrm{N}$ & $60^{\circ} 29.97^{\prime} \mathrm{W}$ & 393 & 2.8 & 86.9 & 2008 \\
\hline MC688 & $62^{\circ} 32.58^{\prime} \mathrm{N}$ & $52^{\circ} 37.92^{\prime} \mathrm{W}$ & 2634 & 5.1 & 0 & 2008 \\
\hline MC690 & $68^{\circ} 58.12^{\prime} \mathrm{N}$ & $59^{\circ} 34.38^{\prime} \mathrm{W}$ & 1339 & 3.3 & 94.8 & 2008 \\
\hline MC691 & $72^{\circ} 30.37^{\prime} \mathrm{N}$ & $61^{\circ} 57.34^{\prime} \mathrm{W}$ & 1215 & 3.0 & 98.2 & 2008 \\
\hline MC692 & $71^{\circ} 25.53^{\prime} \mathrm{N}$ & $70^{\circ} 26.40^{\prime} \mathrm{W}$ & 798 & 3.4 & 99 & 2008 \\
\hline MC693 & $68^{\circ} 50.29^{\prime} \mathrm{N}$ & $66^{\circ} 16.26^{\prime} \mathrm{W}$ & 865 & 3.1 & 91.3 & 2008 \\
\hline MC694 & $68^{\circ} 31.87^{\prime} \mathrm{N}$ & $68^{\circ} 19.83^{\prime} \mathrm{W}$ & 1550 & 3.3 & 0 & 2008 \\
\hline MC695 & $64^{\circ} 59.98^{\prime} \mathrm{N}$ & $59^{\circ} 00.03^{\prime} \mathrm{W}$ & 467 & 4.2 & 80 & 2008 \\
\hline MC696 & $64^{\circ} 38.40^{\prime} \mathrm{N}$ & $57^{\circ} 59.95^{\prime} \mathrm{W}$ & 1009 & 5.6 & 48.9 & 2008 \\
\hline MC697 & $62^{\circ} 33.16^{\prime} \mathrm{N}$ & $56^{\circ} 28.08^{\prime} W$ & 2329,5 & 6.4 & 17.6 & 2008 \\
\hline
\end{tabular}

